\title{
Ground-Water, Surface-Water, and Water- Chemistry Data, Black Mesa Area, Northeastern Arizona-2000-2001, and Performance and Sensitivity of the 1988 USGS Numerical Model of the N Aquifer
}

Water-Resources Investigations Report 02-4211
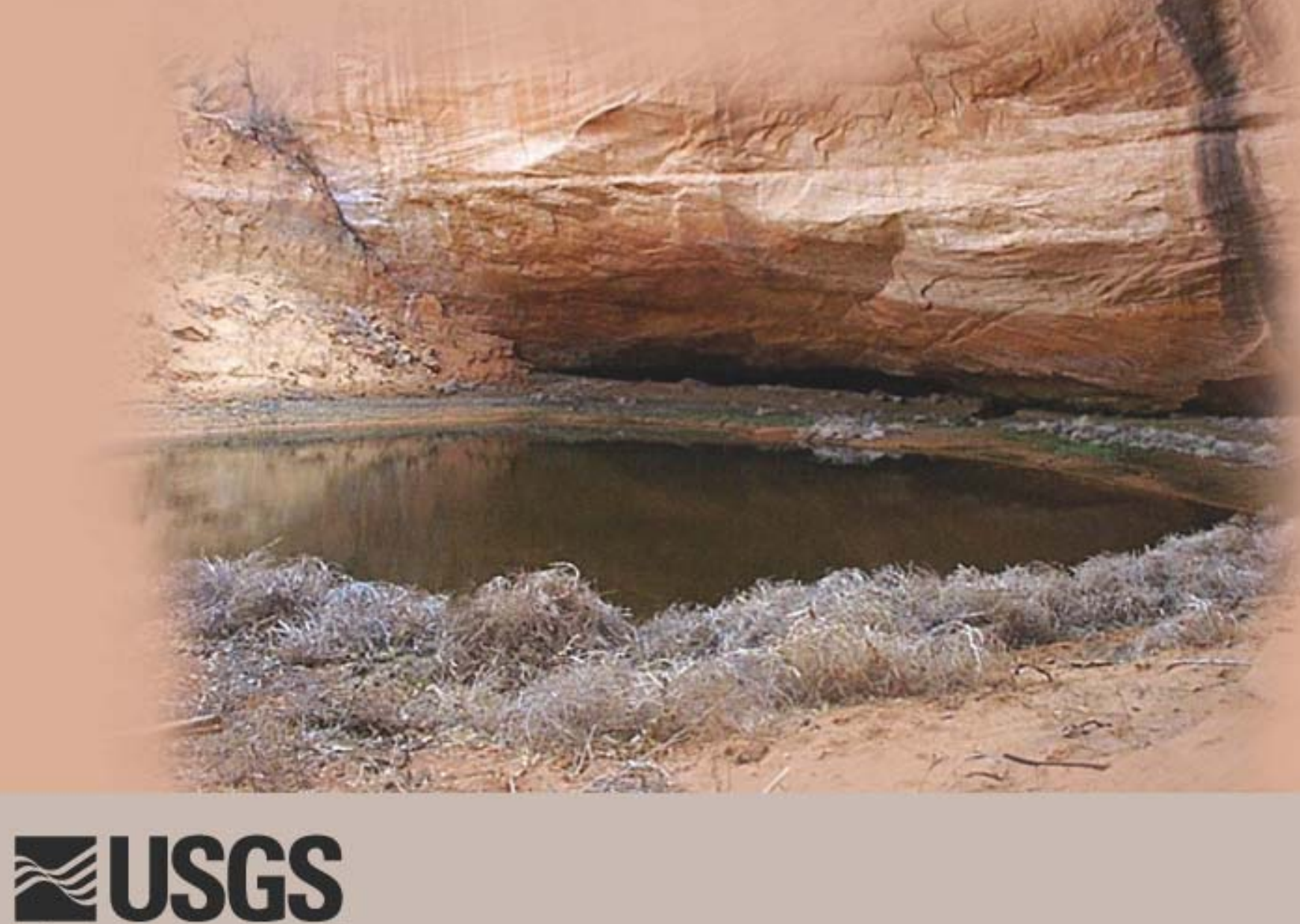


\section{Ground-Water, Surface-Water, and Water-Chemistry Data, Black Mesa Area, Northeastern Arizona- 2000-2001, and Performance and Sensitivity of the 1988 USGS Numerical Model of the N Aquifer}

Water-Resources Investigations Report 02—4211

Prepared in cooperation with the

ARIZONA DEPARTMENT OF WATER RESOURCES and BUREAU OF INDIAN AFFAIRS 


\section{U.S. DEPARTMENT OF THE INTERIOR \\ GALE A. NORTON, Secretary}

U.S. GEOLOGICAL SURVEY

Charles G. Groat, Director

The use of firm, trade, and brand names in this report is for identification purposes only and does not constitute endorsement by the U.S. Geological Survey.

For additional information write to:

District Chief

U.S. Geological Survey

Water Resources Division

520 N. Park Avenue, Suite 221

Tucson, AZ 85719-5035
Copies of this report can be purchased from:

U.S. Geological Survey

Information Services

Box 25286

Federal Center

Denver, C0 80225-0046

Information about U.S. Geological Survey programs in Arizona is available online at http://az.water.usgs.gov. 


\section{CONTENTS}

Abstract

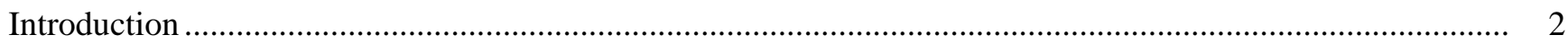

Purpose and scope

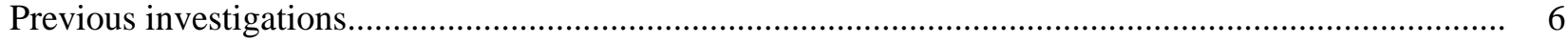

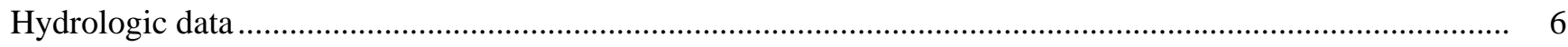

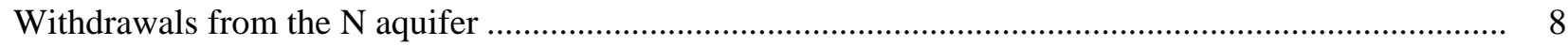

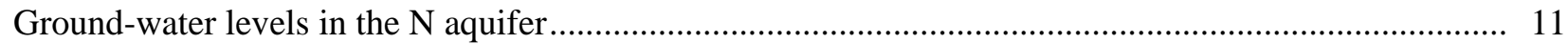

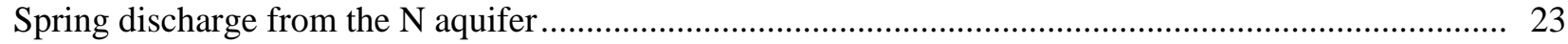

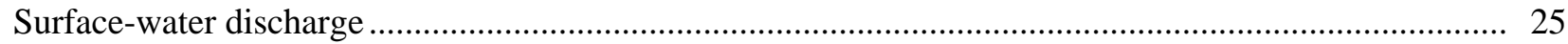

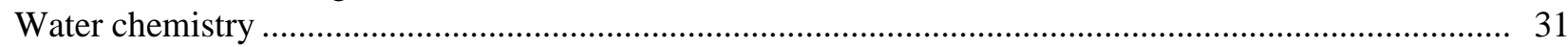

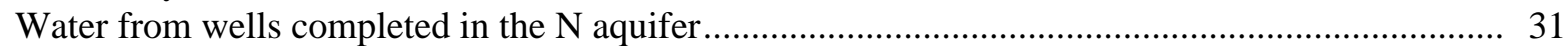

Water from springs that discharge from the $\mathrm{N}$ aquifer ............................................................ 38

Performance and sensitivity of the 1988 USGS numerical model of the $\mathrm{N}$ aquifer ................................... 38

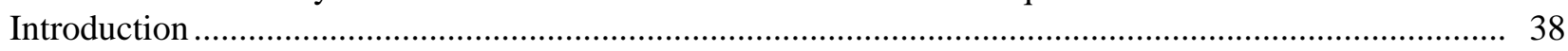

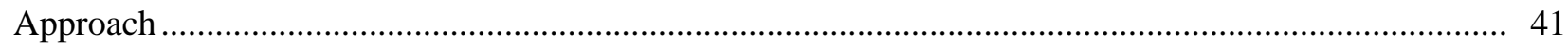

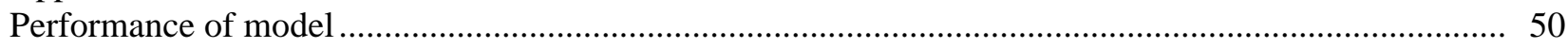

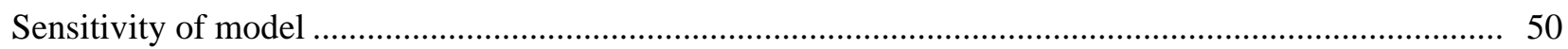

Potential revisions, new data, and studies to improve the model....................................................... 68

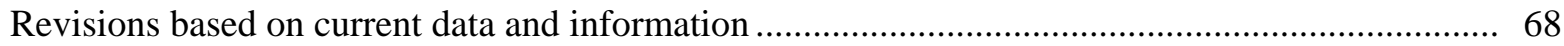

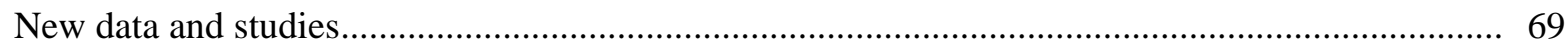

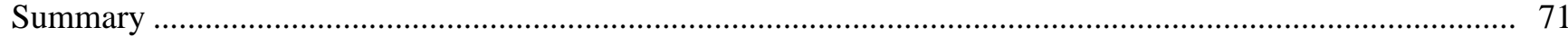

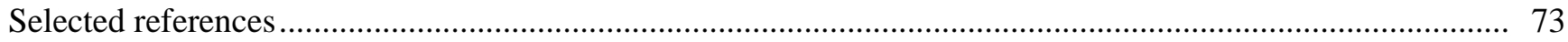




\section{FIGURES}

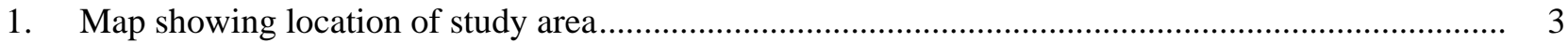

2. Diagram showing rock formations and hydrogeologic units of the Black Mesa area, Arizona.......... 4

3. Graph showing withdrawals from the $\mathrm{N}$ aquifer, Black Mesa area, Arizona, 1965-2000................. 8

4. Map showing locations of well systems monitored for withdrawals from the $\mathrm{N}$ aquifer, Black Mesa area, Arizona, 2000 ........................................................................................... 9

5. Map showing water-level changes in $\mathrm{N}$-aquifer wells from the prestress period (prior to 1965) to 2001, Black Mesa area, Arizona....

6. Graph showing annual water-level changes for observation wells completed in the $\mathrm{N}$ aquifer, Black Mesa area, Arizona, 1983-2001

7. Hydrographs showing observed water-level changes, 1950-2001, and simulated water-level changes, 1965-99, for annual observation-well network, Black Mesa area, Arizona

8. Hydrographs showing observed water-level changes in continuous-record observation wells, BM1-BM6, 1963-2001, and simulated water-level changes 1965-99, Black Mesa area, Arizona.

9. Map showing surface-water and water-chemistry data-collection sites, Black Mesa area, Arizona, 2000-2001

10. Graphs showing annual precipitation at Betatakin, Arizona, and streamflow characteristics at Moenkopi Wash (09401260), Laguna Creek (09379180), Dinnebito Wash (09401110), and Polacca Wash (09400568), Black Mesa area, Arizona:

A. Annual average precipitation at Betatakin, Arizona, calendar years 1976-2000...................... 30

B. Annual average discharge for calendar years 1977-2000 ................................................... 30

C. Median discharge for November, December, January, and February for water years 1977-2000.

11. Trilinear diagram showing relative chemical compositions of ground water from the $\mathrm{N}$ aquifer, Black Mesa area, Arizona, 2001

12. Map showing water chemistry and distribution of dissolved solids in the $\mathrm{N}$ aquifer, Black Mesa area, Arizona, 2001

13. Graph showing dissolved-solids concentrations in water from wells Forest Lake NTUA 1, Kayenta PM2, Keams Canyon PM2, Kykotsmovi PM2, Rough Rock PM5, and Peabody 4, Black Mesa area, Arizona, 1980-2001.

14. Map showing grid for 1988 USGS model of the $\mathrm{N}$ aquifer and boundary conditions used to simulate ground-water recharge, Black Mesa area, Arizona

15. Map showing boundary of 1988 USGS model of the $\mathrm{N}$ aquifer and boundary conditions used to simulate ground-water discharge, Black Mesa area, Arizona.....

16. Map showing distribution of hydraulic conductivity used in the 1988 USGS model of the $\mathrm{N}$ aquifer, Black Mesa area, Arizona

17. Map showing distribution of transmissivity used in the 1988 USGS model of the N aquifer, Black Mesa area, Arizona.

18. Map showing locations of observation wells used in the performance and sensitivity analysis of the 1988 USGS model of the $\mathrm{N}$ aquifer, Black Mesa area, Arizona. 
19. Graphs showing relations between residuals and simulated values, Black Mesa area, Arizona:

A. Steady-state heads 55

B. Changes in head from steady state to 1999

20. Map showing residuals for steady-state heads and simulated steady-state potentiometric surface, Black Mesa area, Arizona

21. Map showing residuals for changes in head from steady state to 1999, Black Mesa area, Arizona.....

22. Graph showing relation between residuals for changes in heads and year of simulation, Black Mesa area, Arizona.

23. Graphs showing composite scaled sensitivities for model parameters:
A. Based on all observations 60
B. Based on steady-state heads 60
C. Based on transient changes in heads 60
D. Based on flows (ground-water discharge)

24. Maps showing one-percent scaled sensitivity of steady-state heads for transmissivity, recharge, river conductance, and drain conductance, Black Mesa area, Arizona

25. Maps showing one-percent scaled sensitivity of changes in head from steady state to 1999 for transmissivity, storage coefficient, recharge, and river conductance, 


\section{TABLES}

1. Withdrawals from the $\mathrm{N}$ aquifer, Black Mesa area, Arizona, 1965-2000 .................................... 5

2. Identification numbers and names of study wells, Black Mesa area, Arizona.................................. 7

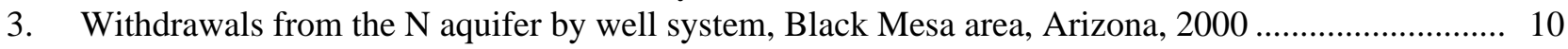

4. Water-level changes in wells completed in the $\mathrm{N}$ aquifer, Black Mesa area, Arizona, prestress period to 2001

5. Well-construction characteristics, top of $\mathrm{N}$ aquifer, and type of data collected for wells in monitoring program, Black Mesa area, Arizona, 2000-2001 . 14

6. Discharge measurements of selected springs, Black Mesa area, Arizona, 1952-2001 .................... 23

7. Discharge data, Moenkopi Wash at Moenkopi, Arizona (09401260), calendar year 2000 ............... 26

8. Discharge data, Laguna Creek at Dennehotso, Arizona (09379180), calendar year 2000................. 27

9. Discharge data, Dinnebito Wash near Sand Springs, Arizona (09401110), calendar year 2000 ........ 28

10. Discharge data, Polacca Wash near Second Mesa, Arizona (09400568), calendar year 2000 ........... 29

11. Date that data collection began and drainage areas for streamflow-gaging stations, Black Mesa area, Arizona...

12. Physical properties and chemical analyses of water from selected industrial and municipal wells completed in the $\mathrm{N}$ aquifer, Black Mesa area, Arizona, 2001 .....

13. Specific conductance and concentrations of selected chemical constituents in water from industrial and municipal wells completed in the $\mathrm{N}$ aquifer, Black Mesa area, Arizona, 1968-2001

14. Physical properties and chemical analyses of water from selected springs that discharge from the $\mathrm{N}$ aquifer, Black Mesa area, Arizona, 2001

15. Specific conductance and concentrations of selected chemical constituents in water from selected springs that discharge from the N aquifer, Black Mesa area, Arizona, 1948-2001

16. Observation data used in the 1988 USGS model of the $\mathrm{N}$ aquifer and in the analysis of the 1988 model for this report, Black Mesa area, Arizona...

17. Summary of residuals for steady-state heads and changes in heads from steady state to 1999, Black Mesa area, Arizona

18. Observed heads, simulated heads, and head residuals for steady-state simulation, Black Mesa area, Arizona.

19. Summary of residuals for observed (estimated) and simulated flows, Black Mesa area, Arizona

20. Observed and simulated changes in head from steady state to 1999 , and residuals for changes in head, Black Mesa area, Arizona...

21. Correlation matrices for parameters in steady-state simulations, Black Mesa area, Arizona

22. Correlation matrices for parameters in steady-state and transient simulations, Black Mesa area, Arizona.

23. The most important wells in terms of sensitivity of changes in heads from steady state to 1999 , for transmissivity and storage coefficient, Black Mesa area, Arizona... 
CONVERSION FACTORS AND DATUMS

\begin{tabular}{lcl}
\hline Multiply & \multicolumn{1}{c}{ By } & To obtain \\
\hline inch (in) & 2.54 & centimeter \\
inch (in) & 25.4 & millimeter \\
foot (ft) & 0.3048 & meter \\
mile (mi) & 1.609 & kilometer \\
square mile $\left(\mathrm{mi}^{2}\right)$ & 2.590 & square kilometer \\
acre-foot $(\mathrm{acre}-\mathrm{ft})$ & 0.001233 & cubic hectometer \\
cubic foot per second $(\mathrm{ft} / \mathrm{s})$ & 0.02832 & cubic meter per second \\
gallon per minute $(\mathrm{gal} / \mathrm{min})$ & 0.06309 & liter per second \\
gallon per day $(\mathrm{gal} / \mathrm{d})$ & 0.003785 & cubic meter per day \\
\hline
\end{tabular}

Temperature in degrees Celsius $\left({ }^{\circ} \mathrm{C}\right)$ may be converted to degrees Fahrenheit $\left({ }^{\circ} \mathrm{F}\right)$ as follows:

$$
{ }^{\circ} \mathrm{F}=\left(1.8^{\circ} \mathrm{C}\right)+32
$$

Vertical coordinate information is referenced to the National Geodetic Vertical Datum of 1929 (NGVD 29)-a geodetic datum derived from a general adjustment of the first-order level nets of both the United States and Canada, formerly called Sea Level Datum of 1929; horizontal coordinate information is referenced to the North American Datum of 1927 (NAD 27). Altitude, as used in this report, refers to distance above or below NGVD 29.

\section{ABBREVIATED WATER-QUALITY UNITS}

Chemical concentration and water temperature are given only in metric units. Chemical concentration in water is given in milligrams per liter $(\mathrm{mg} / \mathrm{L})$ or micrograms per liter $(\mu \mathrm{g} / \mathrm{L})$. Milligrams per liter is a unit expressing the solute mass (milligrams) per unit volume (liter) of water. One thousand micrograms per liter is equivalent to 1 milligram per liter. For concentrations less than 7,000 milligrams per liter, the numerical value is about the same as for concentrations in parts per million. Specific conductance is given in microsiemens per centimeter at 25 degrees Celsius $\left(\mu \mathrm{S} / \mathrm{cm}\right.$ at $\left.25^{\circ} \mathrm{C}\right)$. 


\title{
Ground-Water, Surface-Water, and Water-Chemistry Data, Black Mesa Area, Northeastern Arizona-2000-2001, and Performance and Sensitivity of the 1988 USGS Numerical Model of the $\mathrm{N}$ aquifer
}

\author{
By Blakemore E. Thomas
}

\begin{abstract}
The $\mathrm{N}$ aquifer is the major source of water in the 5,400-square-mile area of Black Mesa in northeastern Arizona. Availability of water is an important issue in this area because of continued industrial and municipal use, a growing population, and precipitation of about 6 to 14 inches per year.

The monitoring program in Black Mesa has been operating since 1971 and is designed to determine the long-term effects of ground-water withdrawals from the $\mathrm{N}$ aquifer for industrial and municipal uses. The monitoring program includes measurements of (1) ground-water pumping, (2) ground-water levels, (3) spring discharge, (4) surface-water discharge, and (5) ground-water chemistry.

In 2000, total ground-water withdrawals were 7,740 acre-feet, industrial use was 4,490 acre-feet, and municipal use was 3,250 acre-feet. From 1999 to 2000, total withdrawals increased by 9 percent, industrial use increased by 7 percent, and municipal use increased by 12 percent.

From 1999 to 2001, water levels declined in 10 of 15 wells in the unconfined part of the aquifer, and the median change was -0.4 foot. Water levels declined in 8 of 16 wells in the confined part of the aquifer, and the median change was -0.2 foot.

From the prestress period (prior to 1965) to 2001, the median water-level change for 33 wells was -17.2 feet. Median water-level changes were -1.2 feet for 15 wells in the unconfined part of the aquifer and -31.0 feet for 18 wells in the confined part.

Discharges were measured once in 1999 and once in 2001 at four springs. Discharges decreased by 5 percent and 33 percent at two springs and increased by 3 percent and 81 percent at two springs. For about the past 10 years, discharges did not significantly change in Burro Spring, the unnamed spring near Dennehotso, and Moenkopi School Spring. The record of discharge from a consistent measuring point for Pasture Canyon Spring is too short for statistical analysis of trends.

Continuous records of surface-water discharge have been collected from July 1976 to 2000 at Moenkopi Wash, July 1996 to 2000 at Laguna Creek, June 1993 to 2000 at Dinnebito Wash, and April 1994 to 2000 at Polacca Wash. Median flows for November, December, January, and February of each water year were used as an index of ground-water discharge to those streams. There is no significant trend in the median winter flows for Moenkopi Wash from 1977 to 2000. The records for the other three streams are too short for a statistical analysis of trends. The median winter flows for Dinnebito Wash and Polacca Wash, however, appear to have decreased during the last 6 years. There is no apparent trend in the median winter flows for Laguna Creek since 1997.

In 2001, water samples were collected from 12 wells and 4 springs and analyzed for selected chemical constituents. Dissolved-solids concentrations ranged from 102 to 628 milligrams per liter. Water samples from 9 of the wells and from the 4 springs had less than 350 milligrams per liter of dissolved solids. Water-chemistry data with sufficient years of record for a statistical analysis of trends over time are available from 7 wells and 4 springs. From about the mid-1980s or early 1990s to 2001 there are no
\end{abstract}


significant trends in the concentrations of dissolved solids, chloride, and sulfate in water samples from 6 of the 7 wells. The concentration of one tested constituent (dissolved solids) in samples from Rocky Ridge PM3 significantly increased from 1990 to 2001 . From the late $1980 \mathrm{~s}$ to 2001, there are no significant trends in the concentrations of dissolved solids, chloride, and sulfate in water samples from Burro Spring, the unnamed spring near Dennehotso, and Pasture Canyon Spring. From 1987 to 2001, concentrations of chloride and sulfate significantly increased in water samples from Moenkopi School Spring and concentrations of dissolved solids did not significantly change.

The performance and sensitivity of the 1988 USGS numerical model of the $\mathrm{N}$ aquifer were analyzed. The overall performance of the model in steady-state conditions is reasonable for residuals of heads (difference between observed and simulated steady-state heads); 80 percent of the absolute values of residuals are less than 38 feet. Simulated flows are about 40 percent different than estimated flows at two of three discharge areas; however, this comparison is only a rough approximation of performance because the accuracy of the estimated steady-state flows is uncertain.

The overall performance of the model for transient conditions is fair for residuals of changes in head (difference between observed and simulated changes in head from steady state to 1999); 80 percent of the absolute values of residuals are less than 31 feet. The model is biased in two areas. In the Tuba City area, simulated changes in head are more negative than observed changes in head; all six residuals are positive, and three residuals are between 75 and 155 feet. In the confined area of the aquifer, observed changes in head are more negative than simulated changes in head; 12 of the 17 residuals are negative, and 8 residuals are between -57 and -20 feet.

Analysis of model sensitivity indicates that recharge, transmissivity, and storage coefficient are the most important parameters for estimating heads, changes in heads, and flows. A strong correlation between recharge and transmissivity and a lack of independent and reliable estimates of recharge, transmissivity, and discharge create a uniqueness problem in model calibration. Several models could be constructed and calibrated with different values of recharge or transmissivity and still have similar fits to the observed data. Information from recent data and studies and more advanced modeling techniques could be used to develop a more representative and less uncertain model. Future data collection and studies should focus on obtaining a better definition of recharge, discharge, transmissivity, and storage coefficient.

\section{INTRODUCTION}

The Black Mesa area includes about 5,400 $\mathrm{mi}^{2}$ in northeastern Arizona (fig. 1) and has a diverse topography that includes flat plains, mesas, and incised drainages. Black Mesa is about 2,000 $\mathrm{mi}^{2}$, is bounded by 2,000-foot cliffs on the north and northeast sides, and slopes gradually downward to the south and southwest. Availability of water is an important issue in the study area because of continued ground-water withdrawals, a growing population, and an annual precipitation that averages about 6 to 14 in.

The $\mathrm{N}$ aquifer is the major source of water for industrial and municipal uses in the Black Mesa area. The $\mathrm{N}$ aquifer consists of three formations - the Navajo Sandstone, the Kayenta Formation, and the Lukachukai Member ${ }^{1}$ of the Wingate Sandstone that are hydraulically connected and function as a single aquifer (fig. 2). Within the Black Mesa area, Peabody Western Coal Company is the principal industrial user of water, and the Navajo Nation and Hopi Tribe are the principal domestic and municipal users.

Withdrawals from the $\mathrm{N}$ aquifer in the Black Mesa area have been increasing during the last 35 years (table 1). Peabody Western Coal Company began operating a strip mine in the northern part of the mesa in 1968. The quantity of water pumped by the company increased from about 100 acre-ft in 1968 to a maximum of 4,740 acre-ft in 1982. About 4,490 acre-ft of water was pumped in 2000. Withdrawals for municipal use from the $\mathrm{N}$ aquifer have increased steadily from an estimated 250 acre-ft in 1968 to 3,250 acre-ft in 2000.

\footnotetext{
${ }^{1}$ The name Lukachukai Member was formally abandoned by Dubiel (1989) and is used herein for report continuity in the monitoring program as it relates to that part of the Wingate Sandstone included in the $\mathrm{N}$ aquifer.
} 


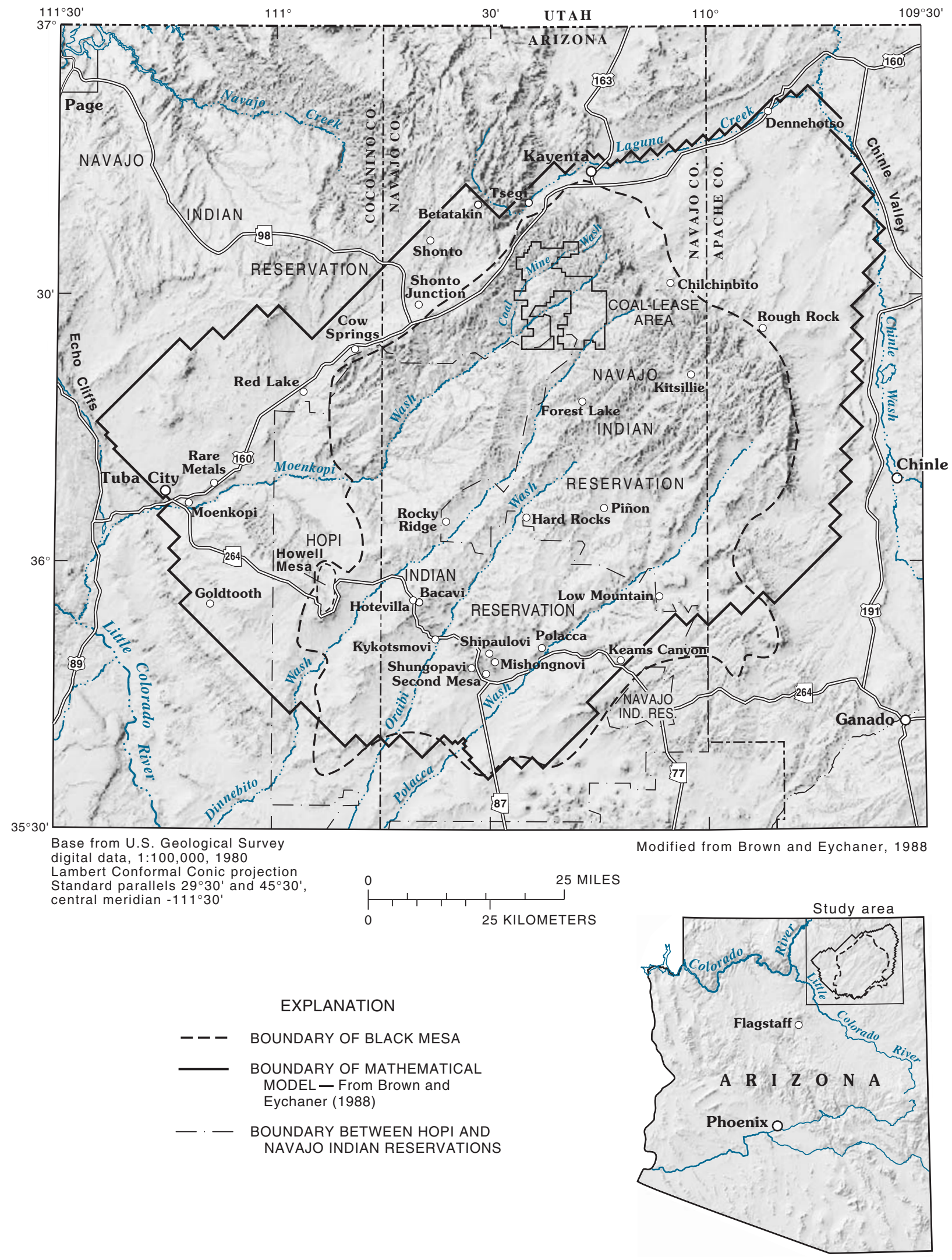

Figure 1. Location of study area. 


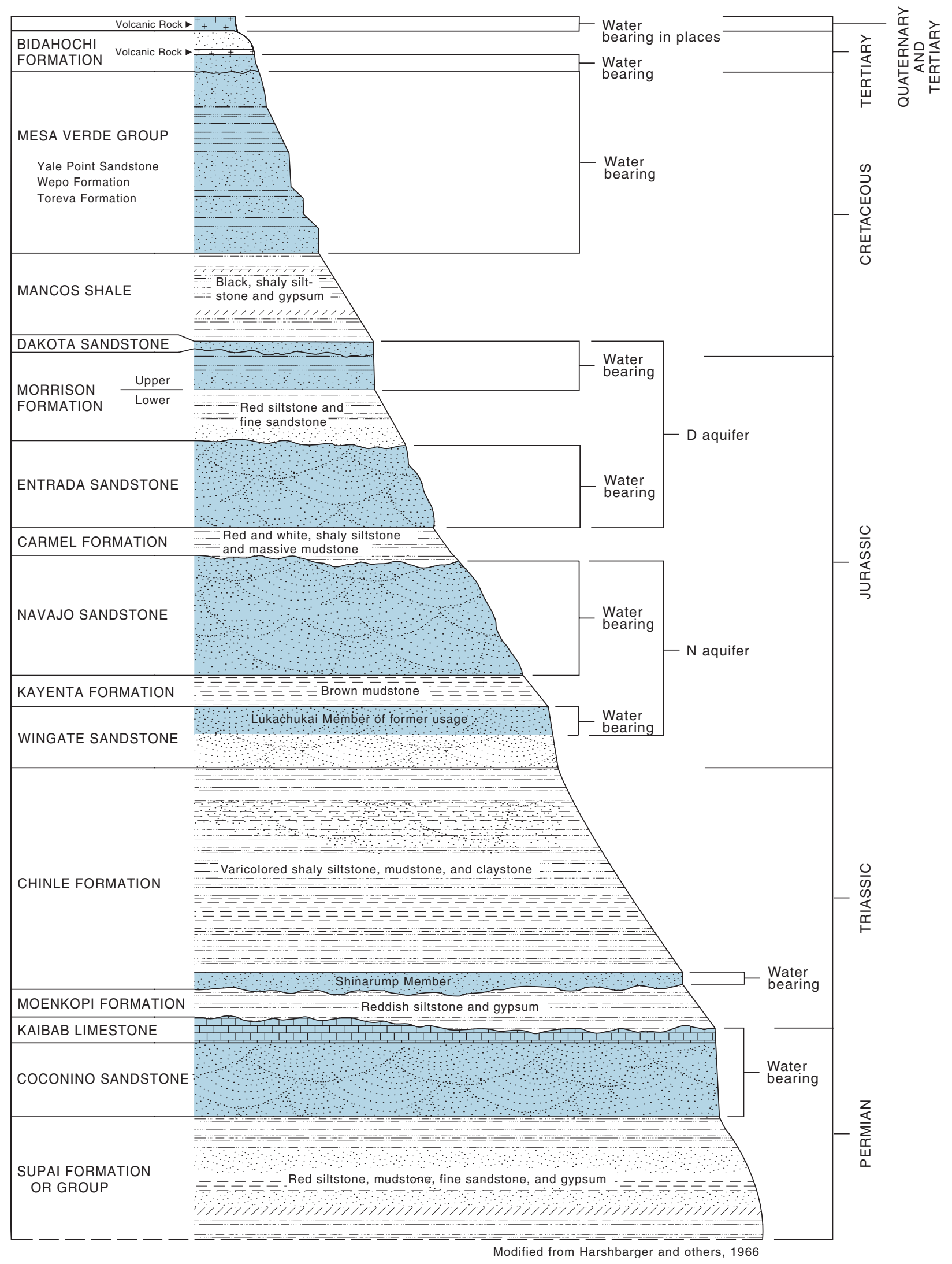

Figure 2. Rock formations and hydrogeologic units of the Black Mesa area, Arizona (not to scale). The $\mathrm{N}$ aquifer is approximately 1,000 feet thick. 
Table 1. Withdrawals from the N aquifer, Black Mesa area, Arizona, 1965-2000

[Values are rounded to nearest 10 acre-feet. Data for 1965-79 from Eychaner (1983). Total withdrawals in Littin and Monroe (1996) were for the confined part of the aquifer]

\begin{tabular}{|c|c|c|c|c|c|c|c|c|c|}
\hline \multirow[b]{2}{*}{ Year } & \multirow[b]{2}{*}{ Industrial $^{1}$} & \multicolumn{2}{|c|}{ Municipal $^{2,3}$} & \multirow{2}{*}{$\begin{array}{c}\text { Total } \\
\text { withdrawals }\end{array}$} & \multirow[b]{2}{*}{ Year } & \multirow[b]{2}{*}{ Industrial $^{1}$} & \multicolumn{2}{|c|}{ Municipal ${ }^{2,3}$} & \multirow{2}{*}{$\begin{array}{c}\text { Total } \\
\text { withdrawals }\end{array}$} \\
\hline & & Confined & Unconfined & & & & Confined & Unconfined & \\
\hline 1965 & 0 & 50 & 20 & 70 & 1983 & 4,460 & 1,360 & 1,280 & 7,100 \\
\hline 1966 & 0 & 110 & 30 & 140 & 1984 & 4,170 & 1,070 & 1,400 & 6,640 \\
\hline 1967 & 0 & 120 & 50 & 170 & 1985 & 2,520 & 1,040 & 1,160 & 4,720 \\
\hline 1968 & 100 & 150 & 100 & 350 & 1986 & 4,480 & 970 & 1,260 & 6,710 \\
\hline 1969 & 40 & 200 & 100 & 340 & 1987 & 3,830 & 1,130 & 1,280 & 6,240 \\
\hline 1970 & 740 & 280 & 150 & 1,170 & 1988 & 4,090 & 1,250 & 1,310 & 6,650 \\
\hline 1971 & 1,900 & 340 & 150 & 2,390 & 1989 & 3,450 & 1,070 & 1,400 & 5,920 \\
\hline 1972 & 3,680 & 370 & 250 & 4,300 & 1990 & 3,430 & 1,170 & 1,210 & 5,810 \\
\hline 1973 & 3,520 & 530 & 300 & 4,350 & 1991 & 4,020 & 1,140 & 1,300 & 6,460 \\
\hline 1974 & 3,830 & 580 & 360 & 4,770 & 1992 & 3,820 & 1,180 & 1,410 & 6,410 \\
\hline 1975 & 3,500 & 600 & 510 & 4,610 & 1993 & 3,700 & 1,250 & 1,570 & 6,520 \\
\hline 1976 & 4,180 & 690 & 640 & 5,510 & 1994 & 4,080 & 1,210 & 1,600 & 6,890 \\
\hline 1977 & 4,090 & 750 & 730 & 5,570 & 1995 & 4,340 & 1,220 & 1,510 & 7,070 \\
\hline 1978 & 3,000 & 830 & 930 & 4,760 & 1996 & 4,010 & 1,380 & 1,650 & 7,040 \\
\hline 1979 & 3,500 & 860 & 930 & 5,290 & 1997 & 4,130 & 1,380 & 1,580 & 7,090 \\
\hline 1980 & 3,540 & 910 & 880 & 5,330 & 1998 & 4,030 & 1,440 & 1,590 & 7,060 \\
\hline 1981 & 4,010 & 960 & 1,000 & 5,970 & 1999 & 4,210 & 1,420 & 1,480 & 7,110 \\
\hline 1982 & 4,740 & 870 & 960 & 6,570 & 2000 & 4,490 & 1,610 & 1,640 & 7,740 \\
\hline
\end{tabular}

${ }^{1}$ Metered pumpage from the confined part of the aquifer by Peabody Western Coal Company.

${ }^{2}$ Does not include withdrawals from the wells equipped with windmills.

${ }^{3}$ Includes estimated pumpage, 1965-73, and metered pumpage, 1974-79, at Tuba City; metered pumpage at Kayenta and estimated pumpage at Chilchinbito, Rough Rock, Piñon, Keams Canyon, and Kykotsmovi before 1980; metered and estimated pumpage furnished by the Navajo Tribal Utility Authority and the Bureau of Indian Affairs and collected by the U.S. Geological Survey, 1980-85; and metered pumpage furnished by the Navajo Tribal Utility Authority, the Bureau of Indian Affairs, various Hopi Village Administrations, and the U.S. Geological Survey, 1986-2000.

The Navajo Nation and the Hopi Tribe have been concerned about the long-term effects of withdrawals from the $\mathrm{N}$ aquifer on available water supplies, on stream and spring discharge, and on ground-water chemistry. In 1971, these concerns led to the establishment of a monitoring program of the water resources in Black Mesa by the U.S. Geological Survey (USGS) in cooperation with the Arizona Department of Water Resources (ADWR). In 1983, the Bureau of Indian Affairs (BIA) joined the cooperative effort. Since 1983, the Navajo Tribal Utility Authority (NTUA); Peabody Western Coal Company; the Hopi Tribe; and the Western Navajo Agency, Chinle Agency, and Hopi Agency of the BIA have assisted in the collection of hydrologic data.

\section{Purpose and Scope}

This report presents results of ground-water, surface-water, and water-chemistry monitoring in the Black Mesa area from January 2000 to June 2001, and results of analyses of the performance and sensitivity of a numerical model of the $\mathrm{N}$ aquifer developed by the USGS in 1988. The monitoring is designed to determine the effects of industrial and municipal pumpage from the $\mathrm{N}$ aquifer on ground-water levels, stream and spring discharge, and ground-water chemistry. Continuous and periodic data are collected for ground water and surface water. Ground-water data include pumpage, water levels, spring discharges, and water chemistry. Surface-water data include discharges at four continuous-record streamflow-gaging stations. The performance analysis was done to determine how well the model has simulated water-level data collected since the model was constructed. The sensitivity analysis was done to determine relations among the model parameters, observation data, and simulated values. The performance and sensitivity analyses are also a logical first step for updating and improving the model. 


\section{Previous Investigations}

Eighteen progress reports on the monitoring program for the Black Mesa area have been prepared by the USGS (U.S. Geological Survey, 1978; G.W. Hill, hydrologist, U.S. Geological Survey, written commun., 1982, 1983; Hill, 1985; Hill and Whetten, 1986; Hill and Sottilare, 1987; Hart and Sottilare, 1988, 1989; Sottilare, 1992; Littin, 1992, 1993; Littin and Monroe, 1995a, 1995b, 1996, 1997; Littin and others, 1999; Truini and others, 2000; and Thomas and Truini, 2000). Most of the data from the monitoring program are contained in these reports. Stream-discharge and periodic water-quality data from Moenkopi Wash collected before the 1986 water year were published in U.S. Geological Survey (1963-64a, b; 1965-74a, b; 1976-83), White and Garrett (1984, 1986, 1987, 1988), Boner and others $(1989,1990,1991,1992)$, Smith and others $(1993,1994,1995,1996,1997)$, and Tadayon and others (1998, 1999, 2000, 2001). Before the monitoring program, a large data-collection effort in the 1950s resulted in a compilation of well and spring data for the Navajo and Hopi Indian Reservations (Davis and others, 1963).

Many interpretive studies have been done in the Black Mesa area. Cooley and others (1969) made the first comprehensive evaluation of the regional hydrogeology of the Black Mesa area. Eychaner (1983) developed a two-dimensional numerical model of ground-water flow in the $\mathrm{N}$ aquifer. Brown and Eychaner (1988) recalibrated the model using a finer grid and revised estimates of selected aquifer characteristics. GeoTrans, Inc. (1987) also developed a two-dimensional model of the $\mathrm{N}$ aquifer in the 1980s. In the late 1990s, HSIGeoTrans, Inc. and Waterstone Environmental Hydrology and Engineering, Inc. (1999) developed a detailed three-dimensional numerical model of the $\mathrm{D}$ and $\mathrm{N}$ aquifers.

Kister and Hatchett (1963) made the first comprehensive evaluation of the chemistry of water from wells and springs in the Black Mesa area. HSIGeoTrans, Inc. (1993) evaluated the major-ion and isotopic chemistry of the $\mathrm{D}$ and $\mathrm{N}$ aquifers. Lopes and Hoffmann (1997) analyzed ground-water ages, recharge, and hydraulic conductivity of the $\mathrm{N}$ aquifer using geochemical techniques. Zhu and others (1998) estimated ground-water recharge using isotopic data and flow estimates from the model developed by GeoTrans, Inc. (1987).

\section{HYDROLOGIC DATA}

The timing of data collection was changed in 20002001 for the Black Mesa monitoring program, but the frequency and interval of data collection remains the same as in previous years. Continuous data are still compiled for January to December. These data include ground-water withdrawals from wells and daily mean discharges at four streamflow gaging stations. Data collected annually and compared from year to year are now collected in the spring (March-June). Previously, these data were collected in the fall-winter (OctoberDecember). These annual data include ground-water levels, ground-water chemistry, and spring discharges. This transition from winter to spring data collection for this report has resulted in about a 16-month interval between measurements (December 1999 to April 2001) instead of the previous 12-month interval. Annual data collection in the future will be from spring to spring (12 months).

The annual data collection was changed from winter to spring because traveling conditions in the winter in the Black Mesa area are problematic, and it was often difficult to drive to well and spring sites. Several times in the past few years, the data collection could not be completed in the planned 3-month winter period. After 2001, the interval will be 12 months between measurements, and the spring-to-spring hydrologic changes should be comparable to the previous winter-to-winter changes. During most of the 1980s, measurements of water levels and collection of water-quality samples for this monitoring program were done in the spring.

In 2000-2001, the Black Mesa monitoring program included metering and estimating ground-water withdrawals, measuring depth to ground water, measuring discharge in streams and springs, and collecting and analyzing water samples from wells and springs. Ground-water withdrawals from 33 well systems, water levels at 6 observation wells, and surface-water discharge at 4 sites were monitored continuously. Discharge at 4 springs and ground-water levels at 27 wells were measured annually. Spring discharges and ground-water levels were measured between March and June 2001. Ground-water samples were collected from 12 wells and 4 springs in MarchJune 2001 and analyzed for chemical constituents. Identification information for the 47 wells used for water-level measurements and water-quality sampling is shown in table 2. 
Table 2. Identification numbers and names of study wells, Black Mesa area, Arizona

[Dashes indicate no data]

\begin{tabular}{|c|c|c|}
\hline $\begin{array}{l}\text { U.S. Geological Survey } \\
\text { identification number }\end{array}$ & Common name or location & $\begin{array}{c}\text { Bureau of Indian Affairs } \\
\text { site number }\end{array}$ \\
\hline 354749110300101 & Second Mesa PM2 & --- \\
\hline 355023110182701 & Keams Canyon PM2 & --- \\
\hline 355215110375001 & Kykotsmovi PM2 & --- \\
\hline 355230110365801 & Kykotsmovi PM1 & --- \\
\hline 355236110364501 & Kykotsmovi PM3 & --- \\
\hline 355428111084601 & Goldtooth & $3 \mathrm{~A}-28$ \\
\hline 355518110400301 & Hotevilla PM1 & --- \\
\hline 355648110475501 & Howell Mesa & $6 \mathrm{H}-55$ \\
\hline 355924110485001 & Howell Mesa & $3 \mathrm{~K}-311$ \\
\hline 360055110304001 & BM observation well 5 & $4 \mathrm{~T}-519$ \\
\hline 360217111122601 & Tuba City & $3 K-325$ \\
\hline 360422110353501 & Rocky Ridge PM3 & --- \\
\hline 360527110122501 & Piñon NTUA 1 & --- \\
\hline 360614110130801 & Piñon PM6 & --- \\
\hline 360734111144801 & Tuba City & $3 \mathrm{~T}-333$ \\
\hline 360904111140201 & Tuba City NTUA 1 & 3T-508 \\
\hline 360918111080701 & Tuba City Rare Metals 2 & --- \\
\hline 360924111142201 & Tuba City NTUA 3 & --- \\
\hline 360953111142401 & Tuba City NTUA 4 & $3 \mathrm{~T}-546$ \\
\hline 361225110240701 & BM observation well 6 & --- \\
\hline 361737110180301 & Forest Lake NTUA 1 & $4 \mathrm{~T}-523$ \\
\hline 361832109462701 & Rough Rock & $10 \mathrm{~T}-258$ \\
\hline 361933110565001 & Red Lake PM1 & --- \\
\hline 362043110030501 & Kitsillie NTUA 2 & --- \\
\hline 362149109463301 & Rough Rock & 10R-111 \\
\hline 362333110250001 & Peabody 9 & --- \\
\hline 362406110563201 & White Mesa Arch & $1 \mathrm{~K}-214$ \\
\hline 362418109514601 & Rough Rock PM5 & --- \\
\hline 362456110503001 & Cow Springs & $1 \mathrm{~K}-225$ \\
\hline 362647110243501 & Peabody 4 & --- \\
\hline 362823109463101 & Rough Rock & 10R-119 \\
\hline 362936109564101 & BM observation well 1 & $8 \mathrm{~T}-537$ \\
\hline 363013109584901 & Sweetwater Mesa & $8 \mathrm{~K}-443$ \\
\hline 363103109445201 & Rough Rock & $9 Y-95$ \\
\hline 363137110044702 & Chilchinbito PM3 & --- \\
\hline 363143110355001 & BM observation well 4 & $2 \mathrm{~T}-514$ \\
\hline 363213110342001 & Shonto Southeast & $2 \mathrm{~K}-301$ \\
\hline 363232109465601 & Rough Rock & 9Y-92 \\
\hline 363309110420501 & Shonto & $2 \mathrm{~K}-300$ \\
\hline 363423110305501 & Shonto Southeast & $2 \mathrm{~T}-502$ \\
\hline 363727110274501 & Long House Valley & $8 \mathrm{~T}-510$ \\
\hline 363850110100801 & BM observation well 2 & $8 \mathrm{~T}-538$ \\
\hline 364034110240001 & Marsh Pass & $8 \mathrm{~T}-522$ \\
\hline 364226110171701 & Kayenta West & $8 \mathrm{~T}-541$ \\
\hline 364248109514601 & Northeast Rough Rock & $8 \mathrm{~A}-180$ \\
\hline 364338110154601 & BM observation well 3 & $8 \mathrm{~T}-500$ \\
\hline 364344110151201 & Kayenta PM2 & 8A-295 \\
\hline
\end{tabular}




\section{Withdrawals from the $\mathbf{N}$ Aquifer}

Withdrawals from the $\mathrm{N}$ aquifer are separated into three categories-(1) industrial use from the confined part of the aquifer, (2) municipal use from the confined part of the aquifer, and (3) municipal use from the unconfined part of the aquifer (table 1, fig. 3). The industrial category includes eight wells at the well field of Peabody Western Coal Company in northern Black Mesa (fig. 4). The BIA, NTUA, and Hopi Tribe operate about 70 municipal wells. Withdrawals from the $\mathrm{N}$ aquifer were compiled primarily on the basis of metered data (tables 1 and 3).

Withdrawals from wells equipped with windmills are not measured in this monitoring program. About 270 windmills in the Black Mesa area withdraw water from the $\mathrm{D}$ and $\mathrm{N}$ aquifers, and estimated total withdrawals by the windmills are about 65 acre-ft/yr (HSIGeoTrans, Inc., and Waterstone Environmental Hydrology and Engineering, Inc., 1999). This amount is less than 1 percent of the total annual withdrawal from the $\mathrm{N}$ aquifer.
In 2000, the total ground-water withdrawal from the $\mathrm{N}$ aquifer was about 7,740 acre-ft (table 1), which is a 9 percent increase from the total withdrawal in 1999. Withdrawals for municipal use from the confined part of the aquifer totaled 1,610 acre-ft, which is a 13 percent increase from 1999. Withdrawals for municipal use from the unconfined part of the aquifer totaled 1,640 acre-ft, which is an 11 percent increase. Withdrawals for industrial use totaled 4,490 acre-ft, which is a 7 percent increase.

Withdrawals from the $\mathrm{N}$ aquifer have been increasing since the 1970s (table 1, fig. 3). Total withdrawals increased from 1,170 acre-ft in 1970 to 4,300 acre-ft in 1972 when industrial use increased from 740 to 3,680 acre-ft. Since 1973, industrial use has fluctuated between 2,520 and 4,740 acre-ft/yr. Municipal use increased by about 20 percent per year during the 1970s, slowed to an increase of about 4 percent per year in the 1980 s, and slowed further to an increase of about 3 percent per year in the 1990s.

In the 1970s, industrial use was about 75 percent of the total withdrawal. With the increase in municipal use over the last 30 years, industrial use, as a percentage of total withdrawals, has declined to about 60 percent in the late 1990s and in 2000.

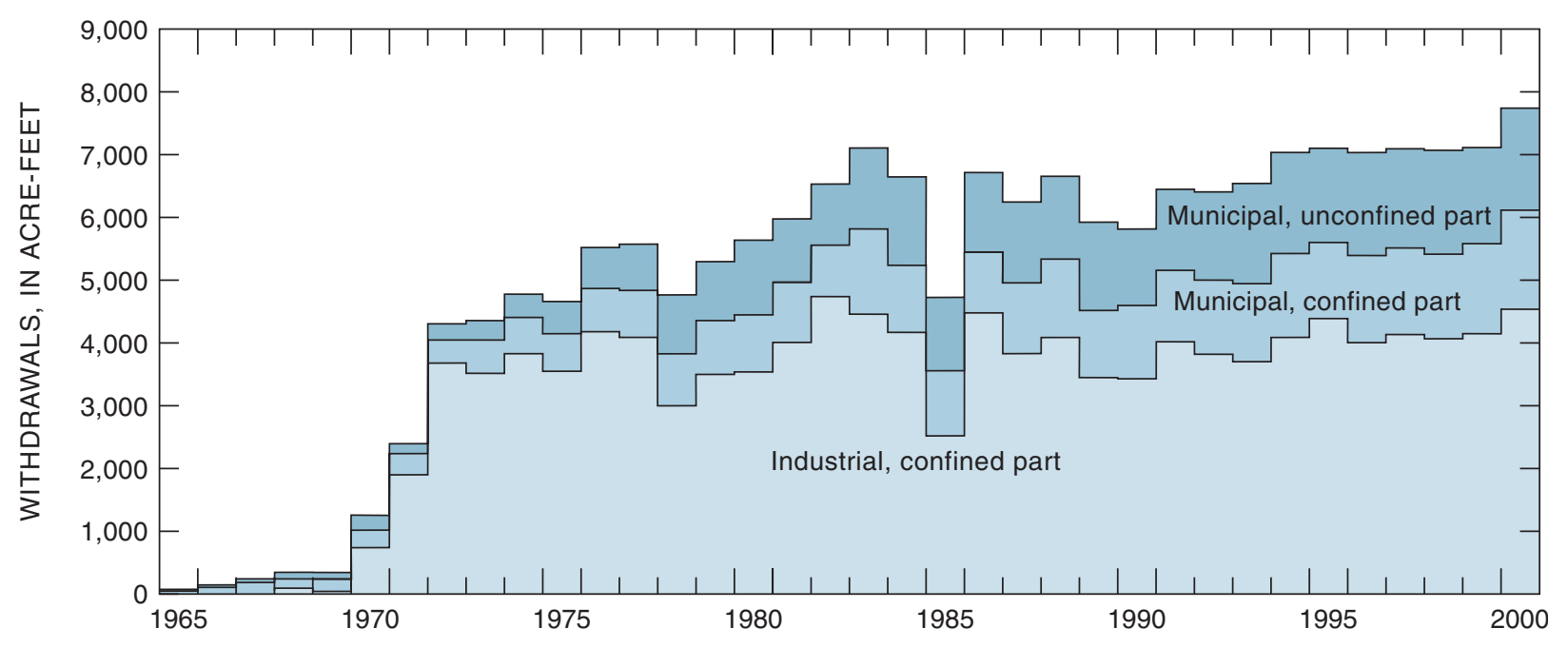

Figure 3. Withdrawals from the N aquifer, Black Mesa area, Arizona, 1965-2000. 


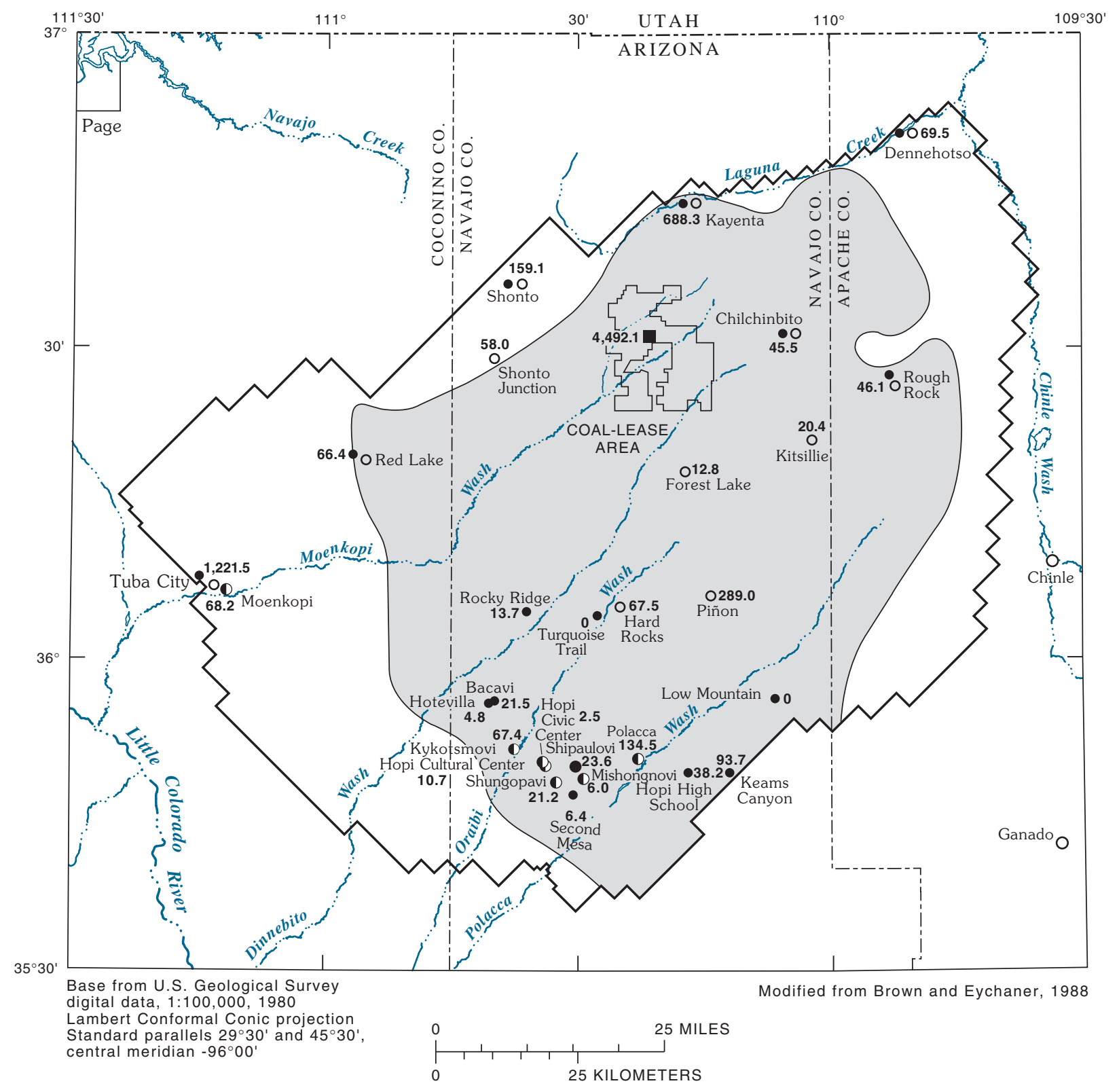

EXPLANATION

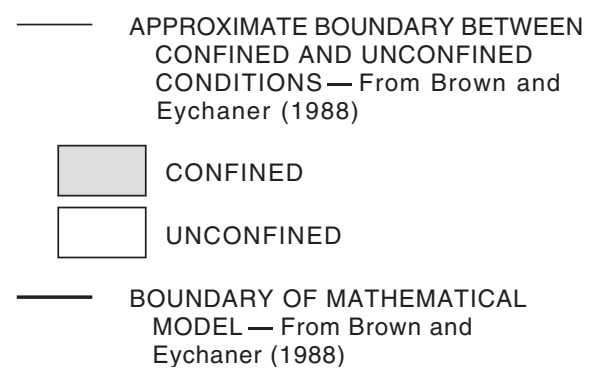

\begin{tabular}{|c|c|c|}
\hline WELL-SYSTEM OWNER & Hotevilla $_{4.8}^{\bullet}$ & WITHDRAWALS FROM THE N \\
\hline Bureau of Indian Affairs & & system name; $\mathbf{4 . 8}$, is the total \\
\hline Navajo Tribal Utility Authority & & $\begin{array}{l}\text { withdrawal in acre-feet for } 2000 \text {. } \\
\text { The total is cumulative at locations }\end{array}$ \\
\hline Hopi Tribe & & served by multiple wells \\
\hline
\end{tabular}
BOUNDARY OF MATHEMATICAL
MODEL - From Brown and
Eychaner (1988)

Figure 4. Locations of well systems monitored for withdrawals from the $\mathrm{N}$ aquifer, Black Mesa area, Arizona, 2000. 
Table 3. Withdrawals from the $N$ aquifer by well system, Black Mesa area, Arizona, 2000

[Withdrawals, in acre-feet, are from flowmeter measurements. BIA, Bureau of Indian Affairs; NTUA, Navajo Tribal Utility Authority; USGS, U.S. Geological Survey; Peabody, Peabody Western Coal Company; Hopi, Hopi Village Administrations; BIA Roads, Bureau of Indian Affairs, Division of Roads]

\begin{tabular}{|c|c|c|c|c|}
\hline \multirow{2}{*}{$\begin{array}{c}\text { Well system } \\
\text { (one or more wells) }\end{array}$} & \multirow[b]{2}{*}{ Owner } & \multirow[b]{2}{*}{ Source of data } & \multicolumn{2}{|c|}{ Withdrawals } \\
\hline & & & Confined aquifer & Unconfined aquifer \\
\hline Chilchinbito & BIA & USGS/BIA & 7.8 & \\
\hline Dennehotso & BIA & USGS/BIA & & 35.1 \\
\hline Hopi High School & BIA & USGS/BIA & 38.2 & \\
\hline Hotevilla & BIA & USGS/BIA & 4.8 & \\
\hline Kayenta & BIA & USGS/BIA & 76.3 & \\
\hline Keams Canyon & BIA & USGS/BIA & 93.7 & \\
\hline Low Mountain & BIA & USGS/BIA & ${ }^{1} 0$ & \\
\hline Piñon & BIA & USGS/BIA & ${ }^{1} 0$ & \\
\hline Red Lake & BIA & USGS/BIA & & 8.0 \\
\hline Rocky Ridge & BIA & USGS/BIA & 13.7 & \\
\hline Rough Rock & BIA & USGS/BIA & 32.9 & \\
\hline Second Mesa & BIA & USGS/BIA & 6.4 & \\
\hline Shonto & BIA & USGS/BIA & & 142.4 \\
\hline Tuba City & BIA & USGS/BIA & & 164.3 \\
\hline Turquoise Trail & BIA & BIA Roads & ${ }^{1} 0$ & \\
\hline Chilchinbito & NTUA & NTUA & 37.7 & \\
\hline Dennehotso & NTUA & NTUA & & 34.4 \\
\hline Forest Lake & NTUA & NTUA & 12.8 & \\
\hline Hard Rock & NTUA & NTUA & 67.5 & \\
\hline Kayenta & NTUA & NTUA & 612.0 & \\
\hline Kitsillie & NTUA & NTUA & 20.4 & \\
\hline Piñon & NTUA & NTUA & 289.0 & \\
\hline Red Lake & NTUA & NTUA & & 58.4 \\
\hline Rough Rock & NTUA & NTUA & 13.2 & \\
\hline Shonto & NTUA & NTUA & & 16.7 \\
\hline Shonto Junction & NTUA & NTUA & & 58.0 \\
\hline Tuba City & NTUA & NTUA & & $1,057.2$ \\
\hline Mine Well Field & Peabody & Peabody & $24,492.1$ & \\
\hline Bacavi & Hopi & USGS/Hopi & 21.5 & \\
\hline Hopi Civic Center & Hopi & USGS/Hopi & 2.5 & \\
\hline Hopi Cultural Center & Hopi & USGS/Hopi & 10.7 & \\
\hline Kykotsmovi & Hopi & USGS/Hopi & 67.4 & \\
\hline Mishongnovi & Hopi & USGS/Hopi & 6.0 & \\
\hline Moenkopi & Hopi & USGS/Hopi & & 68.2 \\
\hline Polacca & Hopi & USGS/Hopi & ${ }^{3} 134.5$ & \\
\hline Shipaulovi & Hopi & USGS/Hopi & 23.6 & \\
\hline Shungopovi & Hopi & USGS/Hopi & 21.2 & \\
\hline
\end{tabular}


In an effort to improve and ensure the accuracy of ground-water withdrawal data, a quality-assurance program was begun in 1985 for withdrawal data from industrial and municipal wells completed in the $\mathrm{N}$ aquifer. Nearly all industrial and municipal wells in the study area are equipped with totalizing flowmeters to measure ground-water withdrawals. The flowmeters on the wells are tested about once every 5 years by measuring pumpage with a calibrated mechanical flowmeter and comparing the measured pumpage to the metered pumpage. For the purpose of this study, the allowable difference between the discharge measured by the permanent totalizing flowmeter and the test meter is 10 percent. No testing of flowmeters was done this past year.

\section{Ground-Water Levels in the $\mathbf{N}$ Aquifer}

Ground water in the $\mathrm{N}$ aquifer is under confined conditions in the central part of the study area and under unconfined or water-table conditions around the periphery (fig. 5). The ground water generally flows radially outward from recharge areas near Shonto to the southwest, south, southeast, and east (Lopes and Hoffman, 1997).

Ground-water levels are measured each year and compared with levels from previous years to determine changes over time. In 2001, water levels were measured in 33 wells that are used for observation, municipal supply, or stock supply (table 4). Six of the 33 wells are observation wells that were operated on a continuous basis; water levels were recorded daily. Water levels were measured manually twice a year in the six continuous-observation wells.

The wells used for water-level measurements are spread throughout the study area (fig. 5). Although all the wells are completed in the $\mathrm{N}$ aquifer, characteristics of the wells vary considerably. Construction dates range from 1934 to 1993, depths range from 107 to $3,535 \mathrm{ft}$, and depths to the top of the $\mathrm{N}$ aquifer range from 0 to 2,400 ft (table 5).

From winter 1999 to spring 2001 (about 16 months), water levels declined in 18 of 31 wells. Two wells measured in 2001 (3K-311 and Kykotsmovi PM3) are not used in the annual comparison because the previous measurement was made more than 4 years ago. The median water-level change in the 31 wells was $-0.4 \mathrm{ft}$. Changes ranged from $-10.8 \mathrm{ft}$ in the Piñon PM6 well to $+6.0 \mathrm{ft}$ in the Keams Canyon PM2 well (table 4).
From winter 1999 to spring 2001, water levels declined in 10 of 15 wells in unconfined areas. The median change was $-0.4 \mathrm{ft}$, and the changes ranged from $-7.6 \mathrm{ft}$ to $+2.3 \mathrm{ft}$. In confined areas, water levels declined in 8 of 16 wells. The median change was $-0.2 \mathrm{ft}$, and the changes ranged from $-10.8 \mathrm{ft}$ to $+6.0 \mathrm{ft}$ (table 4).

Median annual water-level changes for observations wells from 1983 to 2001 are shown in figure 6. Median annual changes before 1983 are not shown because there were insufficient water-level data to compute median values. Trends in the annual waterlevel changes from 1983 to 2001 were tested with a two-sided nonparametric Kendall's tau statistical test (Conover, 1980). There is a significant decreasing trend in the median annual water-level changes for wells in unconfined areas ( $p$-value $=0.035)$, and the average annual median change was $0.2 \mathrm{ft}$. There is no significant trend in the water-level changes for wells in confined areas ( $p$-value $=0.139)$, and the average annual median change was $-1.8 \mathrm{ft}$.

From the prestress period (prior to 1965) to 2001, the median water-level change in 33 wells was $-17.2 \mathrm{ft}$. Water levels in 15 unconfined wells had a median change of $-1.2 \mathrm{ft}$ and ranged from $-39 \mathrm{ft}$ to $+6.3 \mathrm{ft}$ (table 4). Water levels in 18 confined wells had a median change of $-31.0 \mathrm{ft}$ and ranged from $-168.8 \mathrm{ft}$ to $+9.4 \mathrm{ft}$.

Hydrographs of water levels in wells in the annual observation-well network show the time trends of changes since about 1970 or 1980 (fig. 7). Water levels in wells in unconfined areas have changed only slightly. In contrast, water levels in wells in confined areas are more variable. In some wells, there were large declines (wells Piñon PM6 and Keams Canyon PM2), and in other wells there were small changes (wells 8T522 and 10R-119).

Hydrographs for the continuously recorded Black Mesa observation wells show water-level changes since about 1972 (fig. 8). Water levels in the two wells in unconfined areas (BM1 and BM4) have had small seasonal or year-to-year variation and have had small long-term changes since 1972. Water levels in the four wells in confined areas also have had little seasonal variation (except BM3); however, the water levels have consistently declined in all the confined wells since 1972 . 


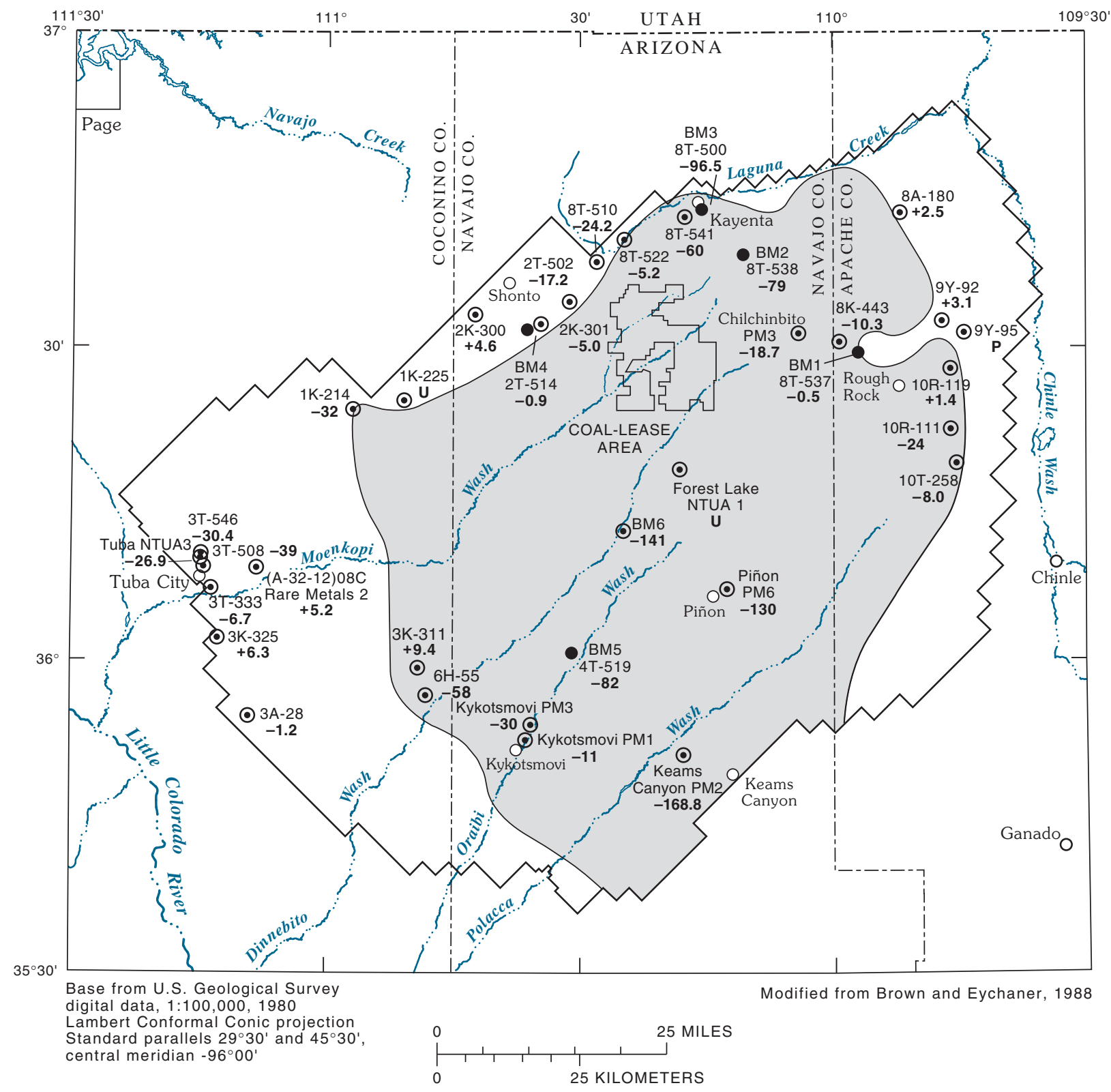

EXPLANATION

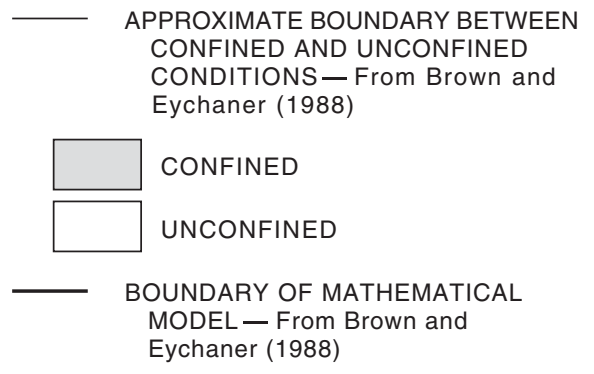

$\begin{array}{cc}\odot & \text { WELL IN WHICH DEPTH TO } \\ 6 \mathrm{H}-55 & \text { WATER WAS MEASURED } \\ \mathbf{- 5 8} & \text { ANNUALLY - First entry, } \\ & 6 \mathrm{H}-55, \text { is Bureau of Indian } \\ & \text { Affairs site number; second } \\ & \text { entry, } \mathbf{- 5 8} \text {, is change in } \\ & \text { water level, in feet, between } \\ & \text { measurement made during } \\ & \text { the prestress period and } \\ & \text { measurement made during } \\ & \text { 2001. U, unable to measure. } \\ & \text { P, well was being pumped } \\ & \text { during site visit }\end{array}$

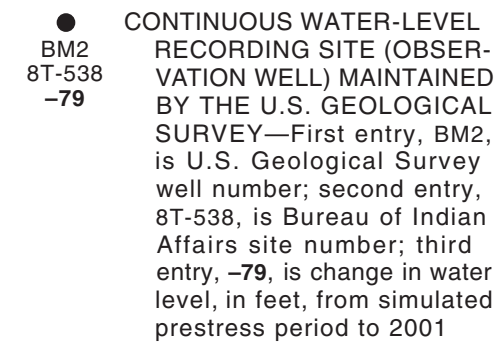

Figure 5. Water-level changes in N-aquifer wells from the prestress period (prior to 1965) to 2001, Black Mesa area, Arizona. 
Table 4. Water-level changes in wells completed in the $\mathrm{N}$ aquifer, Black Mesa area, Arizona, prestress period to 2001

[Dashes indicate no data. Do., ditto; R, reported from driller's log]

\begin{tabular}{|c|c|c|c|c|c|c|c|}
\hline \multirow[b]{2}{*}{ Common name or location } & \multirow[b]{2}{*}{$\begin{array}{c}\text { Bureau of Indian } \\
\text { Affairs site } \\
\text { number }\end{array}$} & \multicolumn{2}{|c|}{$\begin{array}{l}\text { Change in water level from } \\
\text { preceding year, in feet }\end{array}$} & \multirow{2}{*}{$\begin{array}{l}\text { Water level, } \\
\text { in feet } \\
\text { below land } \\
\text { surface, } \\
2001\end{array}$} & \multicolumn{2}{|c|}{$\begin{array}{l}\text { Prestress period } \\
\text { water level }\end{array}$} & \multirow{2}{*}{$\begin{array}{c}\text { Change in } \\
\text { water level } \\
\text { from } \\
\text { prestress } \\
\text { period to } \\
2001, \\
\text { in feet }\end{array}$} \\
\hline & & 1999-2000 & 2001 & & $\begin{array}{c}\text { Feet below } \\
\text { land } \\
\text { surface }\end{array}$ & Date & \\
\hline \multicolumn{8}{|c|}{ Unconfined area } \\
\hline BM observation well $1^{3}$ & $8 \mathrm{~T}-537$ & 0.0 & -0.3 & 374.5 & 374 & $\left({ }^{3}\right)$ & -0.5 \\
\hline BM observation well $4^{3}$ & $2 \mathrm{~T}-514$ & -1.0 & +.4 & 216.9 & ${ }^{4} 216$ & $(3)$ & -.9 \\
\hline Cow Springs & $1 \mathrm{~K}-225$ & .0 & $(5)$ & $(5)$ & 60 & $07-04-54$ & $(5)$ \\
\hline Goldtooth & $3 \mathrm{~A}-28$ & $\left(5^{5}\right)$ & $6-.5$ & 231.2 & 230.0 & $10-29-53$ & -1.2 \\
\hline Long House Valley & $8 \mathrm{~T}-510$ & -.9 & -.7 & 123.6 & 99.4 & $08-22-67$ & -24.2 \\
\hline Northeast Rough Rock & $8 \mathrm{~A}-180$ & -.7 & -.5 & 44.4 & 46.9 & $11-13-53$ & +2.5 \\
\hline Rough Rock & $9 Y-95$ & +.3 & $\left({ }^{7}\right)$ & $\left({ }^{7}\right)$ & 119.5 & $08-03-49$ & $\left({ }^{7}\right)$ \\
\hline Do & $9 Y-92$ & -.5 & -.4 & 165.7 & 168.8 & $12-13-52$ & +3.1 \\
\hline Shonto & $2 \mathrm{~K}-300$ & -.8 & +.4 & 171.9 & 176.5 & $06-13-50$ & +4.6 \\
\hline Shonto Southeast & $2 \mathrm{~K}-301$ & -.4 & -.3 & 288.9 & 283.9 & $12-10-52$ & -5.0 \\
\hline Do & $2 \mathrm{~T}-502$ & -.9 & -7.6 & 423.0 & 405.8 & $08-22-67$ & -17.2 \\
\hline Tuba City & $3 \mathrm{~T}-333$ & -1.2 & +2.3 & 29.7 & 23.0 & $12-02-55$ & -6.7 \\
\hline Do & $3 \mathrm{~K}-325$ & -.5 & +.3 & 201.7 & 208 & $06-30-55$ & +6.3 \\
\hline Tuba City Rare Metals 2 & --- & .0 & +.8 & 51.8 & 57 & $09-24-55$ & +5.2 \\
\hline Tuba NTUA 1 & $3 \mathrm{~T}-508$ & -4.9 & -.6 & 67.8 & 29 & $02-12-69$ & -39 \\
\hline Tuba NTUA 3 & --- & $6-3.6$ & -1.0 & 61.1 & 34.2 & $11-08-71$ & -26.9 \\
\hline Tuba NTUA 4 & $3 \mathrm{~T}-546$ & -.8 & -3.4 & 64.1 & 33.7 & $08-06-71$ & -30.4 \\
\hline \multicolumn{8}{|c|}{ Confined area } \\
\hline BM observation well $2^{3}$ & $8 \mathrm{~T}-538$ & -1.3 & -2.9 & 204.4 & 125 & $\left({ }^{3}\right)$ & -79 \\
\hline BM observation well $3^{3}$ & $8 \mathrm{~T}-500$ & +8.9 & -7.0 & 151.5 & ${ }^{4} 55.0$ & $04-29-63$ & -96.5 \\
\hline BM observation well $5^{3}$ & $4 \mathrm{~T}-519$ & -3.3 & -1.9 & 406.0 & 324 & $\left({ }^{3}\right)$ & -82 \\
\hline BM observation well $6^{3}$ & --- & $8-4.3$ & $8-4.4$ & 838.0 & ${ }^{4} 697$ & $\left({ }^{3}\right)$ & -141 \\
\hline Chilchinbito PM3 & --- & $6+.8$ & -.5 & 424.0 & 405.3 & $09-25-65$ & -18.7 \\
\hline Forest Lake NTUA 1 & $4 \mathrm{~T}-523$ & -4.8 & $(5)$ & $(5)$ & $1,096 \mathrm{R}$ & $05-21-82$ & $(5)$ \\
\hline Howell Mesa & $3 \mathrm{~K}-311$ & $\left({ }^{5}\right)$ & $\left({ }^{9}\right)$ & 453.6 & 463.0 & $11-03-53$ & +9.4 \\
\hline Howell Mesa & $6 \mathrm{H}-55$ & $6-1.0$ & +.2 & 270.0 & 212 & $07-08-54$ & -58 \\
\hline Kayenta West & $8 \mathrm{~T}-541$ & -1.6 & -4.1 & 290.5 & 230 & $03-17-76$ & -60 \\
\hline Keams Canyon PM2 & --- & -4.5 & +6.0 & 461.3 & 292.5 & $06-10-70$ & -168.8 \\
\hline Kykotsmovi PM1 & --- & -18.7 & +2.3 & 230.6 & 220 & $05-20-67$ & -11 \\
\hline Kykotsmovi PM3 & --- & $\left({ }^{5}\right)$ & $\left({ }^{9}\right)$ & 240.1 & 210 & $08-28-68$ & -30 \\
\hline Marsh Pass & $8 \mathrm{~T}-522$ & -.6 & -1.7 & 130.7 & 125.5 & $02-07-72$ & -5.2 \\
\hline Piñon PM6 & --- & $(5)$ & -10.8 & 873.6 & 743.6 & $05-28-70$ & -130.0 \\
\hline Rough Rock & 10R-119 & -0.8 & +0.8 & 255.2 & 256.6 & $12-02-53$ & +1.4 \\
\hline Do & $10 \mathrm{~T}-258$ & -.5 & +.3 & 309.0 & 301.0 & $04-14-60$ & -8.0 \\
\hline Do & 10R-111 & -4.0 & +1.3 & 193.7 & 170 & $08-04-54$ & -24 \\
\hline Sweetwater Mesa & $8 K-443$ & -.4 & +.3 & 539.7 & 529.4 & $09-26-67$ & -10.3 \\
\hline White Mesa Arch & $1 \mathrm{~K}-214$ & -.3 & +.6 & 220.0 & 188 & $06-04-53$ & -32 \\
\hline $\begin{array}{l}{ }^{1} \text { The dates of water-level measure } \\
\text { report (2000-2001). This interval bet } \\
\text { in the spring. } \\
{ }^{2} \text { Prestress refers to the period of } \mathrm{r} \\
\text { measurement before } 1965 \text {, the earlie } \\
{ }^{3} \text { Continuous recorder. Except for } \\
{ }^{4} \text { Prestress water levels for indicat } \\
\text { BM3 was } 77.1 \text { feet in } 1998 \text { report an } \\
{ }^{5} \text { Water level not measured becaus } \\
{ }^{6} \text { Change in water level from last } \\
{ }^{7} \text { 2001 water level influenced by p } \\
{ }^{8} \text { Water level of } 836.7 \text { feet reporte } \\
{ }^{9} \text { Change in }\end{array}$ & $\begin{array}{l}\text { ents were changed from } \\
\text { een measurements was ar } \\
\text { ord before appreciable g1 } \\
\text { water-level measurement } \\
\text { ll BM3, prestress water } \\
\text { wells were changed fron } \\
0 \text { feet in } 1995-97 \text { repor } \\
\text { f obstruction in well, no } \\
\text { asurement } 2 \text { to } 4 \text { years e } \\
\text { aping. } \\
\text { n } 1999 \text { monitoring repor } \\
\text { cause last measurement }\end{array}$ & $\begin{array}{l}\text { ill-winter (Octob } \\
\text { roximately } 16 \mathrm{~m} \\
\text { pund-water withd } \\
\text { s shown. } \\
\text { evels were estima } \\
\text { previous Black } \\
\text { The water level } \\
\text { access to well, or } \\
\text { lier. }\end{array}$ & $\begin{array}{l}\text { 9-February } 20 \\
\text { instead of the } ~ \\
\text { for mining or } \\
\text { om a ground-w } \\
\text { nonitoring rep } \\
217 \text { feet in BI } \\
\text { isited. }\end{array}$ & $\begin{array}{l}\text { D0) in the last mon } \\
\text { sual } 12 \text { months. St } \\
\text { municipal purpose } \\
\text { ater model (Brown } \\
\text { rts to more accura } \\
44 \text { and } 735.6 \text { feet i }\end{array}$ & $\begin{array}{l}\text { toring report (19) } \\
\text { bsequent annual } \\
\text { - about } 1965 . \mathrm{F} \\
\text { and Eychaner, } 19 \\
\text { ely represent pre } \\
\text { n BM6 in 1995-9 }\end{array}$ & $\begin{array}{l}\text { to spring (Marc } \\
\text { ter-level measur } \\
\text { wells that had n } \\
\text { 3). } \\
\text { ess conditions. T } \\
\text { reports. }\end{array}$ & $\begin{array}{l}\text { May 2001) in this } \\
\text { ents will be made } \\
\text { vater-level } \\
\text { water level in }\end{array}$ \\
\hline
\end{tabular}


Table 5. Well-construction characteristics, top of N aquifer, and type of data collected for wells in monitoring program, Black Mesa area, Arizona, 2000-2001

\begin{tabular}{|c|c|c|c|c|c|c|}
\hline $\begin{array}{l}\text { Bureau of Indian Affairs site } \\
\text { number, or common name }\end{array}$ & $\begin{array}{l}\text { Date well was } \\
\text { completed }\end{array}$ & $\begin{array}{l}\text { Land- surface } \\
\text { altitude, } \\
\text { in feet }\end{array}$ & $\begin{array}{l}\text { Well depth, } \\
\text { in feet } \\
\text { below land } \\
\text { surface }\end{array}$ & $\begin{array}{l}\text { Screened/open } \\
\text { interval(s), in feet } \\
\text { below land } \\
\text { surface }\end{array}$ & $\begin{array}{l}\text { Depth to top of } \\
\mathrm{N} \text { aquifer, in feet } \\
\text { below land } \\
\text { surface }\end{array}$ & $\begin{array}{l}\text { Type of data } \\
\text { collected }\end{array}$ \\
\hline 8T-537 (BM observation well 1) & $02-01-72$ & 5,864 & 850 & $\begin{array}{c}300-360 ; 400-420 \\
500-520 ; 600-620 \\
730-780\end{array}$ & 290 & Water level \\
\hline 8T-538 (BM observation well 2) & $01-29-72$ & 5,656 & 1,338 & $470-1,338$ & 452 & Water level \\
\hline 8T-500 (BM observation well 3) & $07-29-59$ & 5,724 & 868 & $712-868$ & 155 & Water level \\
\hline 2T-514 (BM observation well 4) & $02-15-72$ & 6,320 & 400 & $250-400$ & 160 & Water level \\
\hline 4T-519 (BM observation well 5) & $02-25-72$ & 5,869 & 1,683 & $1,521-1,683$ & 1,520 & Water level \\
\hline BM observation well 6 & $01-31-77$ & 6,332 & 2,507 & $1,954-2,506$ & 1,950 & Water level \\
\hline $1 \mathrm{~K}-214$ & $05-26-50$ & 5,771 & 356 & $168-356$ & 250 & Water level \\
\hline $1 \mathrm{~K}-225$ & $07-04-54$ & 5,722 & 251 & $19-251$ & ${ }^{2} 10$ & Water level \\
\hline $2 \mathrm{~K}-300$ & ${ }^{3} 06-00-50$ & 6,264 & 300 & $260-300$ & 0 & Water level \\
\hline $2 \mathrm{~K}-301$ & $06-12-50$ & 6,435 & 500 & $\begin{array}{l}318-328 \\
378-500\end{array}$ & 230 & Water level \\
\hline $2 \mathrm{~T}-502$ & $08-10-59$ & 6,670 & 523 & $12-523$ & 25 & Water level \\
\hline $3 \mathrm{~A}-28$ & 04-19-35 & 5,381 & 358 & $\left({ }^{4}\right)$ & 60 & Water level \\
\hline $3 \mathrm{~K}-311$ & ${ }^{3} 11-00-34$ & 5,855 & 745 & $\begin{array}{l}380-395 \\
605-745\end{array}$ & 615 & Water level \\
\hline $3 \mathrm{~K}-325$ & $06-01-55$ & 5,250 & 450 & $75-450$ & ${ }^{2} 30$ & Water level \\
\hline $3 \mathrm{~T}-333$ & $12-02-55$ & 4,940 & 229 & $63-229$ & 24 & Water level \\
\hline 3T-508 (Tuba City NTUA 1) & $08-25-59$ & 5,119 & 475 & $\left({ }^{4}\right)$ & 0 & $\begin{array}{l}\text { Water level, } \\
\text { withdrawals }\end{array}$ \\
\hline 3T-546 (Tuba City NTUA 4) & ${ }^{3} 08-00-71$ & 5,206 & 612 & $256-556$ & 0 & $\begin{array}{l}\text { Water level, } \\
\text { withdrawals }\end{array}$ \\
\hline 4T-523 & $10-01-80$ & 6,654 & 2,674 & $\begin{array}{l}1,870-1,910 \\
2,070-2,210 \\
2,250-2,674\end{array}$ & $\left({ }^{5}\right)$ & $\begin{array}{l}\text { Water level, } \\
\text { water chemistry, } \\
\text { withdrawals }\end{array}$ \\
\hline $6 \mathrm{H}-55$ & $12-08-44$ & 5,635 & 361 & $310-335$ & 310 & Water level \\
\hline $8 \mathrm{~A}-180$ & $01-20-39$ & 5,200 & 107 & $60-107$ & 240 & Water level \\
\hline $8 A-295$ & ${ }^{3} 00-00-36$ & 5,623 & 840 & $\begin{array}{l}268-280 \\
691-788\end{array}$ & 95 & $\begin{array}{l}\text { Water chemistry, } \\
\text { withdrawals }\end{array}$ \\
\hline $8 \mathrm{~K}-443$ & $08-15-57$ & 6,024 & 720 & $619-720$ & 590 & Water level \\
\hline $8 \mathrm{~T}-510$ & $02-11-63$ & 6,262 & 314 & $130-314$ & ${ }^{2} 125$ & Water level \\
\hline $8 \mathrm{~T}-522$ & ${ }^{3} 07-00-63$ & 6,040 & 933 & $180-933$ & 480 & Water level \\
\hline $8 \mathrm{~T}-541$ & $03-17-76$ & 5,885 & 890 & $740-890$ & 700 & Water level \\
\hline 9Y-92 & $01-02-39$ & 5,615 & 300 & $154-300$ & 250 & Water level \\
\hline 9Y-95 & $11-05-37$ & 5,633 & 300 & $145-300$ & ${ }^{2} 68$ & Water level \\
\hline 10R-111 & $04-11-35$ & 5,757 & 360 & $267-360$ & 210 & Water level \\
\hline 10R-119 & $01-09-35$ & 5,775 & 360 & (4) & 310 & Water level \\
\hline $10 \mathrm{~T}-258$ & $04-12-60$ & 5,903 & 670 & 465-670 & 460 & Water level \\
\hline Chilchinbito PM3 & $09-25-65$ & 5,950 & 1,600 & $1,140-1,570$ & 1,136 & $\begin{array}{l}\text { Water level, } \\
\text { withdrawals }\end{array}$ \\
\hline Hotevilla PM1 & $06-00-57$ & 6,357 & 1,757 & $1,500-1,750$ & 1,450 & $\begin{array}{l}\text { Water chemistry } \\
\text { withdrawals }\end{array}$ \\
\hline Keams Canyon PM2 & ${ }^{3} 05-00-70$ & 5,809 & 1,106 & $906-1,106$ & 900 & $\begin{array}{l}\text { Water level, } \\
\text { withdrawals }\end{array}$ \\
\hline Kitsillie NTUA 2 & $11-09-93$ & 6,780 & 2,620 & $\begin{array}{l}2,217-2,223 \\
2,240-2,256 \\
2,314-2,324 \\
2,344-2,394 \\
2,472-2,527\end{array}$ & 2,205 & $\begin{array}{l}\text { Water chemistry, } \\
\text { withdrawals }\end{array}$ \\
\hline
\end{tabular}


Table 5. Well-construction characteristics, top of $\mathrm{N}$ aquifer, and type of data collected for wells in monitoring program, Black Mesa area, Arizona, 2000-2001-Continued

\begin{tabular}{|c|c|c|c|c|c|c|}
\hline $\begin{array}{l}\text { Bureau of Indian Affairs site } \\
\text { number, or common name }\end{array}$ & $\begin{array}{l}\text { Date well was } \\
\text { completed }\end{array}$ & $\begin{array}{l}\text { Land- surface } \\
\text { altitude, } \\
\text { in feet }\end{array}$ & $\begin{array}{l}\text { Well depth, } \\
\text { in feet } \\
\text { below land } \\
\text { surface }\end{array}$ & $\begin{array}{l}\text { Screened/open } \\
\text { interval(s), in feet } \\
\text { below land } \\
\text { surface }\end{array}$ & $\begin{array}{l}\text { Depth to top of } \\
\mathrm{N} \text { aquifer, in feet } \\
\text { below land } \\
\text { surface }^{1}\end{array}$ & $\begin{array}{l}\text { Type of data } \\
\text { collected }\end{array}$ \\
\hline Kykotsmovi PM1 & $02-20-67$ & 5,657 & 995 & $\begin{array}{l}655-675 \\
890-990\end{array}$ & 880 & $\begin{array}{l}\text { Water level, } \\
\text { withdrawals }\end{array}$ \\
\hline Kykotsmovi PM2 & $10-14-77$ & 5,717 & 1,160 & $950-1,160$ & 890 & $\begin{array}{l}\text { Water chemistry, } \\
\text { withdrawals }\end{array}$ \\
\hline Kykotsmovi PM3 & $08-07-68$ & 5,618 & 1,220 & $850-1,220$ & 840 & $\begin{array}{l}\text { Water level, } \\
\text { withdrawals }\end{array}$ \\
\hline Peabody 4 & ${ }^{3} 05-00-68$ & 6,229 & 3,535 & $2,029-3,458$ & 2,280 & $\begin{array}{l}\text { Water chemistry, } \\
\text { withdrawals }\end{array}$ \\
\hline Peabody 9 & ${ }^{3} 00-00-83$ & 6,385 & 3,510 & $2,332-3,505$ & 2,400 & $\begin{array}{l}\text { Water chemistry, } \\
\text { withdrawals }\end{array}$ \\
\hline Piñon NTUA 1 & $02-25-80$ & 6,336 & 2,350 & $1,860-2,350$ & 1,850 & $\begin{array}{l}\text { Water chemistry } \\
\text { withdrawals }\end{array}$ \\
\hline Piñon PM6 & ${ }^{3} 02-00-70$ & 6,397 & 2,248 & $1,895-2,243$ & 1,870 & $\begin{array}{l}\text { Water level, } \\
\text { withdrawals }\end{array}$ \\
\hline Red Lake PM1 & ${ }^{3} 09-00-57$ & 5,616 & 550 & $150-510$ & 120 & $\begin{array}{l}\text { Water chemistry, } \\
\text { withdrawals }\end{array}$ \\
\hline Rocky Ridge PM3 & $03-09-76$ & 5,995 & 1,805 & $1,639-1,805$ & 1,595 & $\begin{array}{l}\text { Water chemistry, } \\
\text { withdrawals }\end{array}$ \\
\hline Rough Rock PM5 & $06-27-64$ & 6,299 & 1,420 & $1,180-1,420$ & 1,156 & $\begin{array}{l}\text { Water chemistry, } \\
\text { withdrawals }\end{array}$ \\
\hline Second Mesa PM2 & ${ }^{3} 10-00-68$ & 5,777 & 1,090 & $740-1,090$ & 720 & $\begin{array}{l}\text { Water chemistry, } \\
\text { withdrawals }\end{array}$ \\
\hline Tuba City NTUA 3 & ${ }^{3} 10-00-71$ & 5,176 & 442 & $142-442$ & 34 & $\begin{array}{l}\text { Water level, } \\
\text { withdrawals }\end{array}$ \\
\hline Tuba City Rare Metals 2 & ${ }^{3} 09-00-55$ & 5,108 & 705 & $100-705$ & 255 & Water level \\
\hline
\end{tabular}

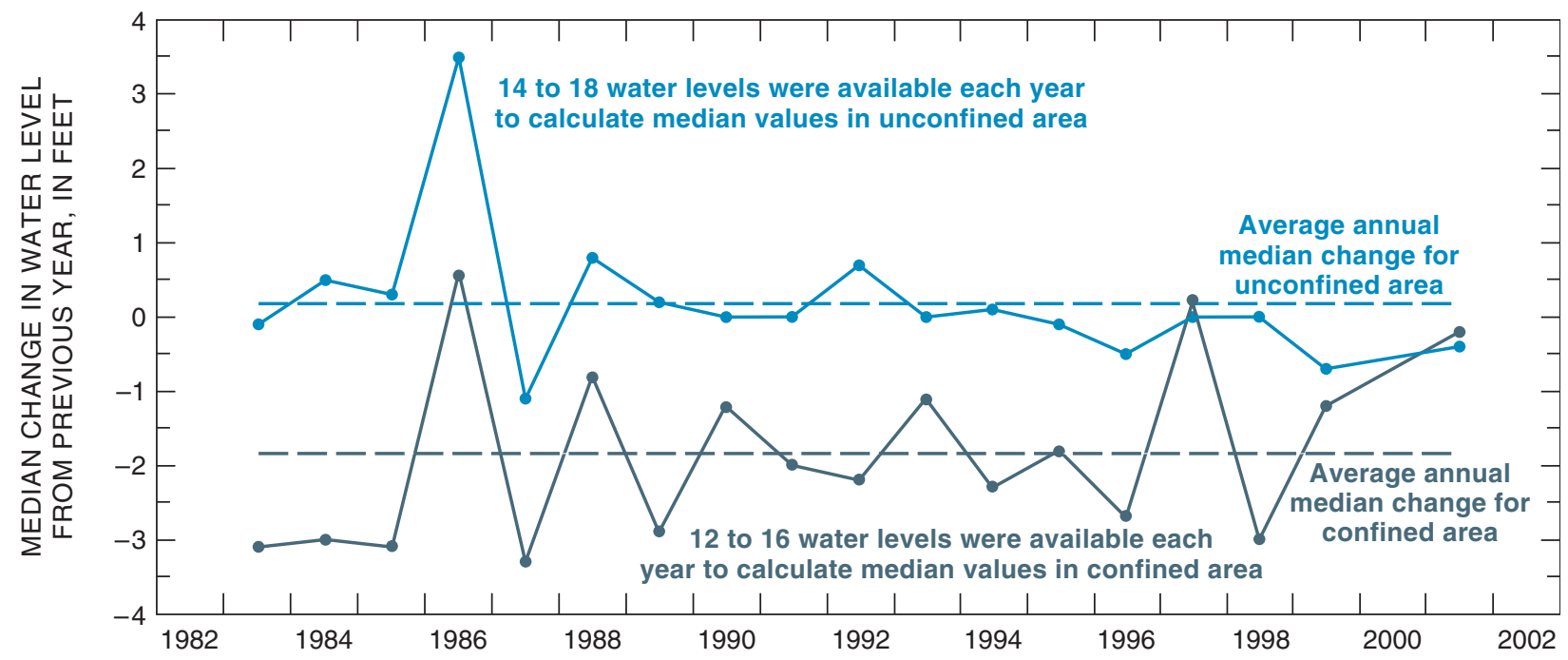

Figure 6. Annual water-level changes for observation wells completed in the N aquifer, Black Mesa area, Arizona, $1983-2001$. 


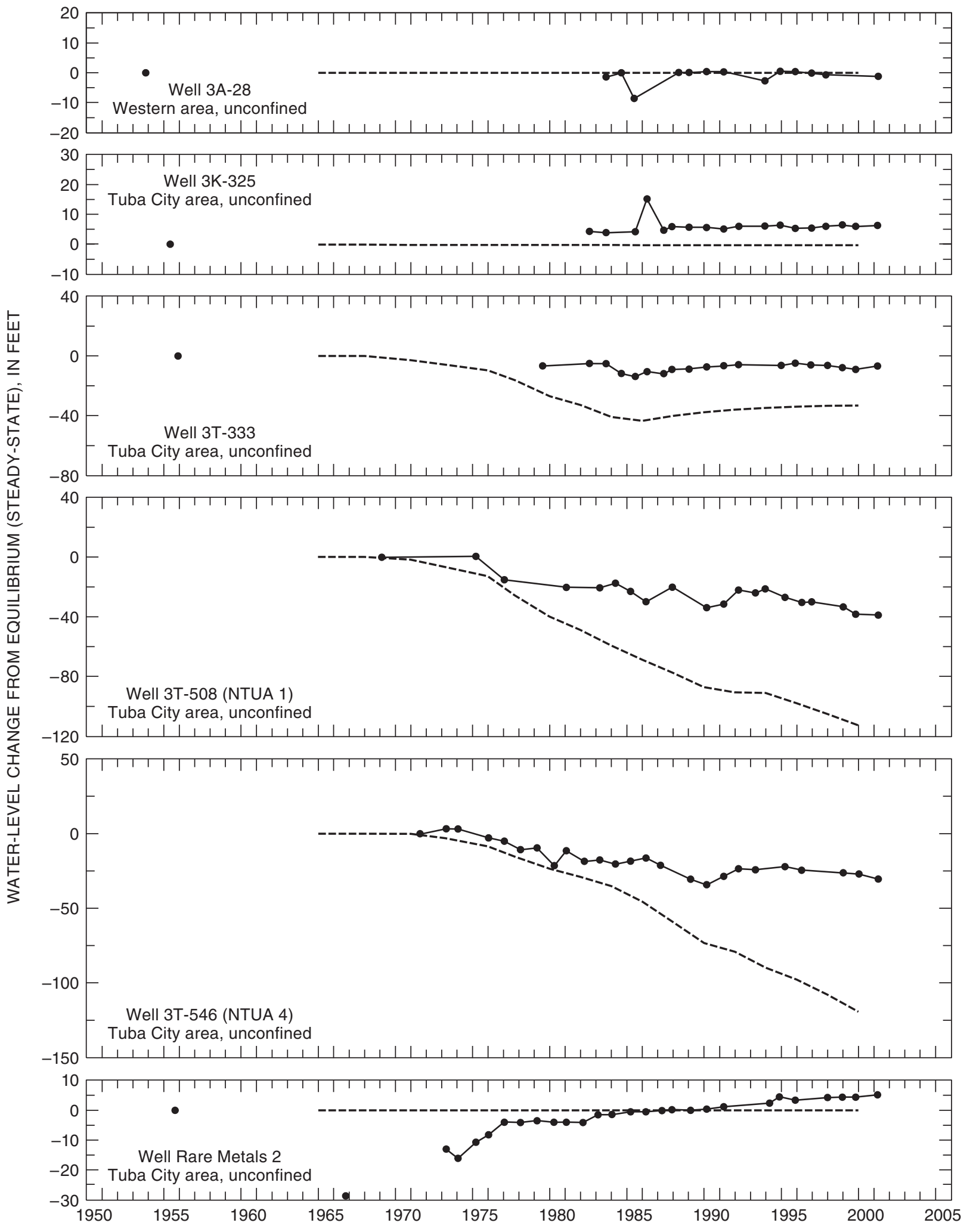

Figure 7. Observed water-level changes, 1950-2001 (circles and solid line), and simulated water-level changes, 1965-99 (dashed line), for annual observation-well network, Black Mesa area, Arizona. 


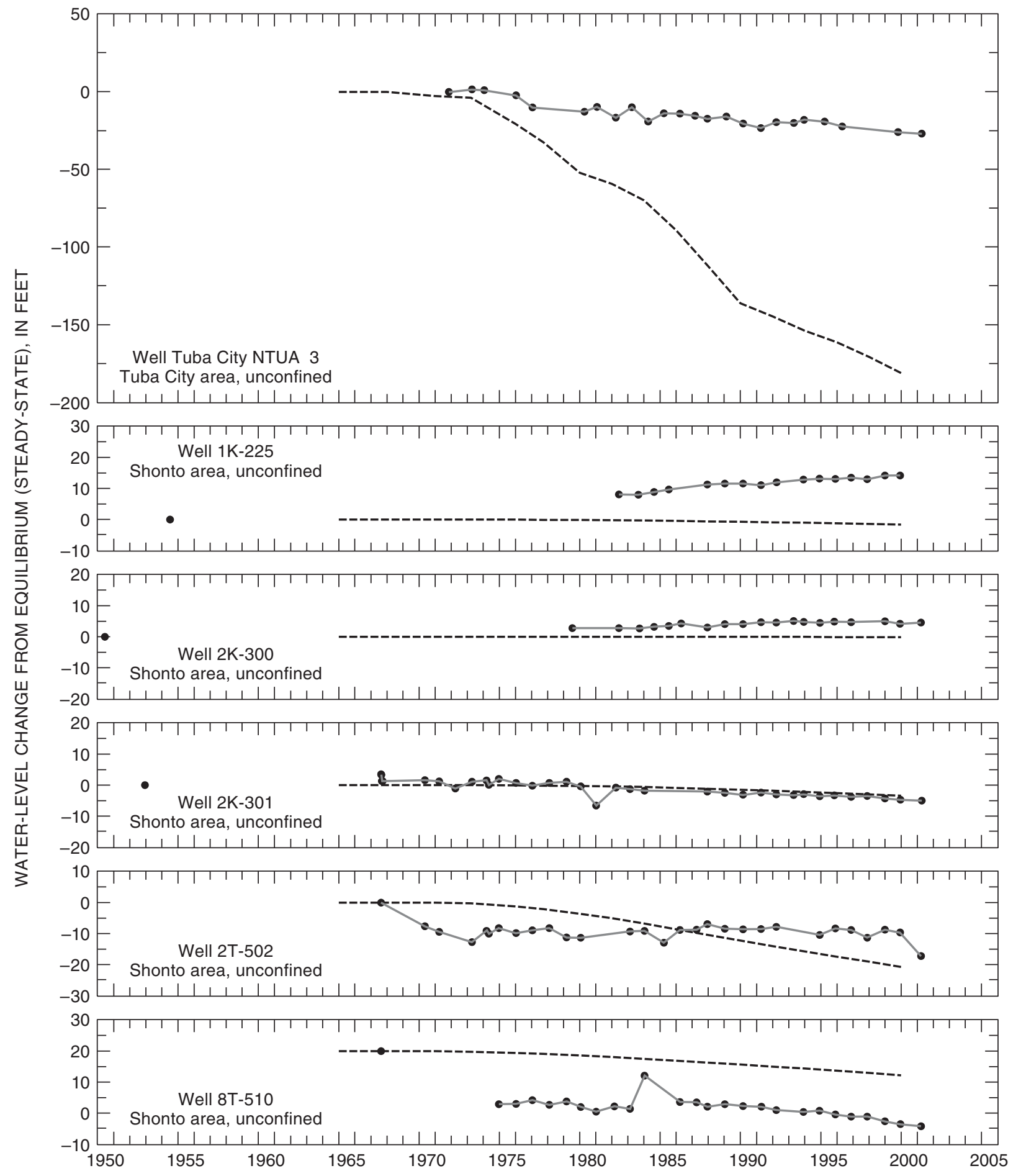

Figure 7. Continued. 

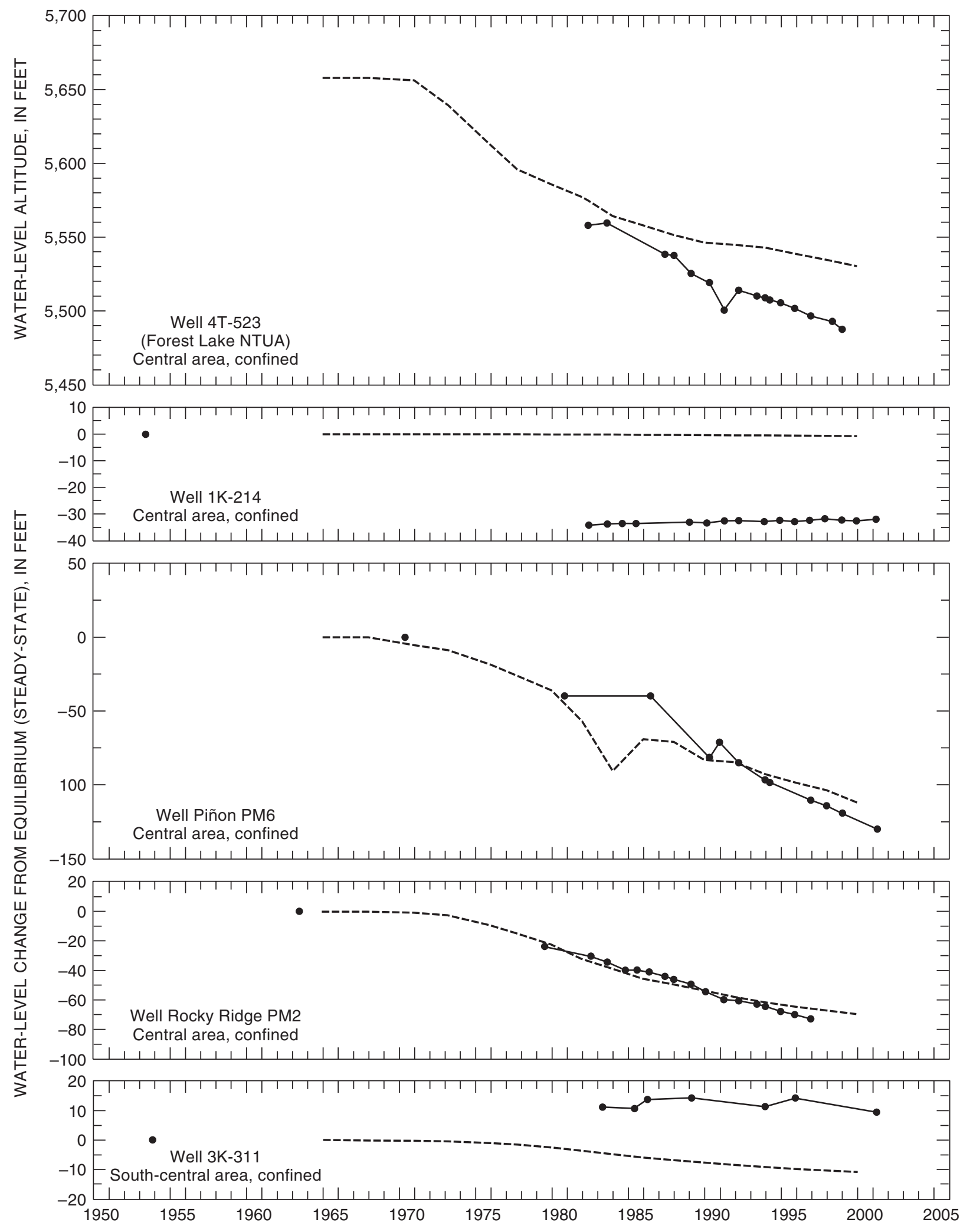

Figure 7. Continued. 


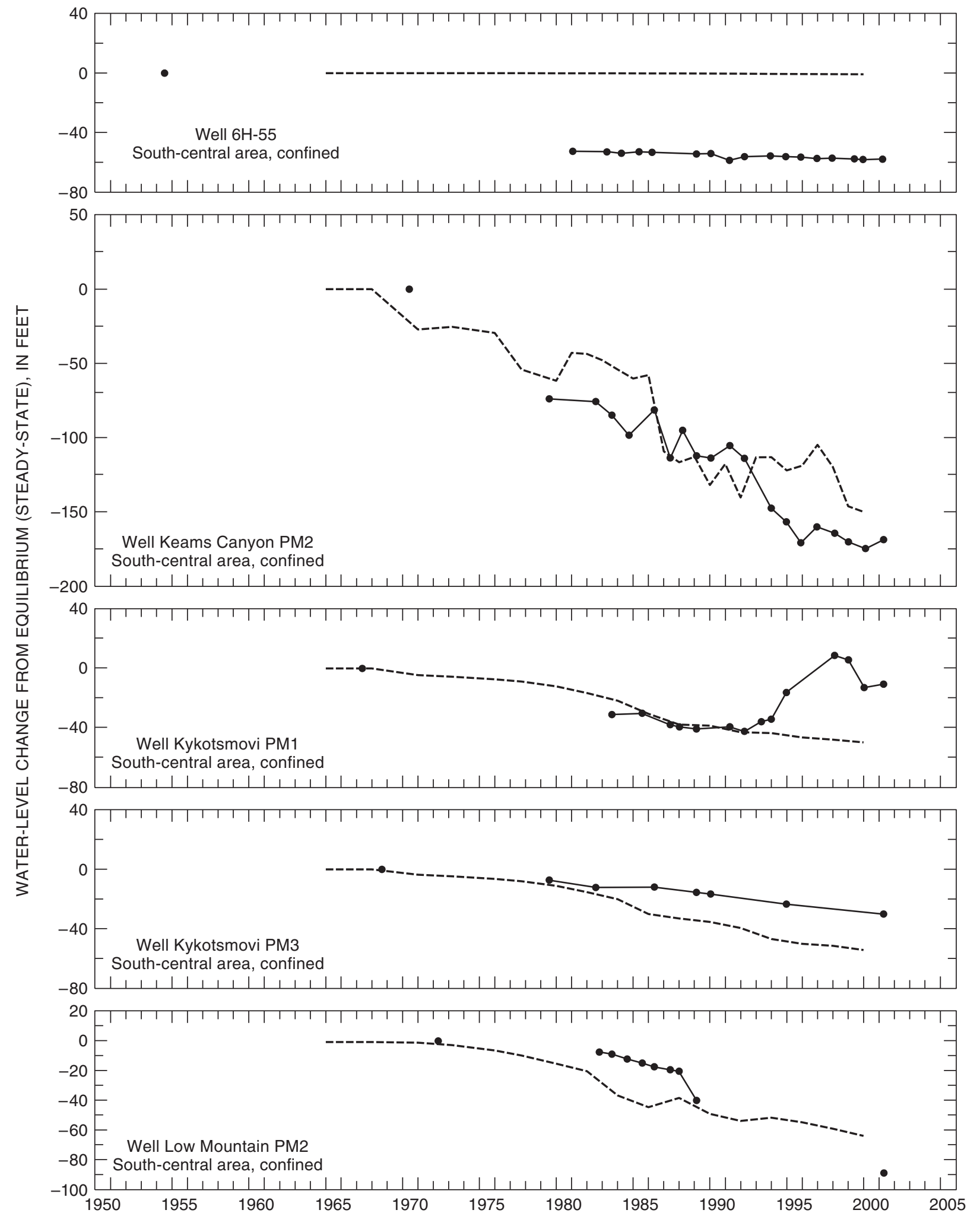

Figure 7. Continued. 


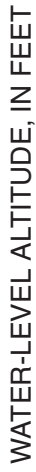
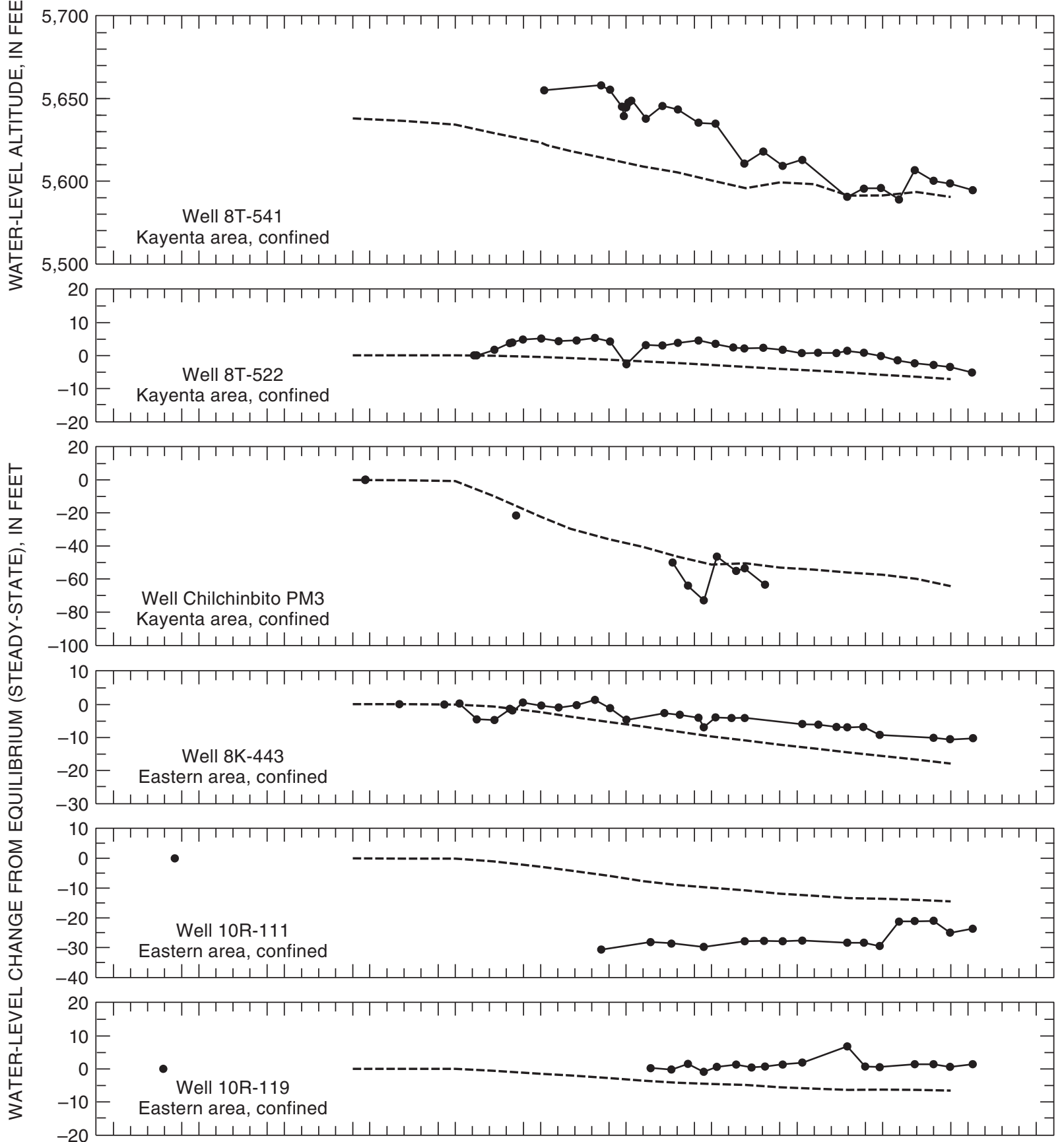

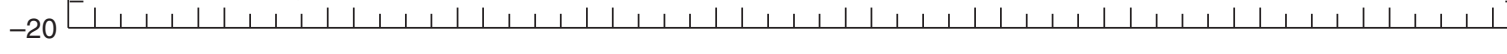

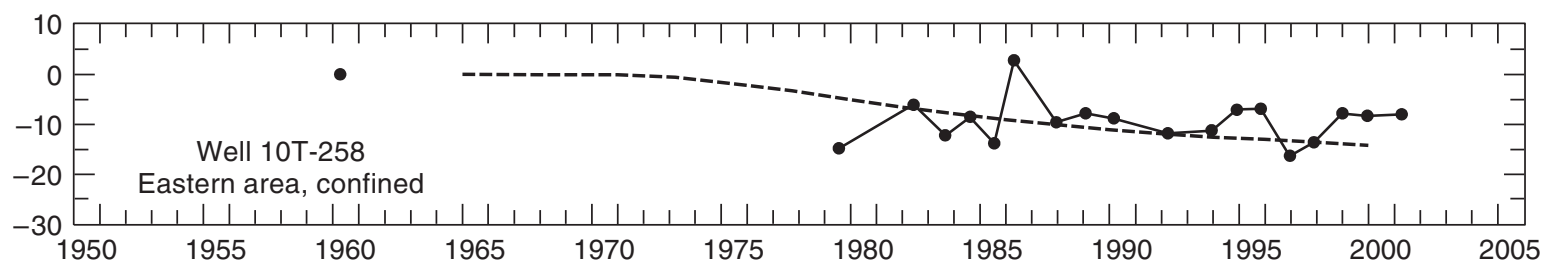

Figure 7. Continued. 


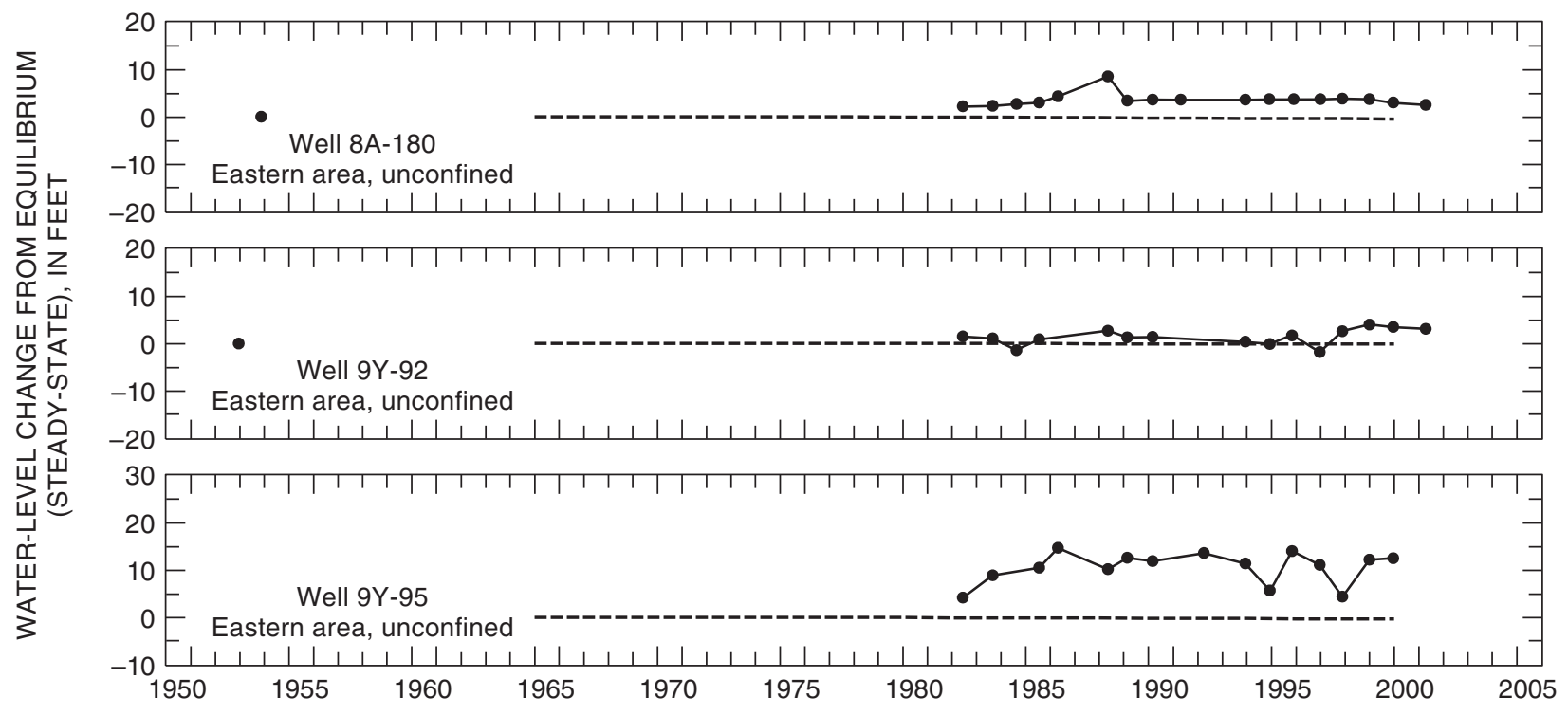

Figure 7. Continued. 


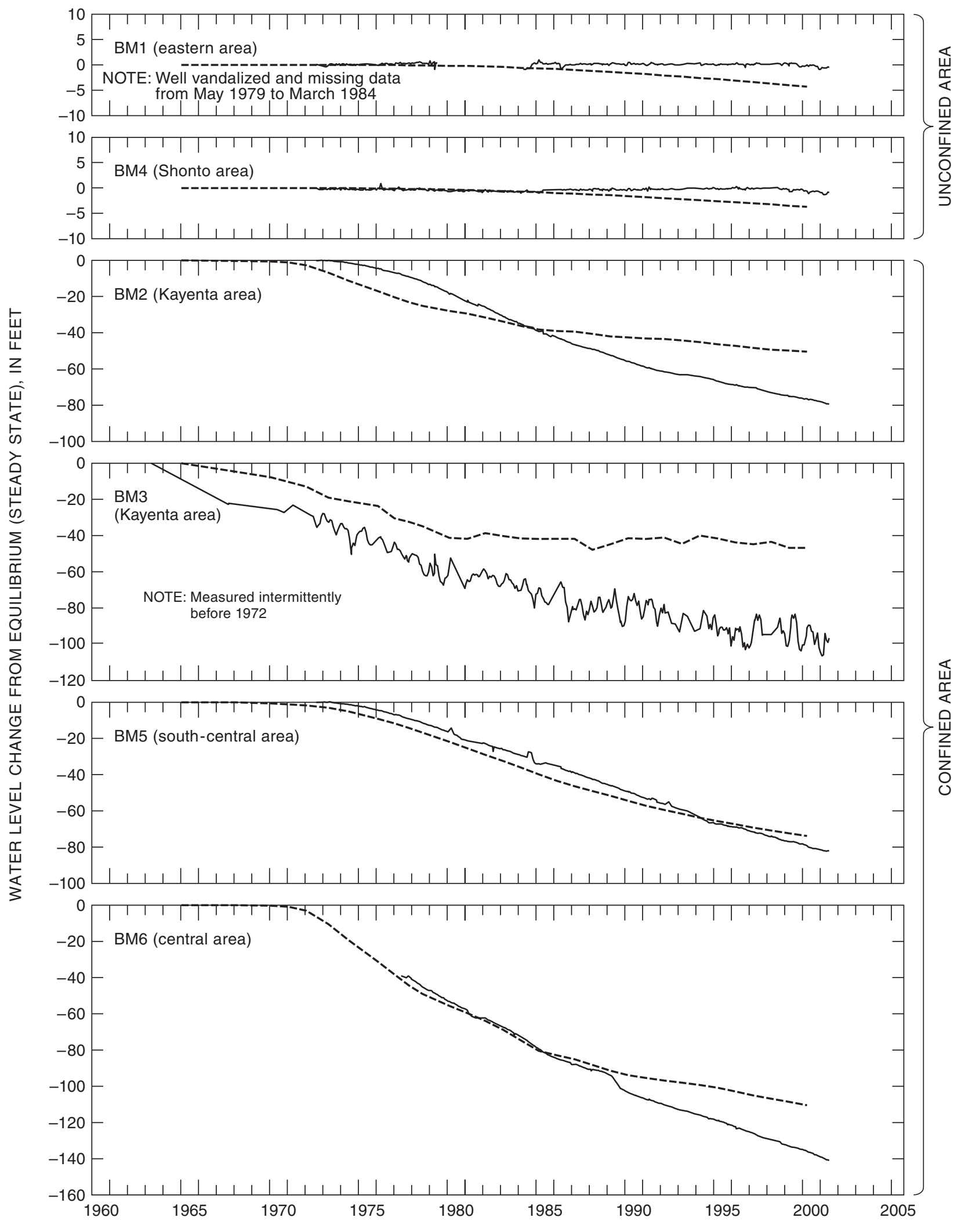

Figure 8. Observed water-level changes in continuous-record observation wells, BM1-BM6, 1963-2001 (solid line), and simulated water-level changes 1965-99 (dashed line), Black Mesa area, Arizona. 


\section{Spring Discharge from the $\mathbf{N}$ Aquifer}

Ground water in the $\mathrm{N}$ aquifer discharges from many springs around the margins of the Black Mesa area. Discharge from selected springs is measured annually and compared to discharge from previous years to determine changes in spring discharge over time. In March-June 2001, discharge was measured at four springs (table 6). Three springs are on the west or southwest side of the Black Mesa area and one is on the northeast side (fig. 9). The discharge from these four springs represents only a small fraction of the total spring discharge from the $\mathrm{N}$ aquifer.
In 2001, measured discharges were $0.2 \mathrm{gal} / \mathrm{min}$ from Burro Spring, $26.8 \mathrm{gal} / \mathrm{min}$ from the unnamed spring near Dennehotso, $13.7 \mathrm{gal} / \mathrm{min}$ from Moenkopi School Spring, and $37 \mathrm{gal} / \mathrm{min}$ from Pasture Canyon Spring. Compared to spring discharges in 1999, discharges decreased by 33 percent for Burro Spring, increased by 81 percent for the unnamed spring near Dennehotso, increased by 3 percent for Moenkopi School Spring, and decreased by 5 percent for Pasture Canyon Spring. The discharge measured at all four springs represents only part of the total discharge from the springs. Because of separate seeps and problematic measuring conditions, it would be difficult to measure the total discharge at those sites.

Table 6. Discharge measurements of selected springs, Black Mesa area, Arizona, 1952-2001

\begin{tabular}{|c|c|c|c|c|c|c|c|}
\hline $\begin{array}{l}\text { U.S. Bureau of } \\
\text { Indian Affairs } \\
\text { site number }\end{array}$ & Rock formation(s) & $\begin{array}{c}\text { Date of } \\
\text { measurement }\end{array}$ & $\begin{array}{l}\text { Discharge, } \\
\text { in gallons } \\
\text { per minute }\end{array}$ & $\begin{array}{l}\text { U.S. Bureau of } \\
\text { Indian Affairs } \\
\text { site number }\end{array}$ & Rock formation(s) & $\begin{array}{c}\text { Date of } \\
\text { measurement }\end{array}$ & $\begin{array}{l}\text { Discharge, } \\
\text { in gallons } \\
\text { per minute }\end{array}$ \\
\hline \multicolumn{4}{|c|}{ Burro Spring } & \multicolumn{4}{|c|}{ Moenkopi School Spring } \\
\hline \multirow[t]{9}{*}{ 6M-31 } & \multirow[t]{9}{*}{ Navajo Sandstone } & $12-15-89$ & 0.4 & \multirow[t]{12}{*}{$3 \mathrm{GS}-77-6$} & \multirow[t]{12}{*}{ Navajo Sandstone $^{1}$} & $05-16-52$ & 40 \\
\hline & & $12-13-90$ & .4 & & & $04-22-87$ & 216 \\
\hline & & $03-18-93$ & .3 & & & $11-29-88$ & ${ }^{2} 12.5$ \\
\hline & & $12-08-94$ & .2 & & & $02-21-91$ & ${ }^{2} 13.5$ \\
\hline & & $12-17-96$ & .4 & & & 04-07-93 & ${ }^{2} 14.6$ \\
\hline & & $12-30-97$ & .2 & & & 12-07-94 & ${ }^{2} 12.9$ \\
\hline & & $12-08-98$ & .3 & & & $12-04-95$ & ${ }^{2} 12.1$ \\
\hline & & $12-07-99$ & .3 & & & $12-16-96$ & ${ }^{2} 10$ \\
\hline & & $04-02-01$ & .2 & & & $12-17-97$ & ${ }^{2} 13.1$ \\
\hline \multicolumn{4}{|c|}{ Unnamed spring near Dennehotso } & & & $12-08-98$ & ${ }^{2} 12.0$ \\
\hline \multirow[t]{12}{*}{$8 \mathrm{~A}-224$} & Navajo Sandstone & $10-06-54$ & ${ }^{3} 1$ & & & 12-13-99 & ${ }^{2} 13.3$ \\
\hline & & $06-27-84$ & 32 & & & $03-12-01$ & ${ }^{2} 13.7$ \\
\hline & & $11-17-87$ & 35 & \multicolumn{4}{|c|}{ Pasture Canyon Spring } \\
\hline & & $03-26-92$ & 16 & \multirow[t]{9}{*}{$3 \mathrm{~A}-5$} & \multirow[t]{9}{*}{$\begin{array}{l}\text { Navajo Sandstone, } \\
\text { alluvium }\end{array}$} & $11-18-88$ & ${ }^{4} 211$ \\
\hline & & $10-22-93$ & 14.4 & & & 03-24-92 & ${ }^{4} 233$ \\
\hline & & $12-05-95$ & 17 & & & $10-12-93$ & ${ }^{4} 211$ \\
\hline & & 12-19-96 & 15.7 & & & $12-04-95$ & 538 \\
\hline & & $12-31-97$ & 25.6 & & & $12-16-96$ & ${ }^{5} 38$ \\
\hline & & 12-14-98 & 21.0 & & & 12-17-97 & 540 \\
\hline & & $12-15-99$ & 14.8 & & & $12-10-98$ & 539 \\
\hline & & \multirow[t]{2}{*}{$03-14-01$} & \multirow[t]{2}{*}{26.8} & & & $12-21-99$ & 539 \\
\hline & & & & & & $06-12-01$ & 537 \\
\hline
\end{tabular}




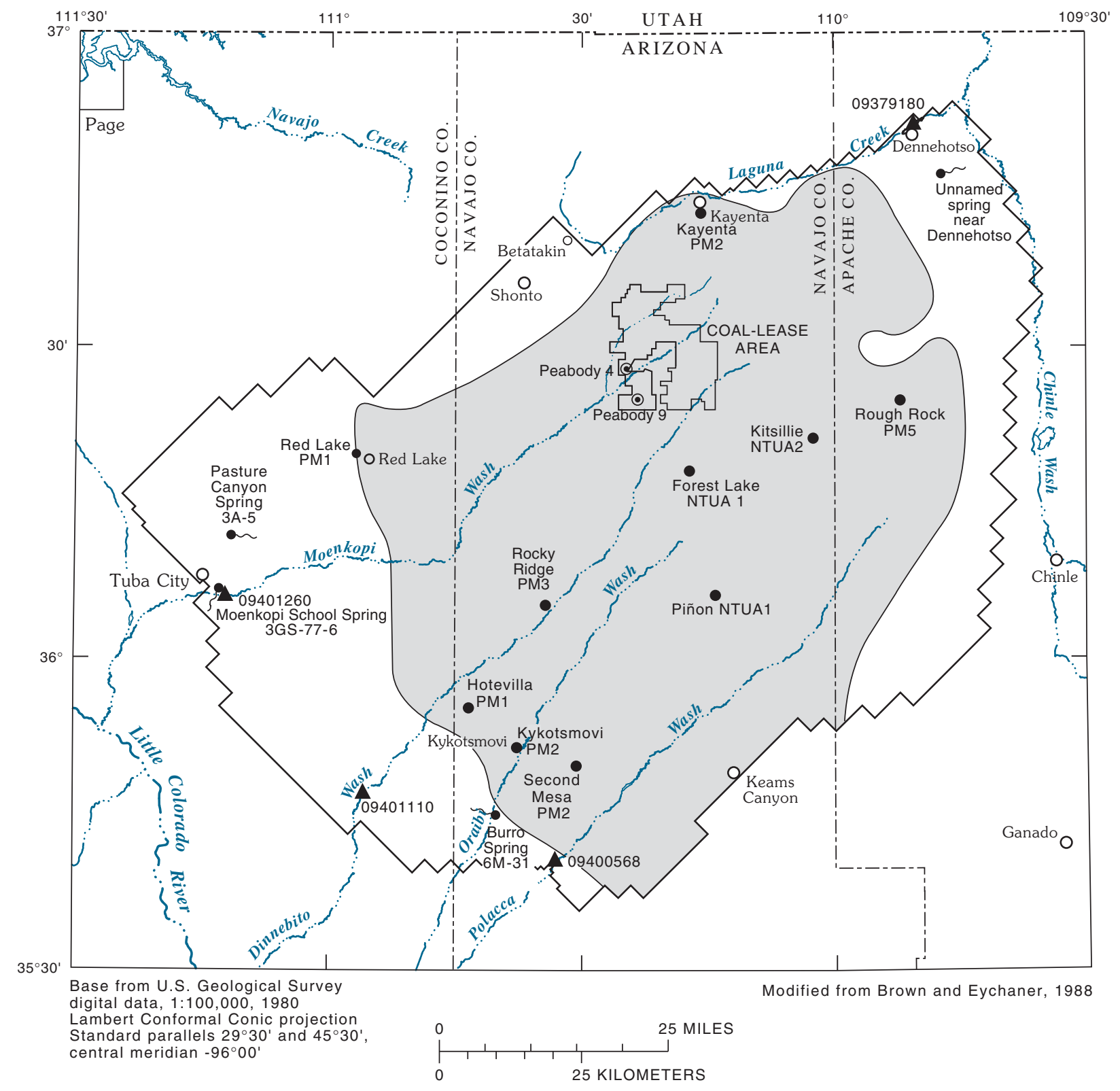

EXPLANATION

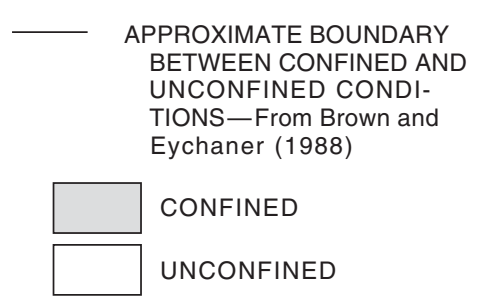

Rough Rock
PM5 $\bullet$ MUNICIPAL WELL FROM WHICH
WATER-CHEMISTRY SAMPLE
WAS COLLECTED-Rough
Rock PM5 is well name

$\odot$ INDUSTRIAL WELL FROM WHICH WATER-CHEMISTRY SAMPLE WAS COLLECTED-Peabody 9 is well number

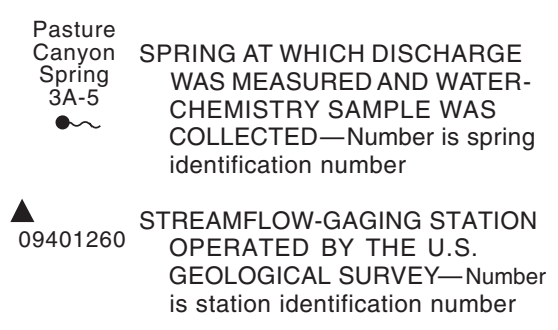

BOUNDARY OF MATHEMATICAL

MODEL - From Brown and

Eychaner (1988)

Figure 9. Surface-water and water-chemistry data-collection sites, Black Mesa area, Arizona, 2000-2001. 
Long-term changes in spring discharge can be evaluated for the entire record at Burro Spring but can be evaluated only for parts of the records for the other three springs because discharge measuring points changed during the periods of record (table 6). Consistent measuring points are available for 1992 2001 at the unnamed spring near Dennehotso, for 1987-2001 at Moenkopi School Spring, and for 19952001 at Pasture Canyon Spring. For the consistent periods of record at Burro Spring, the unnamed spring near Dennehotso, and Moenkopi School Spring, there are no significant trends in the discharge; all p-values from a Kendall's tau statistical test are greater than 0.05. A statistical test was not done for Pasture Canyon Spring because its record is too short (six discharge measurements).

\section{Surface-Water Discharge}

Surface-water discharge in the study area includes ground-water discharge and direct or shallow subsurface runoff of rainfall or snowmelt. Ground water discharges to surface water at a fairly constant rate throughout the year. In contrast, the amount of rainfall or snowmelt runoff varies widely throughout the year. In the winter and spring, the amount and timing of snowmelt runoff is a result of the temporal variation in snow accumulation, air temperatures, and rate of snowmelt. Although most rainfall runoff is in the summer, rainfall can cause surface-water discharge any time of the year. The amount and timing of rainfall runoff is a result of the intensity and duration of thunderstorms in the summer and cyclonic storms in the fall, winter, and spring.

Data on surface-water discharge have been collected continuously at selected streams each year of the monitoring program. The discharge data provide useful information about ground-water discharge and about runoff from rainfall and snowmelt. In this study, the total discharge in streams is roughly separated into ground-water discharge and runoff so that the temporal trends in ground-water discharge can be monitored.

In 2000, continuous-record discharge data were collected at four streamflow-gaging stations (tables 710). The gaging stations and their starting dates of operation are: Moenkopi Wash in July 1976, Laguna Creek in July 1996, Dinnebito Wash in June 1993, and Polacca Wash in April 1994 (fig. 9, table 11).

The annual average discharges for the four gaging stations vary considerably during their periods of record (fig. 10). The records for Laguna Creek, Dinnebito Wash, and Polacca Wash are too short to discern any trends. There is no significant trend in the annual average discharges for Moenkopi Wash from 1977 to 2000; a Kendall's tau statistical test resulted in a p-value of 0.172 .

The ground-water discharge component of total flow at the four streamflow-gaging stations was roughly estimated by computing the median flow for four winter months - November, December, January, and February. Ground-water discharge is assumed to be constant the entire year, and the median winter flow is assumed to represent this constant annual ground-water discharge. Most flow during the winter is ground-water discharge because rainfall and snowmelt runoff are minimal. Most of the precipitation in the winter falls as snow, and the cold temperatures prevent appreciable snowmelt. Also, evapotranspiration from streams is at a minimum during the winter. During the summer, much of the flow in streams evaporates or is transpired by plants. The median flow for November, December, January, and February, rather than the average flow, is used to estimate ground-water discharge because the median is less affected by occasional winter runoff. The 120 consecutive daily mean flows for those four months were used to compute the median flow.

The median flow for November, December, January, and February is an index of ground-water discharge rather than an absolute estimate of discharge. A more rigorous and accurate estimate would include detailed evaluations of streamflow hydrographs, flows into and out of bank storage, gain and loss of streamflow as it moves down the stream channel, and interaction of ground water in the $\mathrm{N}$ aquifer with ground water in the shallow alluvial aquifers in the stream valleys. The median winter flow, however, is useful as a consistent index for evaluating possible time trends in ground-water discharge.

In the 2000 water year (October 1 to September 30), median flows for November, December, January, and February were $2.2 \mathrm{ft}^{3} / \mathrm{s}$ for Moenkopi Wash, $1.6 \mathrm{ft}^{3} / \mathrm{s}$ for Laguna Creek, $0.32 \mathrm{ft}^{3} / \mathrm{s}$ for Dinnebito Wash, and $0.17 \mathrm{ft}^{3} / \mathrm{s}$ for Polacca Wash. There is no significant trend in the median winter flows for Moenkopi Wash from 1977 to 2000; a Kendall's tau statistical test resulted in a p-value of 0.819 . The records for the other three streams are too short for a statistical analysis of trends. The median winter flows for Dinnebito Wash and Polacca Wash, however, appear to have decreased during the last 6 years. This decrease in flows may be related to lessthan-average precipitation and ground-water recharge during the last 6 years. Annual precipitation at Betatakin, about 15 miles west of Kayenta, has been less than average for 4 of the last 6 years (figure 10). 
Table 7. Discharge data, Moenkopi Wash at Moenkopi, Arizona (09401260), calendar year 2000

\section{DISCHARGE, IN CUBIC FEET PER SECOND, CALENDAR YEAR 2000}

DAILY MEAN VALUES

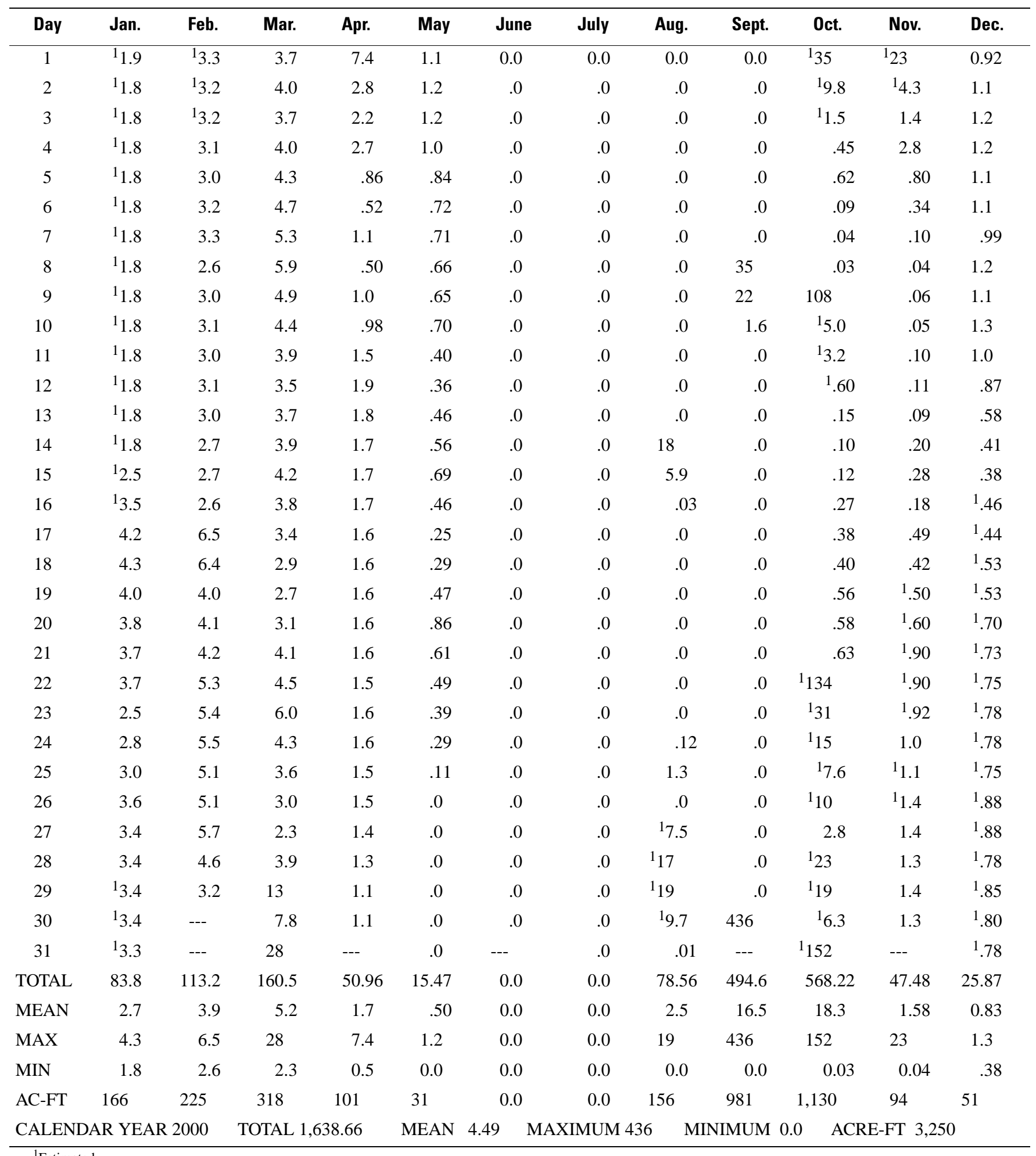

${ }^{1}$ Estimated. 
Table 8. Discharge data, Laguna Creek at Dennehotso, Arizona (09379180), calendar year 2000

$[--$, no data]

DISCHARGE, IN CUBIC FEET PER SECOND, CALENDAR YEAR 2000

DAILY MEAN VALUES

\begin{tabular}{|c|c|c|c|c|c|c|c|c|c|c|c|c|}
\hline Day & Jan. & Feb. & Mar. & Apr. & May & June & July & Aug. & Sept. & Oct. & Nov. & Dec. \\
\hline 1 & 13.0 & ${ }^{1} 5.6$ & 1.1 & 0.69 & 0.0 & 0.0 & 0.0 & 0.0 & ${ }^{1} 0.0$ & ${ }^{1} 0.04$ & ${ }^{1} 16$ & ${ }^{1} 2.8$ \\
\hline 2 & $1_{3.1}$ & $1_{2.5}$ & 1.5 & .42 & .0 & .0 & .0 & .0 & ${ }^{1} .0$ & ${ }^{1} .0$ & ${ }^{1} 16$ & ${ }^{1} 6.0$ \\
\hline 3 & ${ }^{1} 1.1$ & $1_{2.5}$ & 1.6 & .41 & .0 & .0 & .0 & .0 & ${ }^{1} .0$ & ${ }^{1} .0$ & 11 & $1_{4.0}$ \\
\hline 4 & ${ }^{1} 1.1$ & 6.7 & 1.5 & .41 & .0 & .0 & .0 & .0 & .0 & .0 & 6.7 & 1.3 \\
\hline 5 & ${ }^{1} 1.1$ & 7.5 & 1.5 & 1.7 & .0 & .0 & .0 & .0 & .0 & .0 & 6.1 & 1.4 \\
\hline 6 & ${ }^{1} 1.5$ & 6.1 & 1.5 & 1.7 & .0 & .0 & .0 & .0 & .0 & .0 & 5.2 & 2.6 \\
\hline 7 & .38 & 5.3 & 2.0 & 1.1 & .0 & .0 & .0 & .0 & .0 & .0 & 4.6 & 2.2 \\
\hline 8 & .11 & 4.8 & 1.9 & .40 & .0 & .0 & .0 & .0 & .0 & .0 & 3.4 & 2.9 \\
\hline 9 & .07 & 4.9 & 1.5 & .33 & .0 & .0 & .0 & .0 & .0 & .0 & 1.9 & ${ }^{1} 2.0$ \\
\hline 10 & .08 & 4.7 & 1.2 & .24 & .0 & .0 & .0 & .0 & .0 & 22 & 2.9 & ${ }^{1} 1.6$ \\
\hline 11 & .10 & 4.9 & .64 & .13 & .0 & .0 & .0 & .0 & .0 & 7.8 & ${ }^{1} 2.8$ & ${ }^{1} 1.3$ \\
\hline 12 & ${ }^{1} .50$ & 4.8 & .45 & .08 & .0 & .0 & .0 & .0 & .0 & 1.6 & $1_{3.0}$ & 1.4 \\
\hline 13 & ${ }^{1} 1.0$ & 4.4 & .60 & .03 & .0 & .0 & .0 & .0 & .0 & .60 & 1.3 & 1.4 \\
\hline 14 & ${ }^{1} 1.3$ & 3.8 & .56 & .0 & .0 & .0 & .0 & .0 & .0 & .24 & $1_{2.0}$ & 1.3 \\
\hline 15 & $1_{3.0}$ & 3.2 & .55 & .0 & .0 & .0 & .0 & .0 & .0 & .29 & ${ }^{1} 4.5$ & 3.3 \\
\hline 16 & $1_{2.5}$ & 2.7 & .48 & .0 & .0 & .0 & .0 & .0 & .0 & .36 & 2.2 & ${ }^{1} 1.6$ \\
\hline 17 & 5.7 & 2.5 & .38 & .0 & .0 & .0 & .0 & .0 & .0 & .51 & $1_{2.7}$ & ${ }^{1} .60$ \\
\hline 18 & ${ }^{1} 5.0$ & 1.3 & .35 & .0 & .0 & .0 & .0 & .0 & .0 & .65 & ${ }^{1} 2.0$ & ${ }^{1} .70$ \\
\hline 19 & 11 & 4.3 & .30 & .0 & .0 & .0 & .0 & .0 & .0 & .61 & 1.4 & ${ }^{1} .70$ \\
\hline 20 & ${ }^{1} 12$ & 2.4 & .37 & .0 & .0 & .0 & .0 & .0 & .0 & .62 & ${ }^{1} 1.5$ & ${ }^{1} .70$ \\
\hline 21 & 13 & 1.8 & .86 & .0 & .0 & .0 & .0 & .0 & .0 & .65 & ${ }^{1} 1.5$ & ${ }^{1} 1.3$ \\
\hline 22 & 10 & 1.6 & 1.3 & .0 & .0 & .0 & .0 & .0 & .0 & 4.0 & ${ }^{1} 2.6$ & ${ }^{1} .70$ \\
\hline 23 & 12 & 1.4 & 2.6 & .0 & .0 & .0 & .0 & .0 & .0 & 651 & ${ }^{1} 6.0$ & ${ }^{1} .70$ \\
\hline 24 & 8.6 & 1.3 & 1.4 & .0 & .0 & .0 & .0 & .0 & .0 & 114 & 17.0 & ${ }^{1} .70$ \\
\hline 25 & 7.3 & .46 & $1_{2.0}$ & .0 & .0 & .0 & .0 & ${ }^{1} .0$ & .0 & 19 & 17.0 & $1_{2.5}$ \\
\hline 26 & 7.9 & .08 & $1_{3.0}$ & .0 & .0 & .0 & .0 & ${ }^{1} 3.3$ & .0 & 8.8 & $1_{3.0}$ & ${ }^{1} 1.5$ \\
\hline 27 & 11 & .06 & ${ }^{1} 1.0$ & .0 & .0 & .0 & .0 & 10 & .0 & 6.1 & $1_{3.5}$ & 1.8 \\
\hline 28 & ${ }^{1} 5.0$ & 2.9 & $1_{2.0}$ & .0 & .0 & .0 & .0 & 3.0 & .0 & 5.2 & ${ }^{1} 4.7$ & 1.6 \\
\hline 29 & $1_{3.3}$ & 1.2 & ${ }^{1} 1.0$ & .0 & .0 & .0 & .0 & 34 & .0 & 6.4 & 17.3 & 1.1 \\
\hline 30 & ${ }^{1} 1.0$ & --- & ${ }^{1} .60$ & .0 & .0 & .0 & .0 & 17 & ${ }^{1} 1.4$ & 18.4 & $1_{4.0}$ & 1.6 \\
\hline 31 & ${ }^{1} .20$ & --- & .65 & --- & .0 & --- & .0 & ${ }^{1} .46$ & --- & 9.9 & --- & $1_{2.5}$ \\
\hline TOTAL & 132.94 & 95.70 & 36.39 & 7.64 & 0.0 & 0.0 & 0.0 & 67.76 & 1.40 & 868.77 & 143.8 & 55.80 \\
\hline MEAN & 4.3 & 3.3 & 1.2 & .25 & 0.0 & 0.0 & 0.0 & 2.2 & .05 & 28.0 & 4.8 & 1.8 \\
\hline MAX & 13 & 7.5 & 3.0 & 1.7 & 0.0 & 0.0 & 0.0 & 34 & 1.4 & 651 & 16 & 6.0 \\
\hline MIN & .07 & .06 & .30 & 0.0 & 0.0 & 0.0 & 0.0 & 0.0 & 0.0 & 0.0 & 1.3 & 0.60 \\
\hline AC-FT & 264 & 190 & 72 & 15 & 0.0 & 0.0 & 0.0 & 134 & 2.8 & 1,720 & 285 & 111 \\
\hline \multicolumn{3}{|c|}{ CALENDAR YEAR 2000} & TOTAL 1, & 0.20 & MEAN & $3.86 \mathrm{~N}$ & XIMUM & 651 & IMUM & \multicolumn{3}{|c|}{ ACRE-FT 2,797 } \\
\hline
\end{tabular}


Table 9. Discharge data, Dinnebito Wash near Sand Springs, Arizona (09401110), calendar year 2000

\section{DISCHARGE, IN CUBIC FEET PER SECOND, CALENDAR YEAR 2000} DAILY MEAN VALUES

\begin{tabular}{|c|c|c|c|c|c|c|c|c|c|c|c|c|}
\hline Day & Jan. & Feb. & Mar. & Apr. & May & June & July & Aug. & Sept. & Oct. & Nov. & Dec. \\
\hline 1 & 0.36 & 0.32 & 0.40 & 0.41 & 0.27 & 0.26 & 0.23 & 0.12 & 0.57 & 0.21 & 3.2 & 0.34 \\
\hline 2 & .34 & .32 & .46 & .38 & .28 & .25 & .22 & .13 & .23 & .20 & .58 & .36 \\
\hline 3 & .29 & .33 & .39 & .36 & .28 & .25 & .20 & .11 & .66 & .21 & .26 & .34 \\
\hline 4 & .29 & .36 & .38 & .36 & .28 & .27 & .18 & .11 & .22 & .27 & .33 & .33 \\
\hline 5 & .32 & .33 & .42 & .35 & .24 & .26 & .18 & .12 & .13 & .25 & .30 & .36 \\
\hline 6 & .30 & .19 & .40 & .32 & .24 & .26 & .19 & .12 & .14 & .24 & .22 & .34 \\
\hline 7 & .29 & .19 & .46 & .30 & .23 & .25 & .20 & .12 & .18 & .24 & .23 & .37 \\
\hline 8 & .30 & .20 & .34 & .33 & .24 & .23 & .20 & .42 & .15 & .22 & .24 & .40 \\
\hline 9 & .32 & .55 & .56 & .32 & .27 & .22 & .22 & .54 & .13 & .23 & .27 & .37 \\
\hline 10 & .35 & .32 & .38 & .32 & .26 & .22 & .26 & .18 & .12 & .26 & .28 & .37 \\
\hline 11 & .37 & .32 & .38 & .35 & .19 & .22 & .21 & .15 & .12 & .23 & .44 & .35 \\
\hline 12 & .37 & .29 & .43 & .36 & .18 & .22 & .20 & .22 & .12 & .24 & .33 & .37 \\
\hline 13 & .37 & .30 & .42 & .35 & .21 & .21 & .20 & .16 & .12 & .26 & .26 & .38 \\
\hline 14 & .38 & .32 & .42 & .29 & .27 & .20 & .20 & .13 & .12 & .28 & .30 & .35 \\
\hline 15 & .38 & .32 & .40 & .30 & .24 & .20 & .21 & .13 & .12 & .27 & .30 & .33 \\
\hline 16 & .41 & .33 & .37 & .29 & .19 & .19 & .20 & .14 & .12 & .28 & .28 & .32 \\
\hline 17 & .41 & .37 & .38 & .26 & .19 & .19 & .19 & .14 & .12 & .30 & .26 & .33 \\
\hline 18 & .39 & .35 & .36 & .29 & .26 & .19 & .16 & .15 & .11 & .31 & .26 & .27 \\
\hline 19 & .41 & .35 & .39 & .32 & .30 & .19 & .15 & 7.9 & .11 & .30 & .25 & .28 \\
\hline 20 & .38 & .38 & .42 & .32 & .27 & .19 & .15 & .44 & .12 & .31 & .30 & .30 \\
\hline 21 & .36 & .34 & .58 & .29 & .26 & .18 & .13 & .25 & .11 & .33 & .33 & .35 \\
\hline 22 & .36 & .40 & .81 & .27 & .26 & .18 & .13 & .74 & .09 & 2.9 & .36 & .36 \\
\hline 23 & .32 & .38 & .82 & .28 & .25 & .18 & .13 & .41 & .09 & 18 & .35 & .37 \\
\hline 24 & .27 & .34 & .45 & .28 & .22 & .18 & .13 & .24 & .11 & 91 & .33 & .38 \\
\hline 25 & .27 & .35 & .40 & .29 & .21 & .26 & .12 & .14 & .12 & 14 & .32 & .43 \\
\hline 26 & .39 & .36 & .38 & .30 & .24 & .42 & .11 & .64 & .16 & 3.5 & .30 & .38 \\
\hline 27 & .40 & .36 & .38 & .29 & .28 & .23 & .11 & 17 & .37 & 2.2 & .34 & .31 \\
\hline 28 & .33 & .33 & .68 & .26 & .27 & .25 & .11 & 3.5 & .19 & 38 & .34 & .32 \\
\hline 29 & .33 & .36 & .45 & .23 & .20 & .26 & .11 & 11 & .16 & 14 & .33 & .33 \\
\hline 30 & .35 & --- & .46 & .24 & .25 & .26 & .12 & 18 & .16 & 4.4 & .34 & .34 \\
\hline 31 & .37 & --- & .40 & --- & .24 & --- & .12 & 2.7 & --- & 40 & --- & .33 \\
\hline TOTAL & 10.78 & 9.66 & 13.97 & 9.31 & 7.57 & 6.87 & 5.27 & 66.15 & 5.27 & 233.44 & 12.23 & 10.76 \\
\hline MEAN & 0.35 & 0.33 & 0.45 & 0.31 & 0.24 & 0.23 & 0.17 & 2.13 & 0.18 & 7.53 & 0.41 & 0.35 \\
\hline MAX & 0.41 & 0.55 & 0.82 & 0.41 & 0.30 & 0.42 & 0.26 & 18 & 0.66 & 91 & 3.2 & .43 \\
\hline MIN & 0.27 & 0.19 & 0.34 & 0.23 & 0.18 & 0.18 & 0.11 & 0.11 & 0.09 & 0.20 & .22 & .27 \\
\hline AC-FT & 21 & 19 & 28 & 18 & 15 & 14 & 10 & 131 & 10 & 463 & 24 & 21 \\
\hline \multicolumn{3}{|c|}{ CALENDAR YEAR: 2000} & TOTAL 39 & & MEAN & 1.07 & IMUM & & IMUM & $\mathrm{ACF}$ & E-FT 776 & \\
\hline
\end{tabular}


Table 10. Discharge data, Polacca Wash near Second Mesa, Arizona (09400568), calendar year 2000

[---, no data]

\section{DISCHARGE, IN CUBIC FEET PER SECOND, CALENDAR YEAR 2000}

\section{DAILY MEAN VALUES}

\begin{tabular}{|c|c|c|c|c|c|c|c|c|c|c|c|c|}
\hline Day & Jan. & Feb. & Mar. & Apr. & May & June & July & Aug. & Sept. & Oct. & Nov. & Dec. \\
\hline 1 & 0.22 & 0.20 & 0.21 & 0.78 & 0.12 & 0.07 & 0.02 & 0.01 & 0.03 & 0.01 & 4.5 & 0.06 \\
\hline 2 & .22 & .21 & .27 & .30 & .13 & .08 & .02 & .02 & .01 & .01 & 1.3 & .06 \\
\hline 3 & .16 & .22 & .21 & .22 & .12 & .08 & .02 & .02 & .01 & .01 & .52 & .06 \\
\hline 4 & .13 & .22 & .22 & .21 & .12 & .09 & .01 & .01 & .01 & .04 & .30 & .06 \\
\hline 5 & .16 & .22 & .41 & .21 & .10 & .06 & .01 & .0 & .01 & .02 & .21 & .07 \\
\hline 6 & .15 & .21 & .39 & .18 & .10 & .02 & .02 & .0 & .01 & .01 & .16 & .06 \\
\hline 7 & .12 & .21 & .69 & .18 & .09 & .03 & .02 & .0 & .02 & .01 & .13 & .06 \\
\hline 8 & .13 & .21 & .29 & .18 & .09 & .02 & .02 & .0 & .02 & .01 & .12 & .06 \\
\hline 9 & .15 & .23 & .24 & .17 & .10 & .02 & .05 & .0 & .02 & .01 & .12 & .06 \\
\hline 10 & .21 & .20 & .21 & .18 & .09 & .02 & 16 & .0 & .01 & 85 & .11 & .06 \\
\hline 11 & .21 & .21 & .18 & .18 & .07 & .02 & .46 & .0 & .01 & 9.7 & .11 & .05 \\
\hline 12 & .24 & .21 & .20 & .19 & .08 & .02 & .06 & .01 & .01 & 53 & .10 & .06 \\
\hline 13 & .24 & .21 & .21 & .18 & .10 & .02 & .04 & .01 & .01 & 1.7 & .10 & .06 \\
\hline 14 & .23 & .21 & .20 & .16 & .10 & .02 & .03 & .01 & .01 & .35 & .09 & .04 \\
\hline 15 & .23 & .21 & .21 & .17 & .09 & .02 & .02 & .07 & .01 & .08 & .09 & .05 \\
\hline 16 & .24 & .20 & .17 & .17 & .09 & .02 & .02 & .06 & .01 & .06 & .09 & .04 \\
\hline 17 & .25 & .28 & .15 & .16 & .07 & .02 & .02 & .02 & .01 & .05 & .09 & .06 \\
\hline 18 & .24 & .22 & .13 & .16 & .10 & .03 & .02 & .70 & .01 & .04 & .07 & .05 \\
\hline 19 & .22 & .22 & .13 & .16 & .11 & .03 & .01 & .31 & .01 & .03 & .07 & .05 \\
\hline 20 & .23 & .23 & .51 & .17 & .09 & .03 & .01 & .03 & .01 & .02 & .07 & ${ }^{1} .05$ \\
\hline 21 & .22 & .21 & .34 & .17 & .09 & .02 & .0 & .02 & .01 & .02 & .08 & .05 \\
\hline 22 & .21 & .24 & .69 & .17 & .08 & .02 & .0 & .03 & .0 & 47 & .08 & .06 \\
\hline 23 & .21 & .23 & .34 & .17 & .08 & .03 & .0 & .02 & .0 & 25 & .07 & .07 \\
\hline 24 & .22 & .22 & .26 & .16 & .07 & .03 & .0 & .03 & .0 & 365 & .07 & .07 \\
\hline 25 & .23 & .20 & .24 & .16 & .07 & .03 & .0 & .07 & .01 & 286 & .07 & ${ }^{1} .07$ \\
\hline 26 & .30 & .21 & .22 & .16 & .08 & .02 & .0 & 102 & .01 & 142 & .06 & ${ }^{1} .07$ \\
\hline 27 & .21 & .20 & .22 & .15 & .08 & .02 & .0 & 2.0 & .03 & 6.0 & .07 & .07 \\
\hline 28 & .20 & .19 & .47 & .13 & .08 & .03 & .0 & .62 & .01 & 11 & .07 & .07 \\
\hline 29 & .20 & .20 & .28 & .12 & .07 & .02 & .0 & 100 & .01 & 12 & .06 & .07 \\
\hline 30 & .24 & --- & .78 & .12 & .07 & .02 & .0 & 9.4 & .01 & 1.7 & .06 & .07 \\
\hline 31 & .21 & --- & 1.1 & --- & .07 & --- & .0 & .28 & --- & 5.0 & --- & .06 \\
\hline TOTAL & 6.43 & 6.23 & 10.17 & 5.82 & 2.80 & 0.96 & 16.88 & 215.75 & 0.34 & $1,050.88$ & 9.04 & 1.85 \\
\hline MEAN & 0.21 & 0.21 & 0.33 & 0.19 & 0.09 & 0.03 & 0.54 & 7.0 & 0.01 & 33.9 & 0.30 & 0.06 \\
\hline MAX & 0.30 & 0.28 & 1.1 & 0.78 & 0.13 & 0.09 & 16 & 102 & 0.03 & 365 & 4.5 & .07 \\
\hline MIN & 0.12 & 0.19 & 0.13 & 0.12 & 0.07 & 0.02 & 0.0 & 0.0 & 0.0 & 0.01 & .06 & .04 \\
\hline AC-FT & 13 & 12 & 20 & 12 & 5.6 & 1.9 & 33 & 428 & 0.7 & 2,080 & 18 & 3.7 \\
\hline \multicolumn{3}{|c|}{ CALENDAR YEAR 2000} & \multicolumn{2}{|c|}{ TOTAL $1,327.15$} & MEAN & $3.64 \quad 1$ & MAXIMUM & 365 & NIMUM & \multicolumn{3}{|c|}{$0 \quad$ ACRE-FT 2,632} \\
\hline
\end{tabular}

Table 11. Date that data collection began and drainage areas for streamflow-gaging stations, Black Mesa area, Arizona

\begin{tabular}{lccc}
\hline \multicolumn{1}{c}{ Station name } & Station number & Date data collection began & $\begin{array}{c}\text { Drainage area, } \\
\text { in square miles }\end{array}$ \\
\hline Moenkopi Wash at Moenkopi & 09401260 & July 1976 & 1,629 \\
Laguna Creek at Dennehotso & 09379180 & July 1996 & 414 \\
Dinnebito Wash near Sand Springs & 09401110 & June 1993 & 473 \\
Polacca Wash near Second Mesa & 09400568 & April 1994 & 905 \\
\hline
\end{tabular}




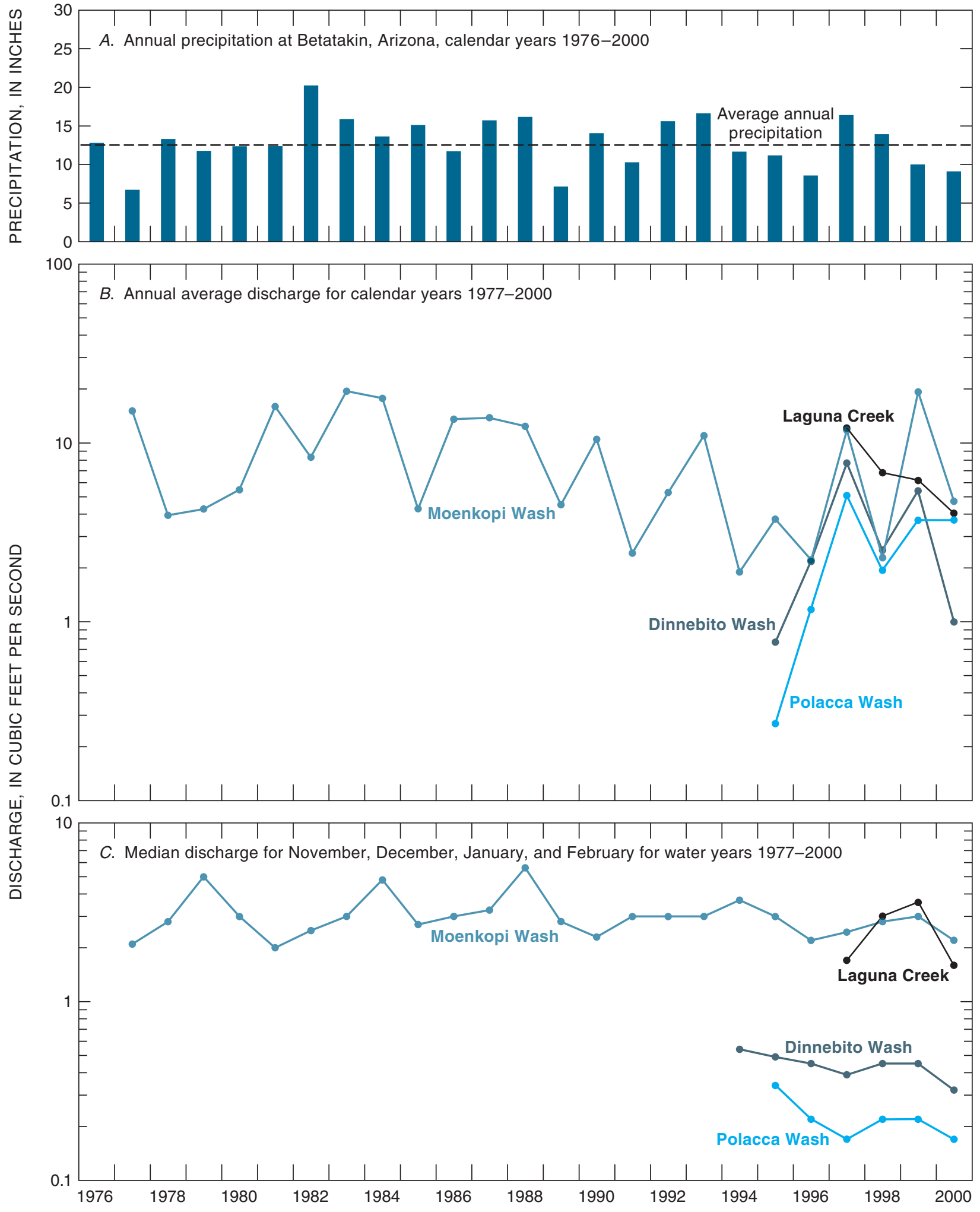

Figure 10. Annual precipitation at Betatakin, Arizona, and streamflow characteristics at Moenkopi Wash (09401260), Laguna Creek (09379180), Dinnebito Wash (09401110), and Polacca Wash (09400568), Black Mesa area, Arizona. A, Annual average precipitation at Betatakin, Arizona, calendar years 1976-2000 (National Weather Service). B, Annual average discharge for calendar years 1977-2000. C, Median discharge for November, December, January, and February for water years 1977-2000. 


\section{Water Chemistry}

Water samples are collected from selected wells and springs each year of the Black Mesa monitoring program. Field measurements are made and water samples are analyzed for major ions, nutrients, iron, boron, and arsenic. During the past 10 years, water samples have been collected from about 30 wells and 10 springs. Samples are collected from about 12 wells and 4 springs in each year of the program. Samples are collected from about the same 8 wells every year and from the other 4 wells on a rotational basis. Since 1996, samples have been collected from the same 4 springs. Long-term data for specific conductance, total dissolved solids, chloride, and sulfate for the wells and springs sampled each year are shown in the report published for that year. Historical data for other constituents for all the wells and springs are available from the USGS water-quality database or can be found in the past monitoring reports that are cited in the "Previous Investigations" section of this report.

\section{Water from Wells Completed in the N Aquifer}

In 2001, water samples were collected from 12 wells completed in the $\mathrm{N}$ aquifer. Eleven of the wells are in confined parts of the aquifer, and one well (Red Lake PM1) is on the boundary between the confined and unconfined parts (fig. 9).

The primary types of water in the $\mathrm{N}$ aquifer are calcium bicarbonate and sodium bicarbonate. Calcium bicarbonate water generally is in the recharge areas of the northern and northwestern parts of the Black Mesa area, and sodium bicarbonate water is in the area that is downgradient to the south and east; this distribution was found in the water samples collected from the 12 wells in 2001. Samples from Kayenta PM2 in the north and from Red Lake PM1 in the northwest were calcium bicarbonate water, and samples from the other 10 wells were sodium bicarbonate water (figs. 11 and 12).

Dissolved-solids concentrations in water from the 12 wells ranged from $102 \mathrm{mg} / \mathrm{L}$ at Red Lake PM1 to $628 \mathrm{mg} / \mathrm{L}$ at Rough Rock PM5 (table 12, fig. 12). Two wells had appreciably higher concentrations of dissolved solids and chloride than the other 10 wells; Forest Lake NTUA 1 had a dissolved-solids concentration of $398 \mathrm{mg} / \mathrm{L}$ and a chloride concentration of $50 \mathrm{mg} / \mathrm{L}$, and Rough Rock PM5 had a dissolved-solids concentration of $628 \mathrm{mg} / \mathrm{L}$ and a chloride concentration of $120 \mathrm{mg} / \mathrm{L}$. Concentrations of dissolved solids in water samples from the other 10 wells ranged from 102 to $352 \mathrm{mg} / \mathrm{L}$, and concentrations of chloride ranged from 1.3 to $7.1 \mathrm{mg} / \mathrm{L}$. The areal distribution of dissolved solids generally was similar to the distribution of water types. Lower concentrations of dissolved solids are in the recharge areas of the north and northwest, and higher concentrations of dissolved solids are in areas to the south and east (fig. 12).

Trends in water chemistry over time were evaluated in water samples from 10 wells with data since about the mid-1980s or early 1990s (table 13, fig. 13). A Kendall's tau statistical test was made to determine if there are significant trends in the waterchemistry data from 7 wells with 8 or more years of data (Forest Lake NTUA 1, Hotevilla PM1, Kayenta PM2, Kykotsmovi PM2, Peabody 4, Rocky Ridge PM3, and Rough Rock PM5). For the 3 wells with insufficient data for statistical tests (Peabody 9, Red Lake PM1, and Second Mesa PM2), there does not appear to be any trends in the concentrations of dissolved solids, chloride, and sulfate (table 13). There are no significant trends in concentrations of dissolved solids, chloride, and sulfate in water samples from 6 of the 7 statistically tested wells (p-values were greater than 0.05). The concentration of one tested constituent (dissolved solids) in samples from Rocky Ridge PM3 significantly increased from 1990 to 2001 (p-value $=0.036)$.

The chemistry of water samples from the Forest Lake NTUA 1 well has varied considerably between 1982 and 2001 (table 13, fig. 13). This variation may be from insufficient purging of this deep well $(2,674 \mathrm{ft})$ that has multiple well screens throughout an interval of about $800 \mathrm{ft}$ from the lowest to highest screen (table 5).

Analyzed constituents from the 12 well samples were compared to U.S. Environmental Protection Agency (USEPA) Primary and Secondary DrinkingWater Regulations (U.S. Environmental Protection Agency, 2002). Maximum Contaminant Levels (MCLs), which are the primary regulations, are legally enforceable standards that apply to public water systems. MCLs protect drinking-water quality by limiting the levels of specific contaminants that can adversely affect public health. Secondary Maximum Contaminant Levels (SMCLs) provide guidelines for the control of contaminants that may cause cosmetic effects (such as skin or tooth discoloration) or aesthetic effects (such as taste, odor, or color) in drinking water. The USEPA recommends SMCLs for public water systems; however, compliance with these SMCLs is not mandatory. 


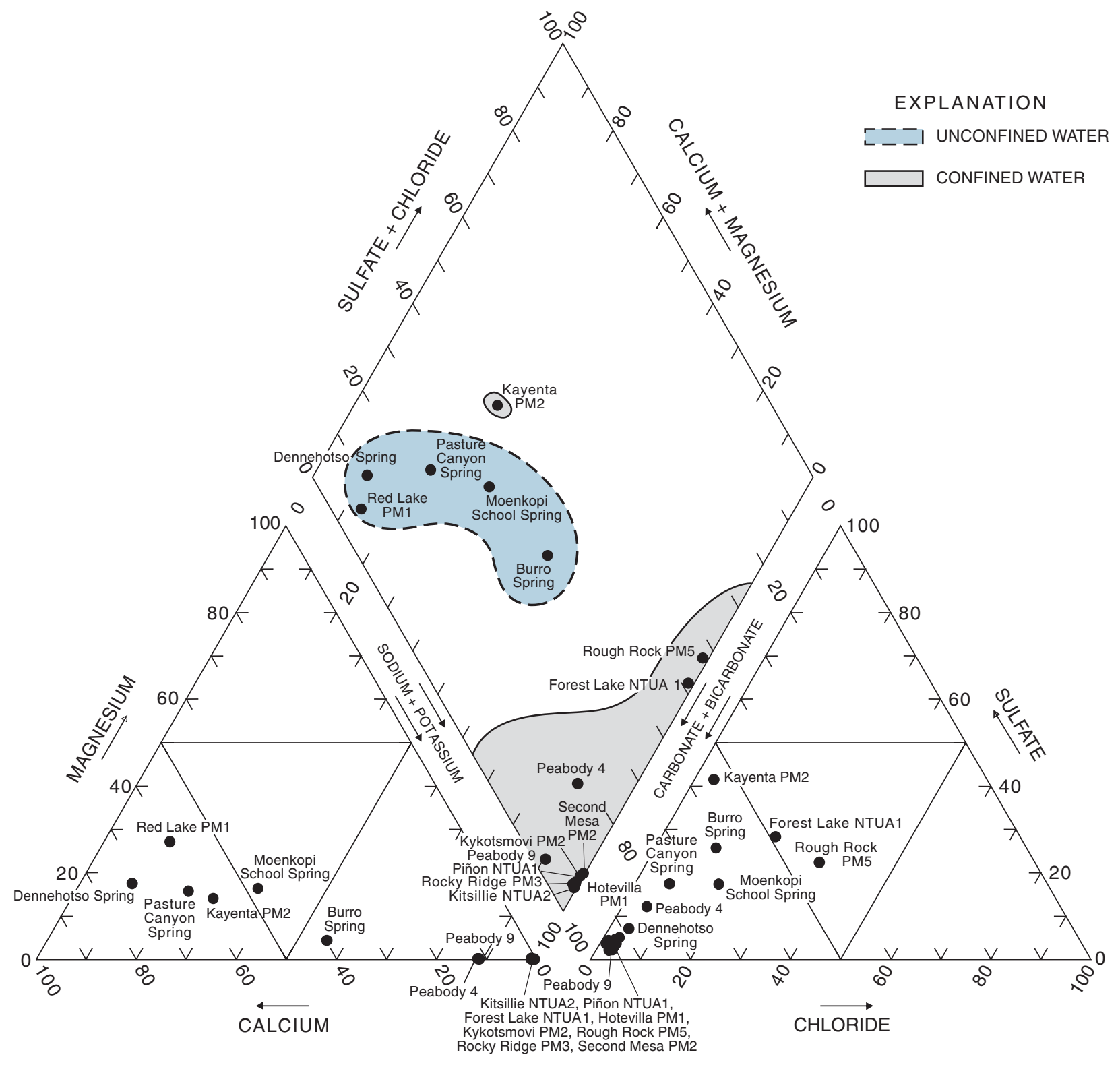

PERCENT OF TOTAL MILLIEQUIVALENTS PER LITER

Figure 11. Relative chemical compositions of ground water from the N aquifer, Black Mesa area, Arizona, 2001. 


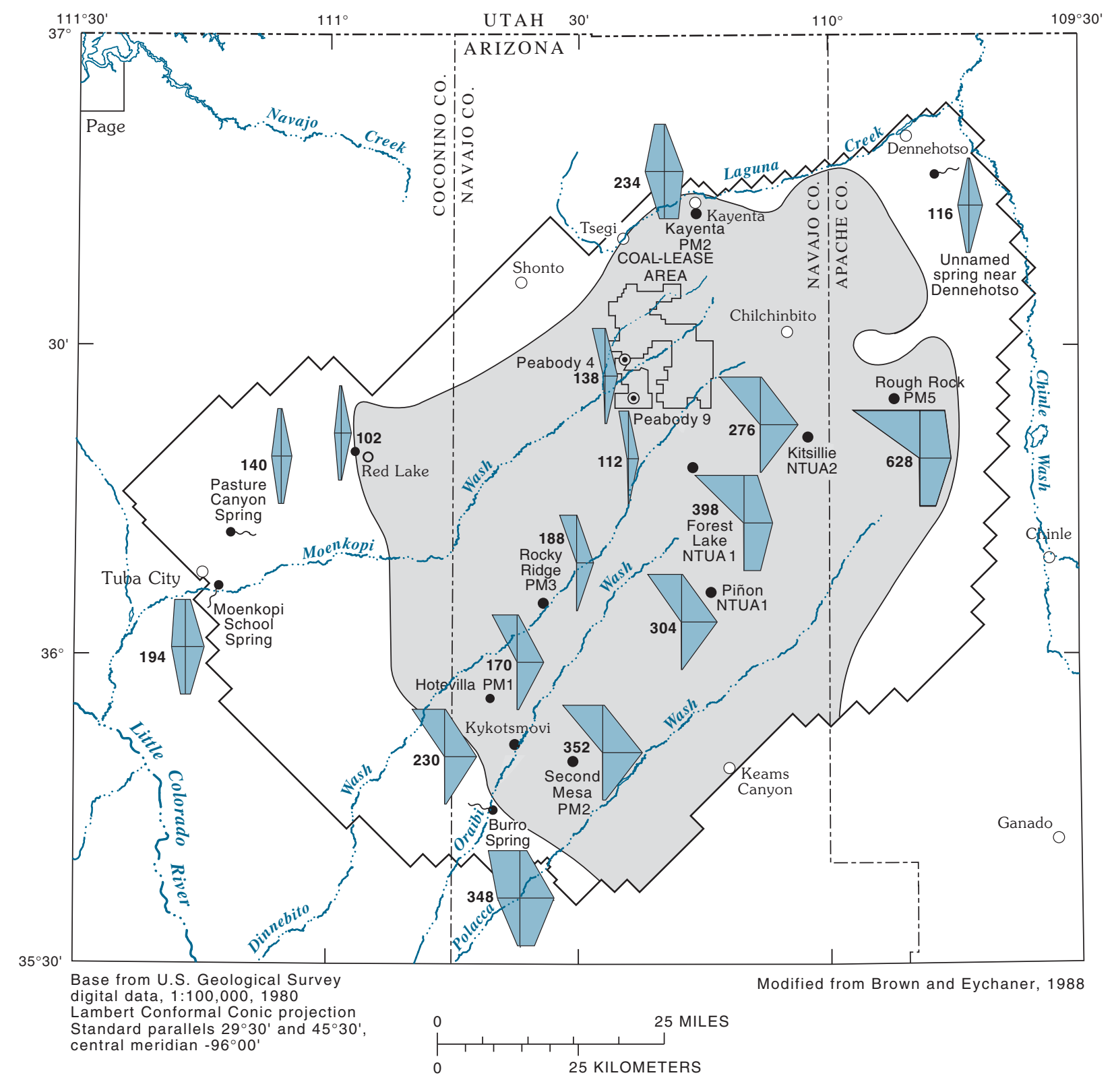

EXPLANATION

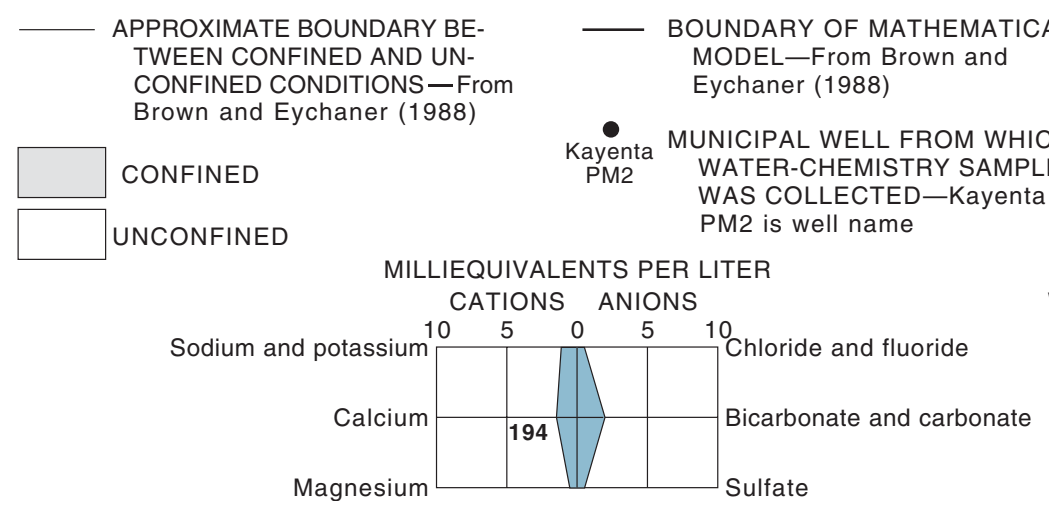
- INDUSTRIAL WELL FROM WHICH WATER-CHEMISTRY SAMPLE WAS COLLECTED

Pasture SPRING AT WHICH DISCHARGE Canyon WAS MEASURED AND WATERSpring CHEMISTRY SAMPLE WAS

WATER-CHEMISTRY DIAGRAM - Shows major chemical constituents in milliequivalents per liter. The diagrams are in a variety of shapes and sizes, and provide a means of comparing, correlating, and characterizing types of water. Number, 194, is dissolved-solids concentration, in milligrams per lite

Figure 12. Water chemistry and distribution of dissolved solids in the N aquifer, Black Mesa area, Arizona, 2001. 
Table 12. Physical properties and chemical analyses of water from selected industrial and municipal wells completed in the $\mathrm{N}$ aquifer, Black Mesa area, Arizona, 2001

$\left[{ }^{\circ} \mathrm{C}\right.$, degrees Celsius; $\mu \mathrm{S} / \mathrm{cm}$, microsiemens per centimeter at $25^{\circ} \mathrm{C} ; \mathrm{mg} / \mathrm{L}$, milligrams per liter; $\mu \mathrm{g} / \mathrm{L}$, micrograms per liter; $<$, less than. Dashes indicate no data]

\begin{tabular}{|c|c|c|c|c|c|}
\hline Common well name & $\begin{array}{l}\text { U.S. Geological Survey } \\
\text { identification number }\end{array}$ & Date of sample & $\begin{array}{c}\text { Temperature, } \\
\text { field }\left({ }^{\circ} \mathbf{C}\right)\end{array}$ & $\begin{array}{c}\text { Specific } \\
\text { conductance, } \\
\text { field }(\mu S / \mathrm{cm})\end{array}$ & pH, field (units) \\
\hline Forest Lake NTUA1 & 361737110180301 & 04-03-01 & 28.5 & 584 & 9.2 \\
\hline Hotevilla PM1 & 355518110400301 & 06-11-01 & 26.1 & 267 & 9.6 \\
\hline Kayenta PM2 & 364344110151201 & 03-13-01 & 15.7 & 331 & 7.9 \\
\hline Kitsillie NTUA 2 & 362043110030501 & 04-03-01 & 11.5 & 409 & 9.6 \\
\hline Kykotsmovi PM2 & 355215110375001 & 04-06-01 & 22.4 & 339 & 9.6 \\
\hline Peabody 4 & 362647110243501 & $03-15-01$ & 31.3 & 181 & 9.0 \\
\hline Peabody 9 & 362333110250001 & $03-15-01$ & 31.5 & 88 & 8.8 \\
\hline Piñon NTUA1 & 360527110122501 & 04-04-01 & 26.3 & 473 & 9.8 \\
\hline Red Lake PM1 & 361933110565001 & $03-12-01$ & 16.5 & 132 & 8.1 \\
\hline Rocky Ridge PM3 & 360422110353501 & 04-04-01 & 26.1 & 160 & 9.5 \\
\hline Rough Rock PM5 & 362418109514601 & $03-13-01$ & 21.1 & 980 & 8.8 \\
\hline Second Mesa PM2 & 354749110300101 & 06-11-01 & 20.4 & 597 & 9.6 \\
\hline Common well name & $\begin{array}{c}\text { Alkalinity, } \\
\text { field, dissolved } \\
\left(\mathrm{mg} / \mathrm{L} \text { as } \mathrm{CaCO}_{3}\right)\end{array}$ & $\begin{array}{c}\text { Nitrogen } \\
\mathrm{NO}_{2}+\mathrm{NO}_{3} \\
\text { dissolved } \\
\text { (mg/L as } \mathrm{N} \text { ) }\end{array}$ & $\begin{array}{c}\text { Phosphorus, } \\
\text { ortho, } \\
\text { dissolved } \\
\text { (mg/L as } \mathrm{P} \text { ) }\end{array}$ & $\begin{array}{c}\text { Calcium, } \\
\text { dissolved } \\
\text { (mg/L as Ca) }\end{array}$ & $\begin{array}{c}\text { Magnesium, } \\
\text { dissolved } \\
\text { (mg/L as } \mathrm{Mg})\end{array}$ \\
\hline Forest Lake NTUA1 & 147 & 0.43 & $<0.02$ & 1.1 & 0.10 \\
\hline Hotevilla PM1 & 137 & 1.0 & .02 & .65 & .01 \\
\hline Kayenta PM2 & 100 & .95 & $<.02$ & 41 & 6.1 \\
\hline Kitsillie NTUA 2 & 197 & 1.4 & $<.02$ & .55 & .02 \\
\hline Kykotsmovi PM2 & 171 & 1.2 & .03 & .49 & .01 \\
\hline Peabody 4 & 89 & .97 & $<.02$ & 4.6 & .03 \\
\hline Peabody 9 & 71 & .73 & $<.02$ & 3.6 & .03 \\
\hline Piñon NTUA 1 & 252 & 1.3 & $<.02$ & .49 & .01 \\
\hline Red Lake PM1 & 73 & 1.2 & $<.02$ & 18 & 5.0 \\
\hline Rocky Ridge PM3 & 118 & 1.3 & .02 & .40 & .01 \\
\hline Rough Rock PM5 & 218 & 1.0 & $<.02$ & 1.9 & .25 \\
\hline Second Mesa PM2 & 280 & $<.05$ & $<.02$ & .42 & .02 \\
\hline
\end{tabular}


Table 12. Physical properties and chemical analyses of water from selected industrial and municipal wells completed in the $\mathrm{N}$ aquifer, Black Mesa area, Arizona, 2001-Continued

\begin{tabular}{|c|c|c|c|c|c|}
\hline Common well name & $\begin{array}{l}\text { Sodium, dissolved } \\
\text { (mg/L as } \mathrm{Na})\end{array}$ & $\begin{array}{l}\text { Potassium, } \\
\text { dissolved } \\
\text { (mg/L as K) }\end{array}$ & $\begin{array}{c}\text { Chloride, } \\
\text { dissolved } \\
\text { (mg/L as Cl) }\end{array}$ & $\begin{array}{l}\text { Sulfate, dissolved } \\
\left(\mathrm{mg} / \mathrm{L} \text { as } \mathrm{SO}_{4}\right)\end{array}$ & $\begin{array}{l}\text { Fluoride, } \\
\text { dissolved } \\
\text { (mg/L as F) }\end{array}$ \\
\hline Forest Lake NTUA1 & 121 & 0.70 & 50 & 84 & 1.0 \\
\hline Hotevilla PM1 & 63 & .40 & 1.4 & 5.2 & ${ }^{1} .1$ \\
\hline Kayenta PM2 & 23 & 1.1 & 5.0 & 73 & .2 \\
\hline Kitsillie NTUA 2 & 99 & .50 & 5.0 & 4.5 & 1.6 \\
\hline Kykotsmovi PM2 & 79 & .40 & 3.5 & 8.2 & .2 \\
\hline Peabody 4 & 41 & .60 & 4.0 & 13 & .2 \\
\hline Peabody 9 & 30 & .50 & 1.8 & 2.7 & .2 \\
\hline Piñon NTUA 1 & 110 & .30 & 4.9 & 5.5 & .2 \\
\hline Red Lake PM1 & 4.6 & 1.9 & 1.8 & 2.2 & .2 \\
\hline Rocky Ridge PM3 & 55 & .40 & 1.3 & 5.4 & ${ }^{1} .1$ \\
\hline Rough Rock PM5 & 215 & 1.2 & 120 & 110 & 1.9 \\
\hline Second Mesa PM2 & 130 & .40 & 7.1 & 15 & .3 \\
\hline Common well name & $\begin{array}{l}\text { Silica, dissolved } \\
\left(\mathrm{mg} / \mathrm{L} \text { as } \mathrm{SiO}_{2}\right)\end{array}$ & $\begin{array}{c}\text { Arsenic, } \\
\text { dissolved } \\
\text { ( } \mu \mathrm{g} / \mathrm{L} \text { as As) }\end{array}$ & $\begin{array}{c}\text { Boron, } \\
\text { dissolved } \\
(\mu \mathrm{g} / \mathrm{L} \text { as } \mathrm{B})\end{array}$ & $\begin{array}{l}\text { Iron, dissolved } \\
(\mu \mathrm{g} / \mathrm{L} \text { as } \mathrm{Fe})\end{array}$ & $\begin{array}{c}\text { Dissolved solids, } \\
\text { residue at } 180^{\circ} \mathrm{C}, \\
\text { (mg/L) }\end{array}$ \\
\hline Forest Lake NTUA1 & 18 & 2.1 & 248 & 80 & 398 \\
\hline Hotevilla PM1 & 23 & 3.2 & 22 & $<10$ & 170 \\
\hline Kayenta PM2 & 15 & 1.5 & 24 & $<10$ & 234 \\
\hline Kitsillie NTUA 2 & 25 & 3.8 & 42 & 10 & 276 \\
\hline Kykotsmovi PM2 & 23 & 4.9 & 30 & $<10$ & 230 \\
\hline Peabody 4 & 21 & 2.7 & 23 & $<10$ & 138 \\
\hline Peabody 9 & 19 & 2.8 & 17 & $<10$ & 112 \\
\hline Piñon NTUA 1 & 26 & 4.2 & 61 & $<10$ & 304 \\
\hline Red Lake PM1 & 10 & .4 & 20 & $<10$ & 102 \\
\hline Rocky Ridge PM3 & 20 & 2.7 & 18 & $<10$ & 188 \\
\hline Rough Rock PM5 & 12 & 45 & 383 & ${ }^{1} 10$ & 628 \\
\hline Second Mesa PM2 & 21 & 17 & 93 & $<10$ & 352 \\
\hline
\end{tabular}

${ }^{1}$ Estimated value. 
Table 13. Specific conductance and concentrations of selected chemical constituents in water from industrial and municipal wells completed in the $\mathrm{N}$ aquifer, Black Mesa area, Arizona, 1968-2001

$\left[\mu \mathrm{S} / \mathrm{cm}\right.$, microsiemens per centimeter at 25 degrees Celsius; ${ }^{\circ} \mathrm{C}$, degrees Celsius; $\mathrm{mg} / \mathrm{L}$, milligrams per liter. Dashes indicate no data]

\begin{tabular}{|c|c|c|c|c|c|c|c|c|c|}
\hline Year & $\begin{array}{c}\text { Specific } \\
\text { conductance, } \\
\text { field }(\mu S / \mathrm{cm})\end{array}$ & $\begin{array}{l}\text { Dissolved } \\
\text { solids, } \\
\text { residue at } \\
180^{\circ} \mathrm{C} \\
\text { (mg/L) }\end{array}$ & $\begin{array}{l}\text { Chloride, } \\
\text { dissolved } \\
\text { (mg/L as Cl) }\end{array}$ & $\begin{array}{c}\text { Sulfate, } \\
\text { dissolved } \\
\text { (mg/L as } \\
\left.\mathrm{SO}_{4}\right)\end{array}$ & Year & $\begin{array}{c}\text { Specific } \\
\text { conductance, } \\
\text { field }(\mu S / \mathrm{cm})\end{array}$ & $\begin{array}{l}\text { Dissolved } \\
\text { solids, } \\
\text { residue at } \\
180^{\circ} \mathrm{C} \\
(\mathrm{mg} / \mathrm{L})\end{array}$ & $\begin{array}{l}\text { Chloride, } \\
\text { dissolved } \\
\text { (mg/L as Cl) }\end{array}$ & $\begin{array}{c}\text { Sulfate, } \\
\text { dissolved } \\
\text { (mg/L as } \\
\left.\mathrm{SO}_{4}\right)\end{array}$ \\
\hline \multicolumn{5}{|c|}{$\begin{array}{c}\text { Forest Lake NTUA } 1 \\
\end{array}$} & \multicolumn{5}{|c|}{ Kykotsmovi PM2 } \\
\hline 1982 & 470 & --- & 11 & 67 & 1988 & 368 & 212 & 3.2 & 8.6 \\
\hline 1990 & 375 & 226 & 8.2 & 38 & 1990 & 355 & 255 & 3.2 & 9.0 \\
\hline 1991 & ${ }^{1} 350$ & 183 & 10 & 24 & 1991 & $1_{374}$ & 203 & 4.4 & 7.9 \\
\hline 1993 & 693 & 352 & 35 & 88 & 1992 & 363 & 212 & 3.3 & 8.4 \\
\hline 1994 & 1734 & 430 & 56 & 100 & 1994 & ${ }^{1} 365$ & 212 & 3.6 & 8.5 \\
\hline 1995 & 470 & 274 & 13 & 60 & 1995 & 368 & 224 & 3.1 & 6.2 \\
\hline 1995 & 1,030 & 626 & 86 & 160 & 1996 & 365 & 224 & 3.3 & 8.5 \\
\hline 1995 & 488 & 316 & 16 & 71 & 1997 & $1_{379}$ & 222 & 3.0 & 8.0 \\
\hline 1996 & 684 & 368 & 44 & 79 & 1998 & 348 & 223 & 3.3 & 7.3 \\
\hline 1997 & ${ }^{1} 1,140$ & 714 & 78 & 250 & 1999 & 317 & 221 & 3.5 & 7.9 \\
\hline 1998 & 489 & 350 & 37 & 71 & 2001 & 339 & 230 & 3.5 & 8.2 \\
\hline 1999 & 380 & 259 & 16 & 49 & \multicolumn{5}{|c|}{ Peabody 4} \\
\hline 2001 & 584 & 398 & 50 & 84 & 1974 & 200 & 140 & 3.8 & 13 \\
\hline \multicolumn{5}{|c|}{ Hotevilla PM1 } & 1975 & 220 & 144 & 3.4 & 13 \\
\hline 1990 & 290 & 192 & 1.6 & 5 & 1976 & 240 & 138 & 2.9 & 19 \\
\hline 1991 & ${ }^{1} 304$ & 208 & .7 & 5.4 & 1979 & 220 & --- & 3.9 & 19 \\
\hline 1993 & 305 & 180 & 1.2 & 5.5 & 1980 & 230 & 139 & 4.3 & 13 \\
\hline 1994 & ${ }^{1} 307$ & 166 & 1.4 & 4.8 & 1986 & 205 & --- & 4.2 & 12 \\
\hline 1995 & 282 & 196 & 1.4 & 3.7 & 1987 & 194 & 135 & 35.0 & 13 \\
\hline 1996 & 328 & 186 & 1.3 & 5.3 & 1992 & 224 & 125 & 4.3 & 12 \\
\hline 1997 & ${ }^{1} 307$ & 185 & 1.5 & 5.2 & 1993 & 214 & 124 & 33.0 & 12 \\
\hline 2001 & 267 & 170 & 1.4 & 5.2 & 1996 & 214 & 140 & 3.8 & 12 \\
\hline \multicolumn{5}{|c|}{ Kayenta PM2 } & 1997 & ${ }^{1} 203$ & 139 & 3.5 & 12 \\
\hline 1982 & 360 & $\left(^{2}\right)$ & 4.5 & 58 & 1999 & 216 & 142 & 4.0 & 13 \\
\hline 1983 & 375 & $\left({ }^{2}\right)$ & 5.9 & 60 & 2001 & 181 & 138 & 4.0 & 13 \\
\hline 1984 & $1_{370}$ & 209 & 4.2 & 51 & \multicolumn{5}{|c|}{ Peabody 9} \\
\hline 1986 & 300 & 181 & 8.2 & 30 & 1986 & 181 & --- & 3.1 & 4.9 \\
\hline 1988 & 358 & 235 & 3.8 & 74 & 1987 & 148 & 102 & 2.8 & 4.1 \\
\hline 1992 & 383 & 210 & 5.6 & 78 & 1990 & 158 & 106 & 1.6 & 3.0 \\
\hline 1993 & 374 & 232 & 3.7 & 78 & 1991 & 155 & 83 & 2.7 & 3.1 \\
\hline 1994 & 1371 & 236 & 4.2 & 77 & 1993 & 157 & 94 & 1.6 & 2.9 \\
\hline 1995 & 371 & 250 & 4.2 & 72 & 1994 & --- & --- & 1.7 & --- \\
\hline 1996 & 370 & 238 & 3.8 & 76 & 1995 & 154 & 122 & 1.6 & 1.6 \\
\hline 1997 & 379 & 230 & 3.9 & 77 & 1998 & 109 & 109 & 1.7 & 2.5 \\
\hline 1998 & 349 & 236 & 3.7 & 71 & 2001 & 88 & 112 & 1.8 & 2.7 \\
\hline 1999 & 364 & 236 & 4.0 & 72 & \multicolumn{5}{|c|}{ Piñon NTUA 1} \\
\hline 2001 & 331 & 234 & 5.0 & 73 & \multirow{2}{*}{$\begin{array}{l}1998 \\
2001\end{array}$} & 460 & 304 & 4.6 & 4.7 \\
\hline \multicolumn{5}{|c|}{ Kitsillie NTUA 2} & & 473 & 304 & 4.9 & 5.5 \\
\hline 1997 & 1524 & 269 & 3.6 & 4.3 & \multicolumn{5}{|c|}{ Red Lake PM1 } \\
\hline 1998 & 379 & 270 & 3.8 & 4.1 & 1992 & 164 & 87 & 2.6 & 1.9 \\
\hline 1999 & 454 & 274 & 4.0 & 4.1 & 1993 & 156 & 84 & 1.6 & 2.1 \\
\hline 2001 & 409 & 276 & 5.0 & 4.5 & 1995 & 157 & 92 & 1.6 & 2.0 \\
\hline
\end{tabular}


Table 13. Specific conductance and concentrations of selected chemical constituents in water from industrial and municipal wells completed in the N aquifer, Black Mesa area, Arizona, 1968-2001—Continued

\begin{tabular}{|c|c|c|c|c|c|c|c|c|c|}
\hline Year & $\begin{array}{c}\text { Specific } \\
\text { conductance, } \\
\text { field }(\mu S / \mathrm{cm})\end{array}$ & $\begin{array}{l}\text { Dissolved } \\
\text { solids, } \\
\text { residue at } \\
180^{\circ} \mathrm{C} \\
\text { (mg/L) }\end{array}$ & $\begin{array}{c}\text { Chloride, } \\
\text { dissolved } \\
\text { (mg/L as Cl) }\end{array}$ & $\begin{array}{c}\text { Sulfate, } \\
\text { dissolved } \\
\text { (mg/L as } \\
\left.\mathrm{SO}_{4}\right)\end{array}$ & Year & $\begin{array}{c}\text { Specific } \\
\text { conductance, } \\
\text { field }(\mu S / \mathrm{cm})\end{array}$ & $\begin{array}{l}\text { Dissolved } \\
\text { solids, } \\
\text { residue at } \\
180^{\circ} \mathrm{C} \\
\text { (mg/L) }\end{array}$ & $\begin{array}{c}\text { Chloride, } \\
\text { dissolved } \\
\text { (mg/L as CI) }\end{array}$ & $\begin{array}{c}\text { Sulfate, } \\
\text { dissolved } \\
\text { (mg/L as } \\
\left.\mathrm{SO}_{4}\right)\end{array}$ \\
\hline \multicolumn{5}{|c|}{ Red Lake PM1—Continued } & \multicolumn{5}{|c|}{ Rough Rock PM5-Continued } \\
\hline 1997 & ${ }^{1} 156$ & 96 & 3.2 & 1.7 & 1988 & 1,120 & 624 & 130 & ${ }^{3} 110$ \\
\hline 1999 & 153 & 91 & 1.6 & 2.1 & 1991 & ${ }^{1} 1,210$ & 574 & 130 & 110 \\
\hline 2001 & 132 & 102 & 1.8 & 2.2 & 1993 & 1,040 & 614 & 130 & 110 \\
\hline \multicolumn{5}{|c|}{ Rocky Ridge PM3 } & 1994 & ${ }^{1} 1,070$ & 626 & 130 & 110 \\
\hline 1976 & 270 & --- & 5.3 & 3.8 & 1995 & 1,110 & 648 & 140 & 110 \\
\hline 1982 & 255 & --- & 1.4 & 6.0 & 1996 & 1,100 & 634 & 130 & 110 \\
\hline 1990 & 222 & 126 & 1.5 & 6.0 & 1997 & ${ }^{1} 1,060$ & 628 & 130 & 110 \\
\hline 1991 & 240 & 164 & .7 & 6.8 & 1998 & 894 & 637 & 130 & 110 \\
\hline 1993 & 254 & 146 & 1.3 & 5.5 & 1999 & 1,050 & 630 & 130 & 110 \\
\hline 1994 & 248 & 152 & 1.4 & 5.5 & 2001 & 980 & 628 & 120 & 110 \\
\hline 1995 & 242 & 166 & 1.3 & 4.0 & \multicolumn{5}{|c|}{ Second Mesa PM2 } \\
\hline 1996 & 256 & 156 & 2.0 & 5.8 & 1968 & 670 & --- & 14 & 35 \\
\hline 1997 & 238 & 159 & 2.5 & 5.0 & 1990 & 590 & 364 & 6.5 & 16 \\
\hline 1998 & 222 & 164 & 3.2 & 5.0 & 1991 & ${ }^{1} 595$ & 292 & 10 & 15 \\
\hline 2001 & 160 & 188 & 1.3 & 5.4 & 1993 & 630 & 350 & 7.5 & 15 \\
\hline \multicolumn{5}{|c|}{ Rough Rock PM5 } & 1994 & ${ }^{1} 605$ & 342 & 7.6 & 15 \\
\hline 1983 & 1,090 & $\left(^{2}\right)$ & 130 & 110 & 1995 & 610 & 357 & 7.2 & 14 \\
\hline 1984 & ${ }^{1} 1,100$ & 613 & 130 & 99 & 1997 & ${ }^{1} 646$ & 356 & 7.1 & 14 \\
\hline 1986 & 1,010 & 633 & 140 & 120 & 2001 & 597 & 352 & 7.1 & 15 \\
\hline
\end{tabular}

${ }^{1}$ Value is different in Black Mesa monitoring reports for 1999 and earlier years. The earlier reports showed values determined by laboratory analysis.

${ }^{2}$ Value is different in Black Mesa monitoring reports for 1999 and earlier years. The earlier reports showed values determined by the sum of constituents.

${ }^{3}$ Value is different in Black Mesa monitoring reports for 1999 and earlier years. The earlier reports applied a different rounding definition.

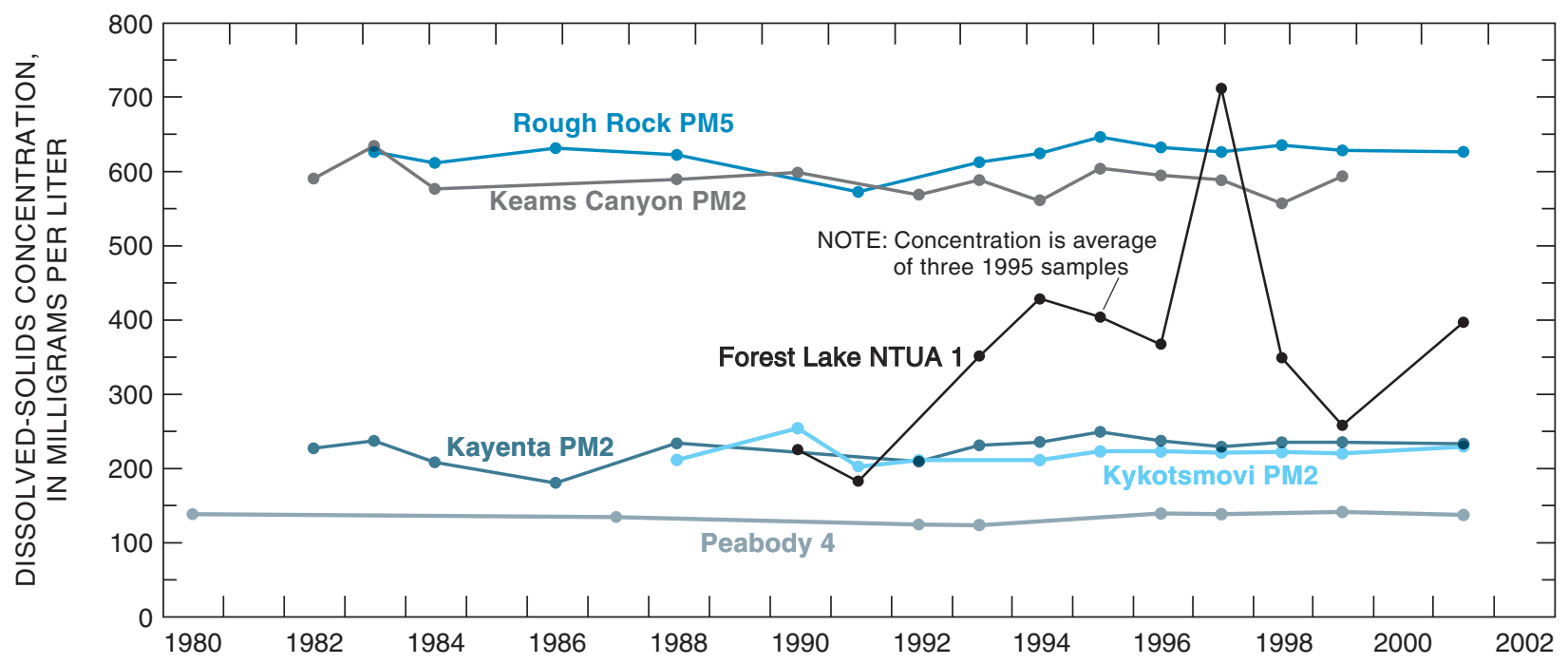

Figure 13. Dissolved-solids concentrations in water from wells Forest Lake NTUA 1, Kayenta PM2, Keams Canyon PM2, Kykotsmovi PM2, Rough Rock PM5, and Peabody 4, Black Mesa area, Arizona, 1980-2001. 
The concentrations of most of the analyzed constituents from the 12 well samples were below MCLs and SMCLs. The $\mathrm{pH}$ level, however, exceeded the upper SMCL (8.5 units) in samples from 10 of the 12 wells. One other SMCL was exceeded; the sample from Rough Rock PM5 had a dissolved-solids concentration of $628 \mathrm{mg} / \mathrm{L}$ (the SMCL is $500 \mathrm{mg} / \mathrm{L}$ ). Samples from two wells had arsenic concentrations that exceeded the MCL of $10 \mu \mathrm{g} / \mathrm{L}$. Arsenic concentrations were $45 \mu \mathrm{g} / \mathrm{L}$ in the sample from Rough Rock PM5 and $17 \mu \mathrm{g} / \mathrm{L}$ in the sample from Second Mesa PM2.

\section{Water from Springs that Discharge from the N Aquifer}

In 2001, water samples were collected from four springs in the unconfined part of the $\mathrm{N}$ aquifer (fig. 9). Water samples from three of the springs-Pasture Canyon Spring, Moenkopi School Spring, and the unnamed spring near Dennehotso-were a calcium bicarbonate type and had low dissolved-solids concentrations (116 to $194 \mathrm{mg} / \mathrm{L}$ ). The water sample from the fourth spring, Burro Spring, was a sodium bicarbonate type and had a much higher dissolvedsolids concentration of $348 \mathrm{mg} / \mathrm{L}$ (table 14, fig. 12). Concentrations of all the analyzed constituents in samples from the four springs were below current USEPA MCLs and SMCLs (U.S. Environmental Protection Agency, 2002).

From the late 1980s to 2001, there are no significant trends in the concentrations of dissolved solids, chloride, and sulfate in water samples from Burro Spring, the unnamed spring near Dennehotso, and Pasture Canyon Spring (table 15); p-values from a Kendall's tau statistical test were greater than 0.05 . From 1987 to 2001, concentrations of chloride and sulfate significantly increased in water samples from Moenkopi School Spring and concentrations of dissolved solids did not significantly change; the Kendall's tau p-values were 0.003 for chloride, 0.022 for sulfate, and 0.119 for dissolved solids.

\section{PERFORMANCE AND SENSITIVITY OF THE 1988 USGS NUMERICAL MODEL OF THE N AQUIFER}

\section{Introduction}

In the early 1980s, the U.S. Geological Survey developed a two-dimensional numerical model of the $\mathrm{N}$ aquifer in the Black Mesa area (Eychaner, 1983). A few years later, the model was updated and recalibrated by converting it to a new computer program and a finer spatial grid, and by revising estimates of selected aquifer properties (Brown and Eychaner, 1988). The 1988 model has been used to estimate the effects of industrial and municipal withdrawals on the $\mathrm{N}$ aquifer. Important effects include changes in water levels and changes in ground-water discharge to streams and springs.

This section describes results of an analysis of the performance and sensitivity of the 1988 USGS model of the $\mathrm{N}$ aquifer. The 1988 USGS model was constructed with data and information available in 1984. The performance analysis was done to determine how well the model has simulated 15 years of new water-level observation data (1985-99) and some additional and revised data before 1985. Numerical models of ground-water systems are constructed on the basis of available information and data, and if new data or information become available, testing the model's performance against that data will result in an increased understanding of the model and the groundwater system (Konikow and Bredehoeft, 1992). The sensitivity analysis was done to determine relations among the model parameters, observation data, and simulated values. Results of the performance and sensitivity analysis provide information that can be used to guide a data-collection plan and a study for updating and improving the model.

Objectives of this study were to (1) evaluate the performance of the model, (2) evaluate the sensitivity of the model, (3) determine potential revisions to improve the model on the basis of current data and information, and (4) determine potential new data and studies to improve the model. It was beyond the scope of the study to (1) recalibrate the model using trial-anderror or parameter-estimation techniques, (2) evaluate alternative conceptual models, or (3) evaluate the reliability and technical correctness of the model boundaries, hydraulic properties, and water budget.

Two previous studies evaluated the 1988 USGS model of the $\mathrm{N}$ aquifer. Papadopolus and Associates, Inc. (1993) evaluated the model by examining the quality of the input data and technical correctness of the model. Waterstone Environmental Hydrology and Engineering, Inc. (1995) used the parameter estimation model MODFLOWP (Hill, 1992) to evaluate the reliability and statistical uncertainty of the model parameters and input data through 1993. The limited scope of this study was to analyze model performance through 1999 and to determine sensitivity relations that provide information for updating and improving the model. 
Table 14. Physical properties and chemical analyses of water from selected springs that discharge from the $\mathrm{N}$ aquifer, Black Mesa area, Arizona, 2001

$\left[{ }^{\circ} \mathrm{C}\right.$, degree Celsius; $\mu \mathrm{S} / \mathrm{cm}$, microsiemens per centimeter at $25^{\circ} \mathrm{C} ; \mathrm{mg} / \mathrm{L}$, milligrams per liter; $\mu \mathrm{g} / \mathrm{L}$, micrograms per liter; $<$, less than. Dashes indicate no data]

\begin{tabular}{|c|c|c|c|c|c|c|}
\hline Spring name & $\begin{array}{l}\text { Bureau of } \\
\text { Indian Affairs } \\
\text { site number }\end{array}$ & $\begin{array}{c}\text { U.S. Geological } \\
\text { Survey identification } \\
\text { number }\end{array}$ & $\begin{array}{l}\text { Date of } \\
\text { sample }\end{array}$ & $\begin{array}{c}\text { Temperature } \\
\left({ }^{\circ} \mathrm{C}\right)\end{array}$ & $\begin{array}{c}\text { Specific } \\
\text { conductance, } \\
\text { field }(\mu S / \mathrm{cm})\end{array}$ & $\begin{array}{c}\text { pH } \\
\text { (field) } \\
\text { (units) }\end{array}$ \\
\hline Burro Spring & $6 \mathrm{M}-31$ & 354156110413701 & 04-02-01 & 22.0 & 480 & 8.5 \\
\hline Unnamed spring near Dennehotso & $8 \mathrm{~A}-224$ & 364656109425400 & 03-14-01 & 11.0 & 176 & 8.3 \\
\hline Moenkopi School Spring & $3 G S-77-6$ & 360632111131101 & $03-12-01$ & 16.6 & 313 & 7.5 \\
\hline Pasture Canyon Spring & $3 \mathrm{~A}-5$ & 361021111115901 & $06-12-01$ & 16.5 & 236 & 7.6 \\
\hline
\end{tabular}

\begin{tabular}{|c|c|c|c|c|c|c|}
\hline Spring name & $\begin{array}{l}\text { Alkalinity, } \\
\text { field, } \\
\text { dissolved } \\
\text { (mg/L as } \\
\left.\mathrm{CaCO}_{3}\right)\end{array}$ & $\begin{array}{c}\text { Nitrogen, } \\
\mathrm{NO}_{2}+\mathrm{NO}_{3}, \\
\text { dissolved } \\
\text { (mg/L as } \mathrm{N} \text { ) }\end{array}$ & $\begin{array}{c}\text { Phosphorus, } \\
\text { ortho, } \\
\text { dissolved } \\
\text { (mg/L as } \mathrm{P} \text { ) }\end{array}$ & $\begin{array}{l}\text { Hardness } \\
\text { (mg/L as } \\
\left.\mathrm{CaCO}_{3}\right)\end{array}$ & $\begin{array}{c}\text { Hardness, } \\
\text { non carbonate } \\
\text { (mg/L as } \\
\left.\mathrm{CaCO}_{3}\right)\end{array}$ & $\begin{array}{c}\text { Calcium, } \\
\text { dissolved } \\
\text { (mg/L as Ca) }\end{array}$ \\
\hline Burro Spring & 170 & 0.13 & $<0.02$ & 130 & --- & 46 \\
\hline Unnamed spring near Dennehotso & 78 & 1.5 & .02 & 78 & --- & 25 \\
\hline Moenkopi School Spring & 104 & 2.4 & $<.02$ & 99 & --- & 30 \\
\hline Pasture Canyon Spring & 75 & 4.4 & $<.02$ & 85 & --- & 27 \\
\hline
\end{tabular}

\begin{tabular}{|c|c|c|c|c|c|c|}
\hline Spring name & $\begin{array}{l}\text { Magnesium, } \\
\text { dissolved } \\
\text { (mg/L as } \mathrm{Mg} \text { ) }\end{array}$ & $\begin{array}{c}\text { Sodium, } \\
\text { dissolved } \\
\text { (mg/L as } \mathrm{Na})\end{array}$ & $\begin{array}{c}\text { Potassium, } \\
\text { dissolved } \\
\text { (mg/L as K) }\end{array}$ & $\begin{array}{l}\text { Chloride, } \\
\text { dissolved } \\
\text { (mg/L as Cl) }\end{array}$ & $\begin{array}{c}\text { Sulfate, } \\
\text { dissolved } \\
\left(\mathrm{mg} / \mathrm{L}^{2} \mathrm{SO}_{4}\right)\end{array}$ & $\begin{array}{l}\text { Fluoride, } \\
\text { dissolved } \\
\text { (mg/L as F) }\end{array}$ \\
\hline Burro Spring & 3.1 & 74 & 0.4 & 24 & 68 & 0.4 \\
\hline Unnamed spring near Dennehotso & 3.7 & 4.2 & 1.0 & 2.6 & 6.0 & .2 \\
\hline Moenkopi School Spring & 6.2 & 26 & 1.3 & 18 & 26 & .2 \\
\hline Pasture Canyon Spring & 4.2 & 11 & 1.2 & 5.1 & 17 & .2 \\
\hline Spring name & $\begin{array}{c}\text { Silica, } \\
\text { dissolved } \\
\left(\mathrm{mg} / \mathrm{L} \text { as } \mathrm{SiO}_{2}\right)\end{array}$ & $\begin{array}{c}\text { Arsenic, } \\
\text { dissolved } \\
(\mu \mathrm{g} / \mathrm{L} \text { as As })\end{array}$ & \multicolumn{2}{|c|}{$\begin{array}{c}\text { Boron, } \\
\text { dissolved } \\
(\mu \mathrm{g} / \mathrm{L} \text { as } \mathrm{B})\end{array}$} & $\begin{array}{l}\text { Iron, dissolved } \\
(\mu \mathrm{g} / \mathrm{L} \text { as } \mathrm{Fe})\end{array}$ & $\begin{array}{c}\text { Dissolved solids, } \\
\text { residue at } 180^{\circ} \mathrm{C} \\
(\mathrm{mg} / \mathrm{L})\end{array}$ \\
\hline Burro Spring & 13 & 0.7 & \multicolumn{2}{|c|}{75} & $<10$ & 348 \\
\hline Unnamed spring near Dennehotso & 12 & 2.5 & \multicolumn{2}{|c|}{18} & $<10$ & 116 \\
\hline Moenkopi School Spring & 13 & 2.5 & \multicolumn{2}{|c|}{44} & $<10$ & 194 \\
\hline Pasture Canyon Spring & 9.4 & 1.7 & \multicolumn{2}{|c|}{25} & $<10$ & 140 \\
\hline
\end{tabular}


Table 15. Specific conductance and concentrations of selected chemical constituents in water from selected springs that discharge from the $\mathrm{N}$ aquifer, Black Mesa area, Arizona, 1948-2001

$\left[\mu \mathrm{S} / \mathrm{cm}\right.$, microsiemens per centimeter at 25 degrees Celsius; $\mathrm{mg} / \mathrm{L}$, milligrams per liter; ${ }^{\circ} \mathrm{C}$, degrees Celsius. Dashes indicate no data]

\begin{tabular}{|c|c|c|c|c|}
\hline Year & $\begin{array}{l}\text { Specific conductance, } \\
\text { field }(\mu \mathrm{S} / \mathrm{cm})\end{array}$ & $\begin{array}{l}\text { Dissolved solids, } \\
\text { residue at } 180^{\circ} \mathrm{C} \\
\quad(\mathrm{mg} / \mathrm{L})\end{array}$ & $\begin{array}{c}\text { Chloride, dissolved } \\
\text { (mg/L as Cl) }\end{array}$ & $\begin{array}{l}\text { Sulfate, dissolved } \\
\left(\mathrm{mg} / \mathrm{L} \text { as } \mathrm{SO}_{4}\right)\end{array}$ \\
\hline \multicolumn{5}{|c|}{ Burro Spring } \\
\hline 1989 & 485 & 308 & 22 & 59 \\
\hline 1990 & ${ }^{1} 545$ & 347 & 23 & 65 \\
\hline 1993 & 595 & 368 & 30 & 85 \\
\hline 1994 & ${ }^{1} 597$ & 368 & 26 & 80 \\
\hline 1996 & 525 & 324 & 23 & 62 \\
\hline 1997 & ${ }^{1} 511$ & 332 & 26 & 75 \\
\hline 1998 & 504 & 346 & 25 & 70 \\
\hline 1999 & 545 & 346 & 25 & 69 \\
\hline 2001 & 480 & 348 & 24 & 68 \\
\hline \multicolumn{5}{|c|}{ Unnamed spring near Dennehotso } \\
\hline 1984 & 195 & 112 & 2.8 & 7.1 \\
\hline 1987 & 178 & ${ }^{2} 109$ & 3.4 & 7.5 \\
\hline 1992 & 178 & 108 & 3.6 & 7.3 \\
\hline 1993 & 184 & 100 & 3.2 & 8 \\
\hline 1995 & 184 & 124 & 2.6 & 5.7 \\
\hline 1996 & 189 & 112 & 2.8 & 8.2 \\
\hline 1997 & ${ }^{1} 170$ & 98 & 2.4 & 6.1 \\
\hline 1998 & 179 & 116 & 2.4 & 5.4 \\
\hline 1999 & 184 & 110 & 2.8 & 6.3 \\
\hline 2001 & 176 & 116 & 2.6 & 6.0 \\
\hline \multicolumn{5}{|c|}{ Moenkopi School Spring } \\
\hline 1952 & 222 & --- & 6 & --- \\
\hline 1987 & 270 & 161 & 12 & 19 \\
\hline 1988 & 270 & 155 & 12 & 19 \\
\hline 1991 & 297 & 157 & 14 & 20 \\
\hline 1993 & 313 & 204 & 17 & 27 \\
\hline 1994 & 305 & 182 & 17 & 23 \\
\hline 1995 & 314 & 206 & 18 & 22 \\
\hline 1996 & 332 & 196 & 19 & 26 \\
\hline 1997 & ${ }^{1} 305$ & 185 & 18 & 24 \\
\hline 1998 & 296 & 188 & 18 & 24 \\
\hline 1999 & 305 & 192 & 19 & 26 \\
\hline 2001 & 313 & 194 & 18 & 26 \\
\hline \multicolumn{5}{|c|}{ Pasture Canyon Spring } \\
\hline 1948 & $\mathrm{I}_{227}$ & $\left({ }^{2}\right)$ & 5 & 13 \\
\hline 1982 & 240 & --- & 5.1 & 18 \\
\hline 1986 & 257 & --- & 5.4 & 19 \\
\hline 1988 & 232 & 146 & 5.3 & 18 \\
\hline 1992 & 235 & 168 & 7.1 & 17 \\
\hline 1993 & 242 & 134 & 5.3 & 17 \\
\hline 1995 & 235 & 152 & 4.8 & 14 \\
\hline 1996 & 238 & 130 & 4.7 & 15 \\
\hline 1997 & 232 & 143 & 5.3 & 17 \\
\hline 1998 & 232 & 147 & 5.1 & 16 \\
\hline 1999 & 235 & 142 & 5.1 & 14 \\
\hline 2001 & 236 & 140 & 5.1 & 17 \\
\hline
\end{tabular}

${ }^{1}$ Value is different in Black Mesa monitoring reports for 1999 and earlier years. Earlier reports showed values from laboratory analysis.

${ }^{2}$ Value is different in Black Mesa monitoring reports for 1999 and earlier years. Earlier reports showed values determined by the sum of constituents. 
The two-dimensional 1988 USGS model was constructed using the MODFLOW program (McDonald and Harbaugh, 1984). The center of the model area is simulated as confined and the outside margins are simulated as unconfined (fig. 5). All lateral boundaries are no-flow boundaries, except for a narrow neck in the northeast, which is simulated as outflow. Recharge from precipitation is simulated as specified flux on $\mathrm{N}$-aquifer outcrop areas around the margins of the model (fig. 14). Downward leakage from the $\mathrm{D}$ aquifer is simulated with the general head boundary (fig. 14). Ground-water discharge is simulated with the river, drain, and evapotranspiration boundaries

(fig. 15). The lower boundary is assumed to be no-flow. The distributions of two of the most important hydraulic properties of the model-hydraulic conductivity and transmissivity - are shown in figures 16 and 17. Detailed information about the natural aquifer system and the model representation of the system were reported by Eychaner (1983) and Brown and Eychaner (1988).

\section{Approach}

The performance of the model was determined by evaluating the match between simulated and observed data for steady-state (before 1965) and transient (1965 to 1999) simulations. The 1988 USGS model included data through 1984, so withdrawal data from 1985 to 1999 were added to run the model from steady state to 1999. The amounts of annual ground-water withdrawals used in the model from 1965 to 1999 are shown in table 1 and figure 3 . No changes were made to the calibrated boundaries or parameter values of the 1988 model.

The 1988 model was calibrated using 123 steadystate heads, water-level changes in 6 continuous observation wells, and estimated ground-water discharge to 3 streams (table 16). This study analyzed the model using 126 steady-state heads, 331 water levels measured in 38 wells from 1965 to 1999, and estimated ground-water discharge to 3 streams and 1 group of springs (table 16 and fig. 18).

In addition to the new data from 1985 to 1999 , a few changes were made to the observation data used in the 1988 model. In 1994, a differential-globalpositioning-system (DGPS) survey determined new latitude, longitude, and land-surface altitude at 43 wells. The new DGPS data resulted in changes to the steady-state heads at those 43 wells and changes to the model cells for 12 wells. The maximum change in steady-state head was $25 \mathrm{ft}$; 95 percent of the changes were less than an absolute value of $15 \mathrm{ft}$, and 74 percent of the changes were less than an absolute value of $10 \mathrm{ft}$. There was no large areal bias in the changes in heads. Because of these changes in heads and cell locations, the statistics of steady-state model performance for this analysis are slightly different than the statistics for the 1988 model. The overall interpretation, however, was not changed.

New estimates of ground-water discharges also were made for this study. Discharge to Moenkopi Wash was estimated to be $3.1 \mathrm{ft}^{3} / \mathrm{s}$. The discharge was assumed to equal the average of the median winter streamflows during water years 1977-2000 at Moenkopi Wash at Moenkopi, Arizona (09401260; fig. 10c). Water years 1977-2000 are during a period of ground-water withdrawals in the Black Mesa area (fig. 3). The median winter flows calculated from the gaging-station record, however, are assumed to represent steady-state ground-water discharge because (1) there appears to be no appreciable water-level declines in the unconfined area of the $\mathrm{N}$ aquifer that discharges to Moenkopi Wash (fig. 5), (2) the Peabody Western Coal Company withdrawal wells are about 40 miles from the nearest point of ground-water discharge to Moenkopi Wash (fig. 4), and (3) there is no significant trend in the median winter flows from 1977 to 2000.

The 1988 model used a different value for discharge to Moenkopi Wash. Eychaner (1983, p. 10) estimated a base flow of $5.3 \mathrm{ft}^{3} / \mathrm{s}$ from streamflow records during water years 1926-41 at Moenkopi Wash near Tuba, Arizona. The new estimate of discharge to Moenkopi Wash was made because the streamflow data from the gaging station used in this study are more representative of $\mathrm{N}$-aquifer discharge than the data from the gaging station used by Eychaner (1983). The station used in this study is about 1.5 mile inside (east) of the model boundary (fig. 9), and the station used by Eychaner (1983) was about 5.5 miles outside (west) of the model boundary. Base flow at the gaging station used by Eychaner (1983) includes some discharge from ground water below the $\mathrm{N}$ aquifer and some discharge from springs in the Tuba City area. 


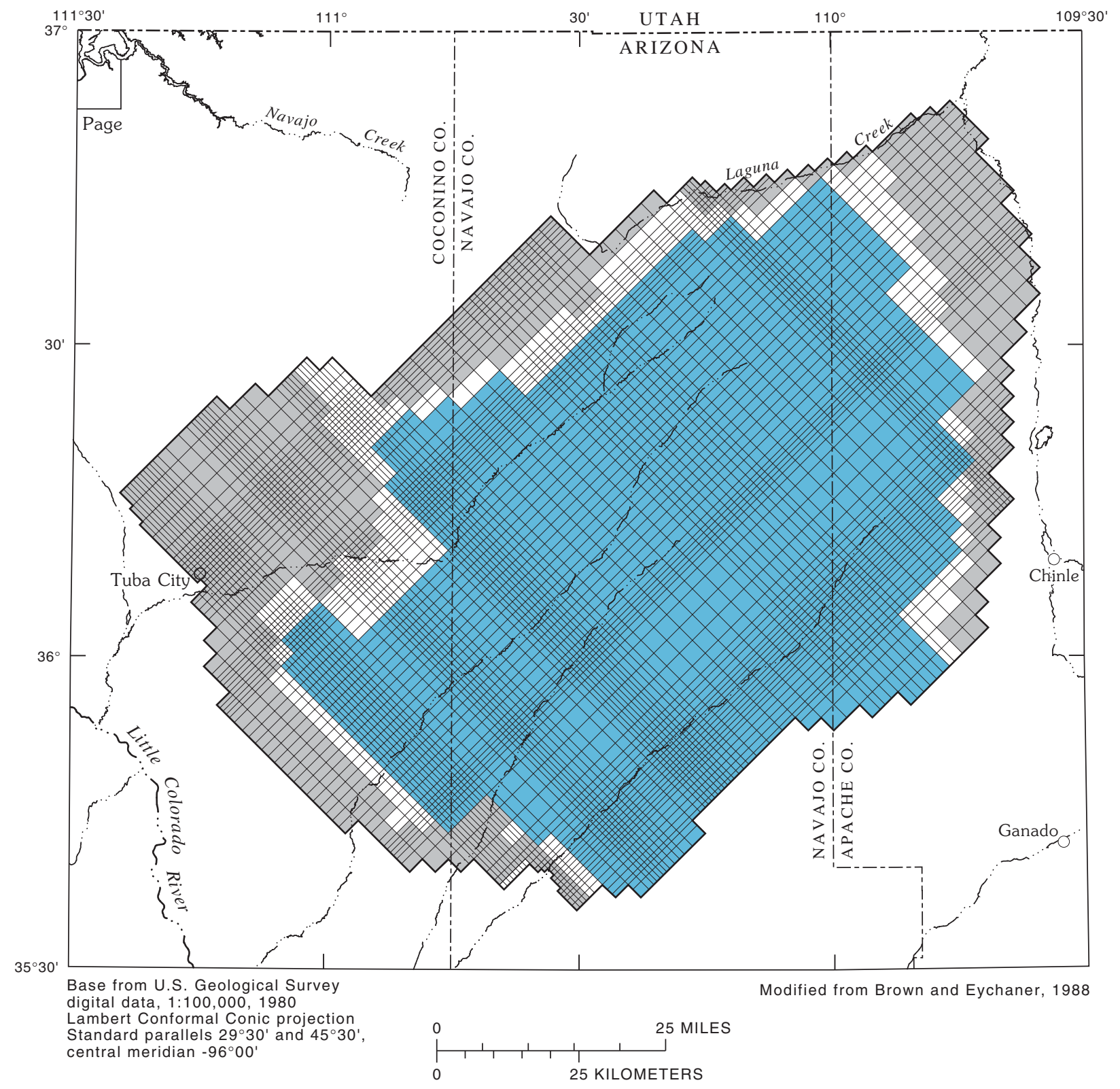

EXPLANATION

GENERAL-HEAD-BOUNDARY CELL-Simulates recharge by leakage from $D$ aquifer

RECHARGE CELL-Simulates recharge from infiltration and percolation of rainfall and snowmelt on outcrop areas of $\mathrm{N}$ aquifer

- MODEL BOUNDARY—No-flow conditions

Figure 14. Grid for 1988 USGS model of the N aquifer (Brown and Eychaner, 1988) and boundary conditions used to simulate groundwater recharge, Black Mesa area, Arizona. 


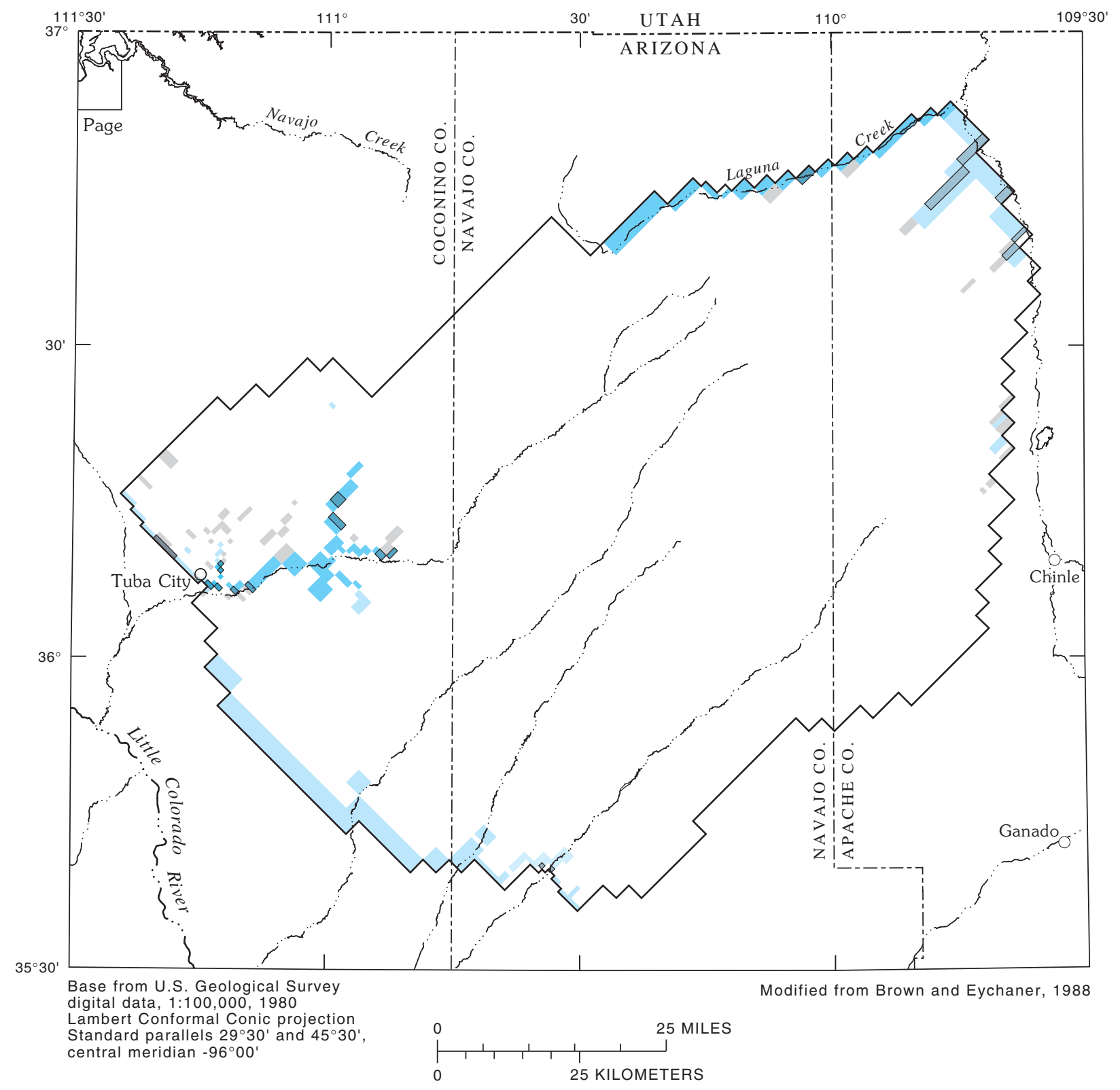

EXPLANATION

RIVER CELL-Simulates ground-water discharge to perennial streams or ground-water recharge from streams

DRAIN CELL-Simulates ground-water discharge to springs, alluvium in intermittent or ephemeral stream valleys, and seepage faces

EVAPOTRANSPIRATION CELL-Simulates evapotranspiration from the water table

Figure 15. Boundary of 1988 USGS model of the $\mathrm{N}$ aquifer (Brown and Eychaner, 1988) and boundary conditions used to simulate groundwater discharge, Black Mesa area, Arizona. 


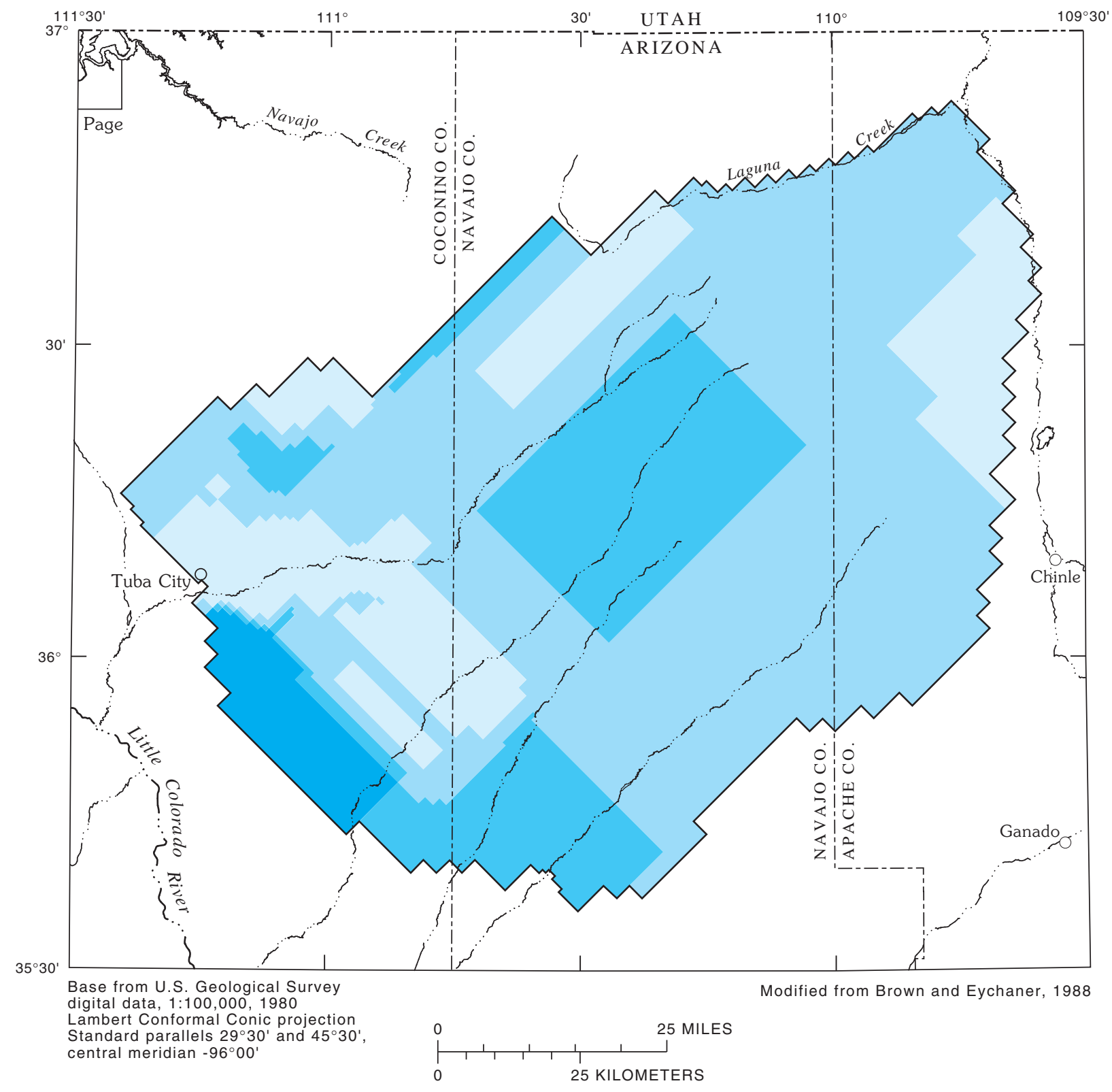

EXPLANATION

HYDRAULIC CONDUCTIVITY,

IN FEET PER DAY:

0.1 to $0.4 \quad 0.4$ to 0.8

0.8 to $1.2 \quad 1.2$ to 1.8

MODEL BOUNDARY

Figure 16. Distribution of hydraulic conductivity used in the 1988 USGS model of the N aquifer (Brown and Eychaner, 1988), Black Mesa area, Arizona. 


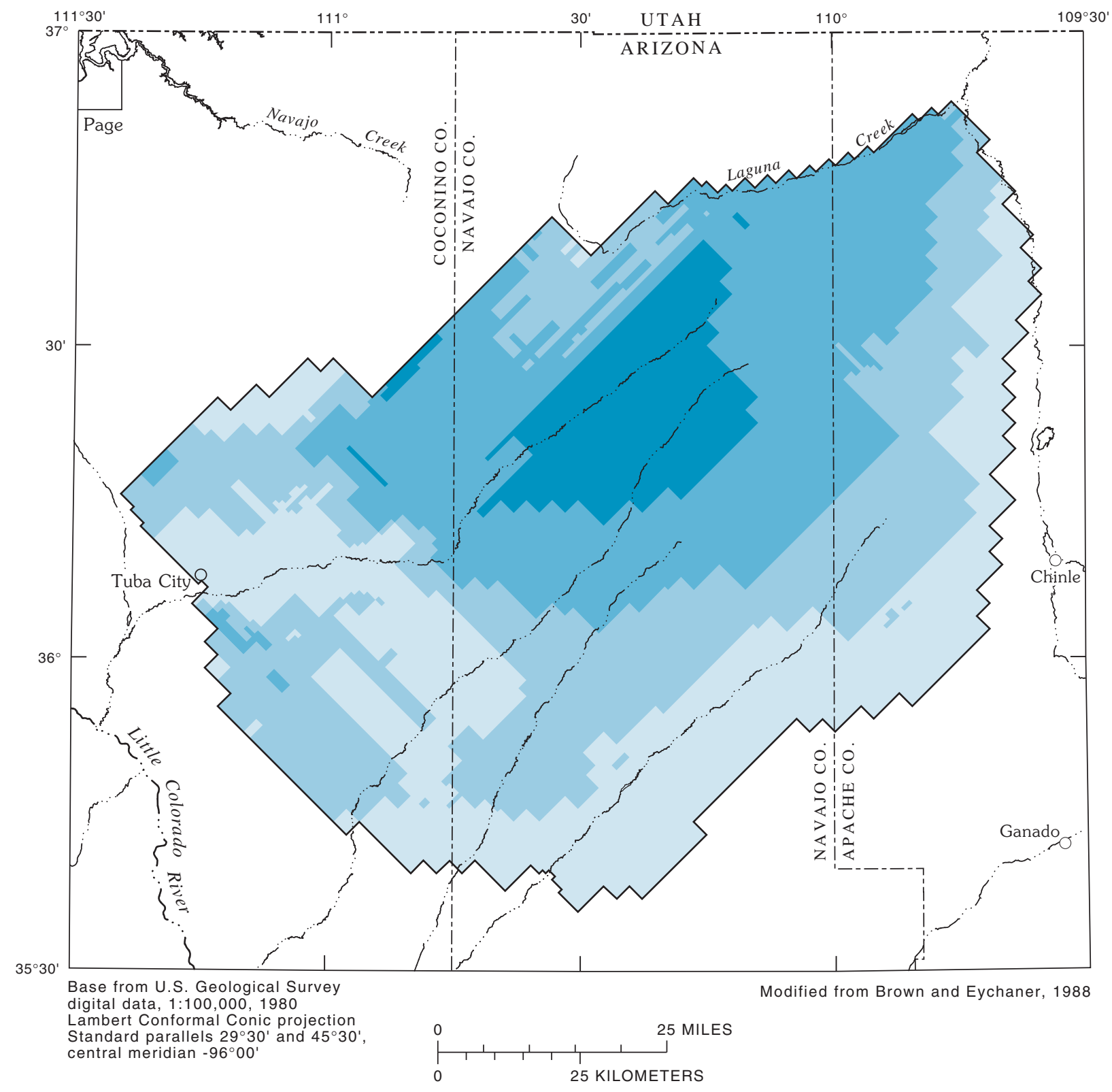

EXPLANATION

TRANSMISSIVITY, IN FEET

SQUARED PER DAY:

20 to $200 \quad 200$ to 400

400 to 700 - 700 to 1,040

MODEL BOUNDARY

Figure 17. Distribution of transmissivity used in the 1988 USGS model of the N aquifer (Brown and Eychaner, 1988), Black Mesa area, Arizona. 
Table 16. Observation data used in the 1988 USGS model of the $\mathrm{N}$ aquifer and in the analysis of the 1988 model for this report, Black Mesa area, Arizona

[1988 USGS model by Brown and Eychaner (1988)]

\begin{tabular}{|c|c|c|c|c|}
\hline \multirow[b]{2}{*}{ Type of observation } & \multicolumn{2}{|c|}{ Observations used in 1988 model } & \multicolumn{2}{|c|}{$\begin{array}{l}\text { Observations used in analysis of model for this } \\
\text { report }\end{array}$} \\
\hline & Number & $\begin{array}{l}\text { Time period } \\
\text { in model }\end{array}$ & Number & $\begin{array}{l}\text { Time period } \\
\text { in model }\end{array}$ \\
\hline Steady-state heads & 123 heads in 123 wells & ${ }^{1}$ Steady state & 126 heads in 126 wells & ${ }^{1}$ Steady state \\
\hline Flows (ground-water discharge) & $\begin{array}{l}\text { Flows in: } \\
\text { Laguna Creek and Chinle } \\
\text { Wash } \\
\text { Moenkopi Wash }\end{array}$ & $\begin{array}{c}\text { Steady state } \\
\text { and } \\
1965-84\end{array}$ & $\begin{array}{l}\text { Flows in: } \\
\text { Laguna Creek and Chinle } \\
\text { Wash } \\
\text { Moenkopi Wash } \\
\text { Moenkopi School Spring and } \\
\text { Pasture Canyon Spring }\end{array}$ & $\begin{array}{c}{ }^{3} \text { Steady state } \\
\text { and } \\
1965-99\end{array}$ \\
\hline Withdrawals & $\begin{array}{l}\text { Withdrawals from } 4 \text { wells in } \\
1965 \text { and } 57 \text { wells in } 1984\end{array}$ & $1965-84$ & $\begin{array}{l}\text { Withdrawals from } 4 \text { wells in } \\
1965 \text { and } 73 \text { wells in } 1999\end{array}$ & 1965-99 \\
\hline
\end{tabular}

\footnotetext{
${ }^{1}$ Steady state is before 1965 , actual period of observations is 1945 to 1972 . Observations during $1965-72$ are in areas not affected by withdrawals.

${ }^{2}$ Changes in heads at the six continuous observation wells were primarily used for evaluation of model performance, and an unknown number of other changes in heads were evaluated

${ }^{3}$ Actual period of data used for independent estimates (observations) of flows is variable, see pages 41 and 46 of text.
}

An initial estimate of a combined ground-water discharge to Laguna Creek and Chinle Wash was $4.0 \mathrm{ft}^{3} / \mathrm{s}$ (Eychaner, 1983, p. 10). Discharge to Chinle Wash was assumed to be 25 percent of the total flow $\left(1.0 \mathrm{ft}^{3} / \mathrm{s}\right)$ and this discharge was decreased by 20 percent $\left(0.2 \mathrm{ft}^{3} / \mathrm{s}\right)$ because there is some groundwater discharge to Chinle Wash from aquifers outside this study area. The final estimate for total discharge to Laguna Creek and Chinle Wash was, therefore, $3.8 \mathrm{ft}^{3} / \mathrm{s}$. Discharges to two springs near Tuba City were estimated from measured flows. A discharge of $210 \mathrm{gal} / \mathrm{m}\left(0.47 \mathrm{ft}^{3} / \mathrm{s}\right)$ to Pasture Canyon Spring was estimated from a measured flow in 1948 (S.C. Brown and L.C. Halpenny, U.S. Geological Survey, written commun., 1948). A discharge of $40 \mathrm{gal} / \mathrm{m}\left(0.09 \mathrm{ft}^{3} / \mathrm{s}\right)$ to Moenkopi School Spring was estimated from a measured flow in 1952 (table 6). For the analysis of model performance, discharges to Moenkopi School Spring and Pasture Canyon Spring were combined into one observation. The cells representing these springs are adjacent to each other (figs. 9 and 15).

Sensitivity of the 1988 USGS model was analyzed using techniques and indices available in the MODFLOWP inverse modeling program (Hill, 1992).
The model was run from steady state (before 1965) to 1999, and sensitivities and correlations were calculated for parameters and the new observation data set. The purpose of this sensitivity analysis was to evaluate the calibrated parameters and boundaries of the 1988 USGS model; so MODFLOWP was used with the parameter-estimation option and was forced to converge at the 1988 parameter values (Hill, 1992).

All the model boundaries and parameter values in the 1988 USGS model were used in the MODFLOWP application except for one change. The 1988 USGS model used the convertible-layer option for simulations in MODFLOW where cells can convert back and forth between unconfined and confined conditions (McDonald and Harbaugh, 1984). Part of the $\mathrm{N}$ aquifer in the Black Mesa area is confined and part is unconfined. The MODFLOWP program used in this analysis could not perform this process; it could only accommodate all confined or all unconfined simulations. For this analysis, therefore, transmissivity was used for the entire model area. The unconfined cells in the 1988 USGS model were assigned the unconfined storage coefficient and the confined cells were assigned the confined storage coefficient. 


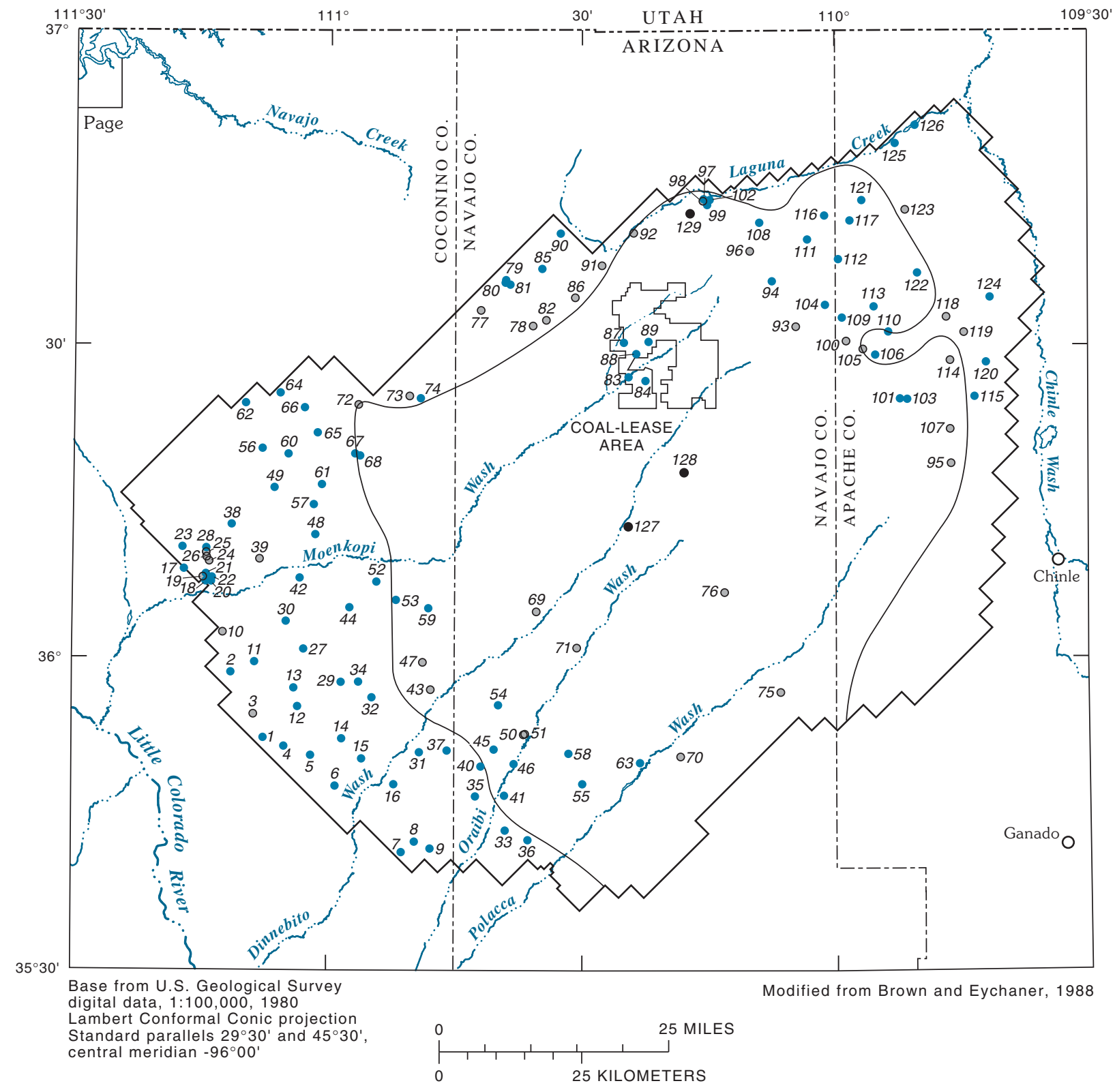

EXPLANATION

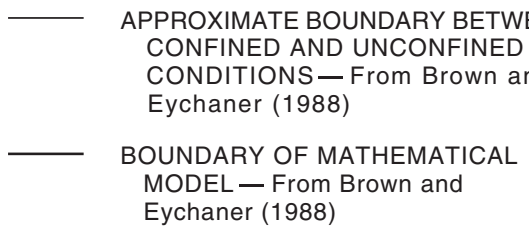

WELL AND INFORMATION COLLECTEDNumber accompanying symbol is well designation used in tables 18 and 20

- Steady-state head

- Steady-state head and transient-state change in head

- Transient-state change in head

Figure 18. Locations of observation wells used in the performance and sensitivity analysis of the 1988 USGS model of the $\mathrm{N}$ aquifer (Brown and Eychaner, 1988), Black Mesa area, Arizona. 
Transmissivity was calculated from the hydraulic conductivity and top and bottom altitudes of the $\mathrm{N}$ aquifer in confined areas, and from the hydraulic conductivity, water-table altitude, and bottom altitude of the $\mathrm{N}$ aquifer in unconfined areas.

To determine if the change made for MODFLOWP was reasonable for this analysis, the MODFLOWP model with transmissivity and the MODFLOW model with a convertible layer were run through 1999 and the results were compared. The simulated steady-state heads and budget components were within 0.1 percent, and simulated transient-state budget components were within 1 percent for all stress periods. Most of the simulated changes in heads in 1999 were within $1 \mathrm{ft}$ for both models. The only area with appreciable differences in head changes was the unconfined area near Tuba City. Several of the cells with pumped wells had negative head changes between 5 and $10 \mathrm{ft}$ greater in the MODFLOW convertible model than in the MODFLOWP transmissivity model. Some nearby cells also had head changes that were different by 1 to $5 \mathrm{ft}$ in the two models. These differences in simulated changes in heads had no effect on the results of the performance analysis in this report because the performance analysis used the MODFLOW convertible model.

The differences in the MODFLOW convertible model and MODFLOWP transmissivity model had a small effect on the sensitivity analysis. The magnitudes of sensitivities and parameter correlation coefficients are determined by the model boundaries, parameter values, and observations. The differences in the two models had no effect on the sensitivity analysis of steady-state conditions because the boundaries, parameter values, and observations are exactly the same in both models. There was a small effect on the sensitivity analysis of transient conditions because the MODFLOW convertible model used slightly smaller transmissivity values in the Tuba City area in the later years of the transient simulation. The parts of the magnitudes of sensitivities and parameter correlation coefficients that are determined by the observations used in the model would be no different between the MODFLOW convertible model and the MODFLOWP transmissivity model because the same observations are used in both models and the sensitivities and correlation coefficients are independent of model fit (Hill, 1998, p. 15 and 38).
MODFLOWP requires weights to be assigned to all observations. The weights are based on estimated measurement errors of the observations. Consequences of the weighting are that (1) relatively accurate measurements are weighted more heavily than relatively inaccurate measurements in a regression analysis, (2) different types of observations with different units can be summed and combined in a regression analysis, and (3) different types of observations can be combined into composite sensitivities that are used to evaluate the model. It was beyond the scope of this study to perform a regression analysis, but composite sensitivities were analyzed.

For this study, measurement errors were assigned to steady-state heads, transient changes in heads, and flows. Errors for heads were based on estimated errors in land-surface altitudes and estimated errors in the actual measurement of depth to water in a well. The measurement-error statistics were estimated using guidelines presented in Hill (1998, p. 45-49).

Information or assumptions used to estimate the errors were: (1) measurements of depths to water by the USGS were assumed to be accurate to within $0.2 \mathrm{ft}$, (2) measurements of depths to water reported from a driller were assumed to be accurate to within $1.2 \mathrm{ft}$, (3) all topographic maps were assumed to have a $20-\mathrm{ft}$ contour interval, (4) land-surface altitudes determined from DGPS data were assumed to be accurate to within $0.5 \mathrm{ft}$, and (5) a 90-percent confidence interval was used in equations presented in Hill (1998, p. 45-49).

Steady-state heads could have one of four errors. Heads measured by the USGS had (1) a standard deviation of $6.18 \mathrm{ft}$ for wells with land-surface altitudes determined from a map or (2) a standard deviation of $0.42 \mathrm{ft}$ for wells with altitudes determined from DGPS data. Heads reported from a driller had (3) a standard deviation of $6.79 \mathrm{ft}$ for wells with altitudes from a map or (4) a standard deviation of $1.03 \mathrm{ft}$ for wells with altitudes from DGPS data. Changes in heads from initial heads measured by the USGS had a standard deviation of $0.17 \mathrm{ft}$, and changes in heads from initial heads reported from a driller had a standard deviation of $0.74 \mathrm{ft}$.

The ground-water discharge estimated for Moenkopi Wash $\left(3.1 \mathrm{ft}^{3} / \mathrm{s}\right)$ was assigned a measurement error equal to the standard deviation of the median winter flows in the streamflow record. The standard deviation of $0.91 \mathrm{ft}^{3} / \mathrm{s}$ converts to a coefficient of variation (COV) of 29 percent. A similar method was used to estimate the measurement error of 
the $3.8 \mathrm{ft}^{3} / \mathrm{s}$ discharge to Laguna Creek and Chinle Wash. Median winter flows were calculated for the streamflow record during water years 1965-2000 at Chinle Creek near Mexican Water, Arizona (09379200). Station 09379200 is about 5 miles downstream of the confluence of Laguna Creek and Chinle Wash. The average of 27 median winter flows was $4.1 \mathrm{ft}^{3} / \mathrm{s}$ and the standard deviation was $1.51 \mathrm{ft}^{3} / \mathrm{s}$ (COV of 38 percent). Nine of the median winter flows were removed from the analysis because the median flows were obviously influenced by sustained winter runoff of rainfall or snowmelt. There was no trend in the median winter flows during 1965-2000. The COV of 38 percent was used for the measurement error for the $3.8 \mathrm{ft}^{3} / \mathrm{s}$ value resulting in a standard deviation of $1.44 \mathrm{ft}^{3} / \mathrm{s}$. There were no long-term measurement data for discharge to Pasture Canyon Spring and Moenkopi School Spring, so the estimated discharge of $0.56 \mathrm{ft}^{3} / \mathrm{s}$ was assigned a measurement error equal to a COV of 30 percent, which is between the measurement errors estimated for Moenkopi Wash and for Laguna Creek and Chinle Wash.

The sensitivity of the 1988 USGS model was analyzed using sensitivities and parameter correlation coefficients calculated by MODFLOWP. Sensitivities show the relations among model parameters, observation data, and simulated values. Correlation coefficients show the strength of association between pairs of parameters. Seven parameters were analyzed: (1) transmissivity, (2) recharge, (3) storage coefficient, (4) river-boundary conductance, (5) drain-boundary conductance, (6) general-head-boundary conductance, and (7) maximum evapotranspiration rate. Locations and distributions of these parameters are shown in figures 14-17. Information about how these parameters were estimated and defined is in Eychaner (1983) and Brown and Eychaner (1988). Three types of sensitivities were calculated for this analysis.

Dimensionless scaled sensitivities were calculated for observations, and they are made dimensionless by a weighting factor, which accounts for the measurement error of the observation. These sensitivities indicate the importance of different observations to the estimation of a single parameter or the importance of different parameters to the calculation of a simulated value (Hill, 1998).

Composite scaled sensitivities were calculated for each parameter using the dimensionless scaled sensitivities for observations, and they indicate the total amount of information provided by the observations for the estimation of each parameter. Composite scaled sensitivities reflect how well the parameters are defined by the available observations and indicate how well the parameters would be estimated by an inverse model. Generally, a parameter with a large composite scaled sensitivity can be estimated with a small confidence interval relative to a parameter with a smaller composite scaled sensitivity (Hill, 1998).

One-percent scaled sensitivities were calculated for the entire model grid and they are approximately equal to the amount that a simulated value would change if the parameter value increased by one percent. Onepercent scaled sensitivities have the same units as the simulated values. For this study, one-percent sensitivities were calculated for steady-state heads and for changes in head from steady state (before 1965) to 1999. A map of this sensitivity for a parameter can be used to compare the areal distribution of sensitivities for that parameter and to identify where additional observations would be most important to the estimation of that parameter (Hill, 1998).

Correlations between parameters are important because they are indicators of the uniqueness of a model. If a pair of parameters has a large correlation coefficient, the model is not unique and several models could be developed with different values for those parameters and still have similar fits to the observation data. The most common example of a pair of parameters with a large correlation coefficient is transmissivity and recharge.

Because the simulated values of a numerical ground-water model are nonlinear with respect to many estimated parameters, the results of this sensitivity analysis are only applicable to the model boundaries and parameter values of the 1988 USGS model and the observations used in this analysis. Using a different set of model boundaries, parameter values, or observations could provide different results, but the major characteristics of the results would likely be similar (Anderman and Hill, 1997, p. 28).

The last part of this study was to determine potential revisions to improve the model that could be done on the basis of current data and information, and to determine potential new data and studies that could improve the model. Results of the analysis of performance and sensitivity were compared with current data and information to accomplish these objectives. 


\section{Performance of Model}

The overall performance of the model for steadystate conditions is reasonable for residuals of heads (difference between observed and simulated heads); the mean residual is $5.3 \mathrm{ft}$, median residual is $-0.2 \mathrm{ft}$, root mean square error of residuals is $35 \mathrm{ft}$, and 80 percent of the absolute values of residuals are less than $38 \mathrm{ft}$ (tables 17 and 18). There is a small overall positive bias (fig. 19) and a small positive areal bias in the Shonto, west-central, and Tuba City areas (fig. 20). Positive bias is where simulated heads are consistently lower than observed heads. The Shonto area is the principal recharge area with the highest steady-state heads of the model area. The Tuba City area is the principal discharge area of the western part of the model area (fig. 20).

Simulated steady-state flows do not agree well with two of the three observed (estimated) flows (table 19). Simulated flow in Moenkopi Wash is 40 percent larger than the observed flow, and simulated flow for Moenkopi School Spring and Pasture Canyon Spring is 38 percent less than the observed flow. Simulated flow is within 2 percent of observed flow in Laguna Creek and Chinle Wash. This comparison between simulated and observed (estimated) flows, however, is only a rough approximation of performance because the accuracy of the observed flow values is uncertain.

The overall performance of the model for transient conditions is fair for residuals of changes in head (difference between observed and simulated changes in head); the mean residual for changes in head from steady state to 1999 is $4.3 \mathrm{ft}$, median residual is $3.6 \mathrm{ft}$, root mean square error of residuals is $40 \mathrm{ft}$, and 80 percent of the absolute values of residuals are less than $31 \mathrm{ft}$ (tables 17 and 20; figs. 7, 8, and 19). The model performance is biased in two areas. In the Tuba City area where the aquifer is unconfined, simulated changes in head are much more negative than observed changes in head (fig. 21); all six residuals are positive and three of the six residuals are between 75 and $155 \mathrm{ft}$. In the confined area of the aquifer (fig. 21), observed changes in head are more negative than simulated changes in head; 12 of the 17 residuals are negative and 8 of the residuals are between -57 and $-20 \mathrm{ft}$. The model performance could not be evaluated for changes in flows because there are no independent estimates or observations of changes in flows from 1965 to 1999.
Residuals for changes in head increase in magnitude as the time of simulation increases (fig. 22). This relation is not surprising because the model was calibrated with data only through 1984 . This relation also points out the need to periodically evaluate the performance of a ground-water model as new observation data become available.

\section{Sensitivity of Model}

The sensitivity of the model was evaluated using calculated sensitivities for parameters, observations, and simulated values, and correlations between parameters. Evaluated parameters were storage coefficient, transmissivity, recharge, maximum evapotranspiration rate, river-boundary conductance, drain-boundary conductance, and general-headboundary conductance. Evaluated observations and simulated values were steady-state heads, changes in heads, and flows (ground-water discharge).

The combined observations (steady-state heads, transient changes in heads, and flows) contain substantial information about storage coefficient, transmissivity, and recharge; moderate information about conductance for river, drain, and general-head boundaries; and little information about maximum evapotranspiration rate (fig. 23). Stated from another perspective, the combined observations are most sensitive to storage coefficient, transmissivity, and recharge, moderately sensitive to boundary conductances, and least sensitive to evapotranspiration.

Steady-state heads are most sensitive to transmissivity and recharge; moderately sensitive to conductance for river, drain, and general-head boundaries; and least sensitive to maximum evapotranspiration rate. Transient changes in heads are most sensitive to storage coefficient and transmissivity; moderately sensitive to recharge, river conductance, and general-head-boundary conductance; and least sensitive to drain conductance and maximum evapotranspiration rate.

The flow observations are less sensitive to parameters than the steady-state head and transient change-in-head observations. Composite scaled sensitivities for flow observations range from 0.01 to 1.9 and composite scaled sensitivities for heads and changes in heads range from 0.02 to 310 . Flow observations are most sensitive to transmissivity, recharge, river conductance, and drain conductance; moderately sensitive to storage coefficient; and least sensitive to maximum evapotranspiration rate and general-head-boundary conductance (fig. 23). 
Table 17. Summary of residuals for steady-state heads and changes in heads from steady state to 1999, Black Mesa area, Arizona [residual equals observed value minus simulated value]

\begin{tabular}{lccccc}
\hline \multicolumn{1}{c}{ Type of observation } & $\begin{array}{c}\text { Number of } \\
\text { observations }\end{array}$ & $\begin{array}{c}\text { Mean residual, } \\
\text { in feet }\end{array}$ & $\begin{array}{c}\text { Median residual, } \\
\text { in feet }\end{array}$ & $\begin{array}{c}\text { Root mean square error } \\
\text { of residuals, in feet }\end{array}$ & $\begin{array}{c}\text { 80th percentile of absolute } \\
\text { value of residuals, in feet }\end{array}$ \\
\hline Steady-state head & 126 & 5.3 & -0.2 & 34.9 & 38 \\
$\begin{array}{c}\text { Change in head from } \\
\text { steady state to 1999 }\end{array}$ & 33 & 4.3 & 3.6 & 39.7 & 31 \\
\hline
\end{tabular}

Table 18. Observed heads, simulated heads, and head residuals for steady-state simulation, Black Mesa area, Arizona [Map number from figure 18; head residual equals observed head minus simulated head]

\begin{tabular}{|c|c|c|c|c|c|}
\hline $\begin{array}{l}\text { Map } \\
\text { number }\end{array}$ & $\begin{array}{c}\text { USGS site } \\
\text { identification number }\end{array}$ & $\begin{array}{l}\text { Bureau of Indian Affairs site } \\
\text { number, or common name }\end{array}$ & $\begin{array}{c}\text { Observed head, } \\
\text { in feet above sea level }\end{array}$ & $\begin{array}{c}\text { Simulated head, } \\
\text { in feet above sea level }\end{array}$ & $\begin{array}{l}\text { Head residual, } \\
\text { in feet }\end{array}$ \\
\hline 1 & 355213111073601 & $3 \mathrm{~T}-504$ & 5,170 & 5,204 & -34 \\
\hline 2 & 355828111112701 & $3 \mathrm{~K}-326$ & 5,064 & 5,123 & -59 \\
\hline 3 & 355428111084601 & $3 \mathrm{~A}-28$ & 5,151 & 5,179 & -28 \\
\hline 4 & 355123111050901 & $3 \mathrm{~A}-151$ & 5,209 & 5,230 & -21 \\
\hline 5 & 355032111015901 & $3 \mathrm{~K}-328$ & 5,237 & 5,248 & -11 \\
\hline 6 & 3547341110590501 & $3 A-153$ & 5,240 & 5,281 & -41 \\
\hline 7 & 354116110511601 & $5 \mathrm{~T}-500$ & 5,280 & 5,286 & -6 \\
\hline 8 & 354218110494501 & $6 \mathrm{~K}-310 \mathrm{~N}$ & 5,316 & 5,311 & 5 \\
\hline 9 & 354137110475401 & $6 \mathrm{H}-79$ & 5,328 & 5,314 & 14 \\
\hline 10 & 360217111122601 & $3 \mathrm{~K}-325$ & 5,042 & 5,052 & -10 \\
\hline 11 & 355927111084101 & $3 \mathrm{~A}-27$ & 5,065 & 5,114 & -49 \\
\hline 12 & 355512111033301 & $3 \mathrm{~T}-540$ & 5,201 & 5,198 & 3 \\
\hline 13 & 355658111040201 & $3 A-149$ & 5,197 & 5,169 & 28 \\
\hline 14 & 355209110582301 & $3 \mathrm{M}-175$ & 5,241 & 5,256 & -15 \\
\hline 15 & 355013110560001 & $3 \mathrm{~K}-320$ & 5,256 & 5,279 & -23 \\
\hline 16 & 354746110521001 & $6 \mathrm{~K}-300$ & 5,297 & 5,301 & -4 \\
\hline 17 & 360819111170301 & Grey Hills 2 & 5,132 & 5,085 & 47 \\
\hline 18 & 360734111144801 & $3 \mathrm{~T}-333$ & 4,917 & 4,884 & 33 \\
\hline 19 & 360708111142901 & Kerley TP & 4,852 & 4,830 & 22 \\
\hline 20 & 360708111134901 & $3 G S-77-5$ & 4,785 & 4,763 & 22 \\
\hline 21 & 360751111142601 & $3 \mathrm{~T}-322-1$ & 4,938 & 4,902 & 36 \\
\hline 22 & 360731111134401 & $3 \mathrm{~T}-507$ & 4,872 & 4,855 & 17 \\
\hline 23 & 361025111171401 & 3T-545 & 5,257 & 5,271 & -14 \\
\hline 24 & 360904111140201 & 3T-508 (Tuba City NTUA1) & 5,090 & 5,005 & 85 \\
\hline 25 & 360953111142401 & 3T-546 (Tuba City NTUA4) & 5,172 & 5,131 & 41 \\
\hline 26 & 360924111142201 & Tuba City NTUA 3 & 5,142 & 5,083 & 59 \\
\hline 27 & 360042111025301 & $3 \mathrm{~K}-312$ & 5,095 & 5,122 & -27 \\
\hline
\end{tabular}


Table 18. Observed heads, simulated heads, and head residuals for steady-state simulation, Black Mesa area, Arizona—Continued

\begin{tabular}{|c|c|c|c|c|c|}
\hline $\begin{array}{l}\text { Map } \\
\text { number }\end{array}$ & $\begin{array}{c}\text { USGS site } \\
\text { identification number }\end{array}$ & $\begin{array}{l}\text { Bureau of Indian Affairs site } \\
\text { number, or common name }\end{array}$ & $\begin{array}{c}\text { Observed head, } \\
\text { in feet above sea level }\end{array}$ & $\begin{array}{c}\text { Simulated head, } \\
\text { in feet above sea level }\end{array}$ & $\begin{array}{l}\text { Head residual, } \\
\text { in feet }\end{array}$ \\
\hline 28 & 361018111142401 & Tuba City NTUA 5 & 5,205 & 5,184 & 21 \\
\hline 29 & 355733110582801 & $3 \mathrm{M}-176$ & 5,238 & 5,192 & 46 \\
\hline 30 & 360322111045801 & $3 \mathrm{~K}-329$ & 5,035 & 5,058 & -23 \\
\hline 31 & 355003110473801 & 6-3-ED3 & 5,331 & 5,325 & 6 \\
\hline 32 & 355615110551001 & $3 \mathrm{~K}-332$ & 5,274 & 5,253 & 21 \\
\hline 33 & 354322110390601 & $6-2 B 6$ & 5,346 & 5,364 & -18 \\
\hline 34 & 355734110562401 & $3 \mathrm{~T}-500 \mathrm{~A}$ & 5,245 & 5,226 & 19 \\
\hline 35 & 354637110423701 & $6-3-504$ & 5,344 & 5,370 & -26 \\
\hline 36 & 354227110362701 & $6 \mathrm{~K}-304$ & 5,345 & 5,357 & -12 \\
\hline 37 & 355102110455701 & $6 \mathrm{~K}-322$ & 5,351 & 5,355 & -4 \\
\hline 38 & 361237111112701 & $3 \mathrm{~T}-528$ & 5,234 & 5,240 & -6 \\
\hline 39 & 360918111080701 & Rare Metals 2 & 5,051 & 5,024 & 27 \\
\hline 40 & 354928110415701 & $6 \mathrm{~K}-310$ & 5,378 & 5,378 & 0 \\
\hline 41 & 354642110391201 & $6 \mathrm{~K}-2 \mathrm{C}-1$ & 5,361 & 5,384 & -23 \\
\hline 42 & 360729111032201 & $3 \mathrm{~T}-541$ & 4,939 & 4,951 & -12 \\
\hline 43 & 355648110475501 & $6 \mathrm{H}-55$ & 5,423 & 5,320 & 103 \\
\hline 44 & 360441110572801 & $3 \mathrm{~K}-330$ & 5,084 & 5,091 & -7 \\
\hline 45 & 355107110402601 & $6-3-\mathrm{S} 03$ & 5,395 & 5,401 & -6 \\
\hline 46 & 354944110380401 & $6 \mathrm{M}-52$ & 5,395 & 5,405 & -10 \\
\hline 47 & 355924110485001 & $3 \mathrm{~K}-311$ & 5,392 & 5,314 & 78 \\
\hline 48 & 361139111013401 & $3 \mathrm{~K}-323$ & 5,158 & 5,091 & 67 \\
\hline 49 & 361608111062501 & $3 \mathrm{~K}-324$ & 5,408 & 5,436 & -28 \\
\hline 50 & 355230110365801 & Kykotsmovi PM 1 & 5,437 & 5,430 & 7 \\
\hline 51 & 355236110364501 & Kykotsmovi PM 3 & 5,408 & 5,430 & -22 \\
\hline 52 & 360708110541901 & $3 \mathrm{~K}-345$ & 5,144 & 5,117 & 27 \\
\hline 53 & 360526110520001 & $3 \mathrm{M}-156$ & 5,285 & 5,228 & 57 \\
\hline 54 & 355518110400301 & Hotvilla PM 1 & 5,414 & 5,433 & -19 \\
\hline 55 & 354749110300101 & Second Mesa PM 2 & 5,401 & 5,428 & -27 \\
\hline 56 & 361954111075201 & $3 \mathrm{~K}-313$ & 5,540 & 5,532 & 8 \\
\hline 57 & 361432111014701 & 3T-518 & 5,347 & 5,337 & 10 \\
\hline 58 & 355041110313701 & Hopi Cultural Center & 5,429 & 5,443 & -14 \\
\hline 59 & 360437110481001 & $3 \mathrm{~K}-344$ & 5,409 & 5,363 & 46 \\
\hline 60 & 361922111044801 & $1 \mathrm{~T}-520$ & 5,545 & 5,529 & 16 \\
\hline 61 & 361627111005001 & $1 \mathrm{~K}-216$ & 5,418 & 5,407 & 11 \\
\hline 62 & 362414111095301 & $1 \mathrm{~K}-204$ & 5,646 & 5,638 & 8 \\
\hline 63 & 354950110231501 & Polacca PM 4 & 5,493 & 5,483 & 10 \\
\hline 64 & 362512111054801 & $1 \mathrm{~K}-222$ & 5,645 & 5,681 & -36 \\
\hline 65 & 362124111012001 & $1 \mathrm{~K}-226$ & 5,515 & 5,549 & -34 \\
\hline 66 & 362348111025401 & $1 \mathrm{~T}-522$ & 5,679 & 5,650 & 29 \\
\hline
\end{tabular}


Table 18. Observed heads, simulated heads, and head residuals for steady-state simulation, Black Mesa area, Arizona—Continued

\begin{tabular}{|c|c|c|c|c|c|}
\hline $\begin{array}{l}\text { Map } \\
\text { number }\end{array}$ & $\begin{array}{c}\text { USGS site } \\
\text { identification number }\end{array}$ & $\begin{array}{l}\text { Bureau of Indian Affairs site } \\
\text { number, or common name }\end{array}$ & $\begin{array}{c}\text { Observed head, } \\
\text { in feet above sea level }\end{array}$ & $\begin{array}{c}\text { Simulated head, } \\
\text { in feet above sea level }\end{array}$ & $\begin{array}{l}\text { Head residual, } \\
\text { in feet }\end{array}$ \\
\hline 67 & 361933110565001 & Red Lake PM 1 & 5,496 & 5,497 & -1 \\
\hline 68 & 361913110561901 & $1 \mathrm{~K}-228$ & 5,445 & 5,485 & -40 \\
\hline 69 & 360418110352701 & Rocky Ridge PM 2 & 5,553 & 5,537 & 16 \\
\hline 70 & 355023110182701 & Keams Canyon PM 2 & 5,517 & 5,515 & 2 \\
\hline 71 & 360055110304001 & BM Observation Well 5 & 5,545 & 5,541 & 4 \\
\hline 72 & 362406110563201 & $1 \mathrm{~K}-214$ & 5,583 & 5,588 & -5 \\
\hline 73 & 362456110503001 & $1 \mathrm{~K}-225$ & 5,662 & 5,671 & -9 \\
\hline 74 & 362443110491101 & 1P-511 & 5,670 & 5,666 & 4 \\
\hline 75 & 355638110064001 & Low Mountain PM 2 & 5,572 & 5,619 & -47 \\
\hline 76 & 360614110130801 & Piñon PM 6 & 5,653 & 5,625 & 28 \\
\hline 77 & 363309110420501 & $2 \mathrm{~K}-300$ & 6,088 & 6,092 & -4 \\
\hline 78 & 363143110355001 & BM Observation Well 4 & 6,129 & 6,081 & 48 \\
\hline 79 & 363604110390801 & Shonto PM 4 & 6,249 & 6,288 & -39 \\
\hline 80 & 363558110392501 & Shonto PM 2 & 6,256 & 6,284 & -28 \\
\hline 81 & 363538110383601 & $2 \mathrm{~T}-505$ & 6,232 & 6,276 & -44 \\
\hline 82 & 363213110342001 & $2 \mathrm{~K}-301$ & 6,151 & 6,119 & 32 \\
\hline 83 & 362647110243501 & Peabody 4 & 5,738 & 5,751 & -13 \\
\hline 84 & 362625110223701 & Peabody 3 & 5,726 & 5,728 & -2 \\
\hline 85 & 363709110345001 & $2 \mathrm{~K}-324$ & 6,520 & 6,446 & 74 \\
\hline 86 & 363423110305501 & $2 \mathrm{~T}-502$ & 6,264 & 6,120 & 144 \\
\hline 87 & 363005110250901 & Peabody 2 & 5,802 & 5,802 & 0 \\
\hline 88 & 362901110234101 & Peabody 5 & 5,771 & 5,763 & 8 \\
\hline 89 & 363007110221201 & Peabody 6 & 5,751 & 5,760 & -9 \\
\hline 90 & 364032110324101 & Betatakin Natl Monument & 6,695 & 6,587 & 108 \\
\hline 91 & 363727110274501 & $8 \mathrm{~T}-510$ & 6,163 & 6,105 & 58 \\
\hline 92 & 364034110240001 & $8 \mathrm{~T}-522$ & 5,915 & 5,940 & -25 \\
\hline 93 & 363137110044702 & Chilchinbito PM 3 & 5,545 & 5,537 & 8 \\
\hline 94 & 363558110073701 & 8T-419 & 5,522 & 5,513 & 9 \\
\hline 95 & 361832109462701 & $10 \mathrm{~T}-258$ & 5,602 & 5,601 & 1 \\
\hline 96 & 363850110100801 & BM Observation Well 2 & 5,531 & 5,517 & 14 \\
\hline 97 & 364350110154001 & $8 \mathrm{P}-450$ & 5,601 & 5,607 & -6 \\
\hline 98 & 364338110154601 & BM Observation Well 3 & 5,669 & 5,597 & 72 \\
\hline 99 & 364322110152001 & Kayenta USPH1 & 5,605 & 5,586 & 19 \\
\hline 100 & 363013109584901 & $8 K-443$ & 5,494 & 5,501 & -7 \\
\hline 101 & 362443109522801 & $10 \mathrm{~K}-221$ & 5,542 & 5,549 & -7 \\
\hline 102 & 364344110151201 & 8A-295 (Kayenta PM 2) & 5,582 & 5,586 & -4 \\
\hline 103 & 362438109513401 & Rough Rock PM 6 & 5,525 & 5,546 & -21 \\
\hline 104 & 363342110011901 & $8 \mathrm{~A}-121$ & 5,460 & 5,470 & -10 \\
\hline 105 & 362936109564101 & BM Observation Well 1 & 5,490 & 5,497 & -7 \\
\hline
\end{tabular}


Table 18. Observed heads, simulated heads, and head residuals for steady-state simulation, Black Mesa area, Arizona—Continued

\begin{tabular}{|c|c|c|c|c|c|}
\hline $\begin{array}{c}\text { Map } \\
\text { number }\end{array}$ & $\begin{array}{c}\text { USGS site } \\
\text { identification number }\end{array}$ & $\begin{array}{l}\text { Bureau of Indian Affairs site } \\
\text { number, or common name }\end{array}$ & $\begin{array}{c}\text { Observed head, } \\
\text { in feet above sea level }\end{array}$ & $\begin{array}{c}\text { Simulated head, } \\
\text { in feet above sea level }\end{array}$ & $\begin{array}{l}\text { Head residual, } \\
\text { in feet }\end{array}$ \\
\hline 106 & 362854109552201 & $8 \mathrm{~K}-435$ & 5,502 & 5,503 & -1 \\
\hline 107 & 362149109463301 & 10R-111 & 5,587 & 5,584 & 3 \\
\hline 108 & 364134110090501 & $8 A-138$ & 5,428 & 5,456 & -28 \\
\hline 109 & 363228109591901 & $8 \mathrm{~T}-528$ & 5,530 & 5,459 & 71 \\
\hline 110 & 363107109534901 & $8 \mathrm{~A}-273 \mathrm{~A}$ & 5,447 & 5,458 & -11 \\
\hline 111 & 363957110032401 & $8 \mathrm{~A}-136$ & 5,395 & 5,357 & 38 \\
\hline 112 & 363805109594501 & $8 \mathrm{~K}-1$ & 5,278 & 5,366 & -88 \\
\hline 113 & 363332109553301 & $8 \mathrm{~K}-430$ & 5,403 & 5,402 & 1 \\
\hline 114 & 362823109463101 & 10R-119 & 5,518 & 5,533 & -15 \\
\hline 115 & 362455109433801 & $10 \mathrm{~K}-235$ & 5,587 & 5,567 & 20 \\
\hline 116 & 364215110012201 & $8 \mathrm{~K}-420$ & 5,289 & 5,308 & -19 \\
\hline 117 & 364146109582201 & $8 \mathrm{~K}-421$ & 5,252 & 5,269 & -17 \\
\hline 118 & 363232109465601 & 9Y-92 & 5,446 & 5,444 & 2 \\
\hline 119 & 363103109445201 & 9Y-95 & 5,514 & 5,502 & 12 \\
\hline 120 & 362812109421601 & 10R-174 & 5,595 & 5,565 & 30 \\
\hline 121 & 364343109565701 & $8 \mathrm{~K}-431$ & 5,185 & 5,218 & -33 \\
\hline 122 & 363646109502201 & $8 \mathrm{~A}-179$ & 5,310 & 5,312 & -2 \\
\hline 123 & 364248109514601 & $8 \mathrm{~A}-180$ & 5,153 & 5,151 & 2 \\
\hline 124 & 363426109414601 & $9 \mathrm{~K}-215$ & 5,470 & 5,436 & 34 \\
\hline 125 & 364908109525301 & $8 \mathrm{~T}-505$ & 5,047 & 5,038 & 9 \\
\hline 126 & 365045109504001 & $8 \mathrm{~K}-521$ & 4,997 & 5,018 & -21 \\
\hline
\end{tabular}



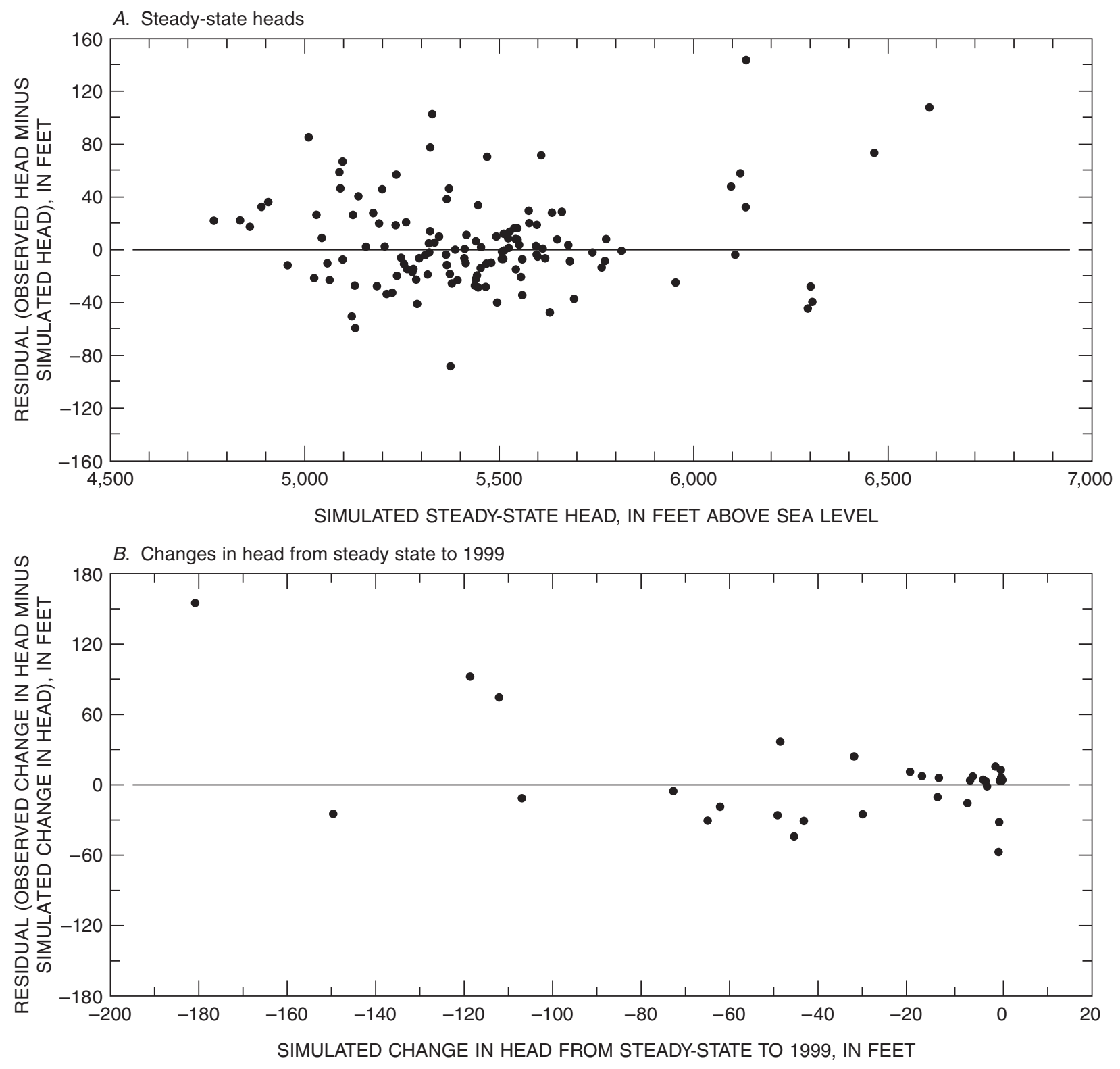

Figure 19. Relations between residuals and simulated values, Black Mesa area, Arizona. $A$, Steady-state heads. $B$, Changes in head from steady state to 1999. 


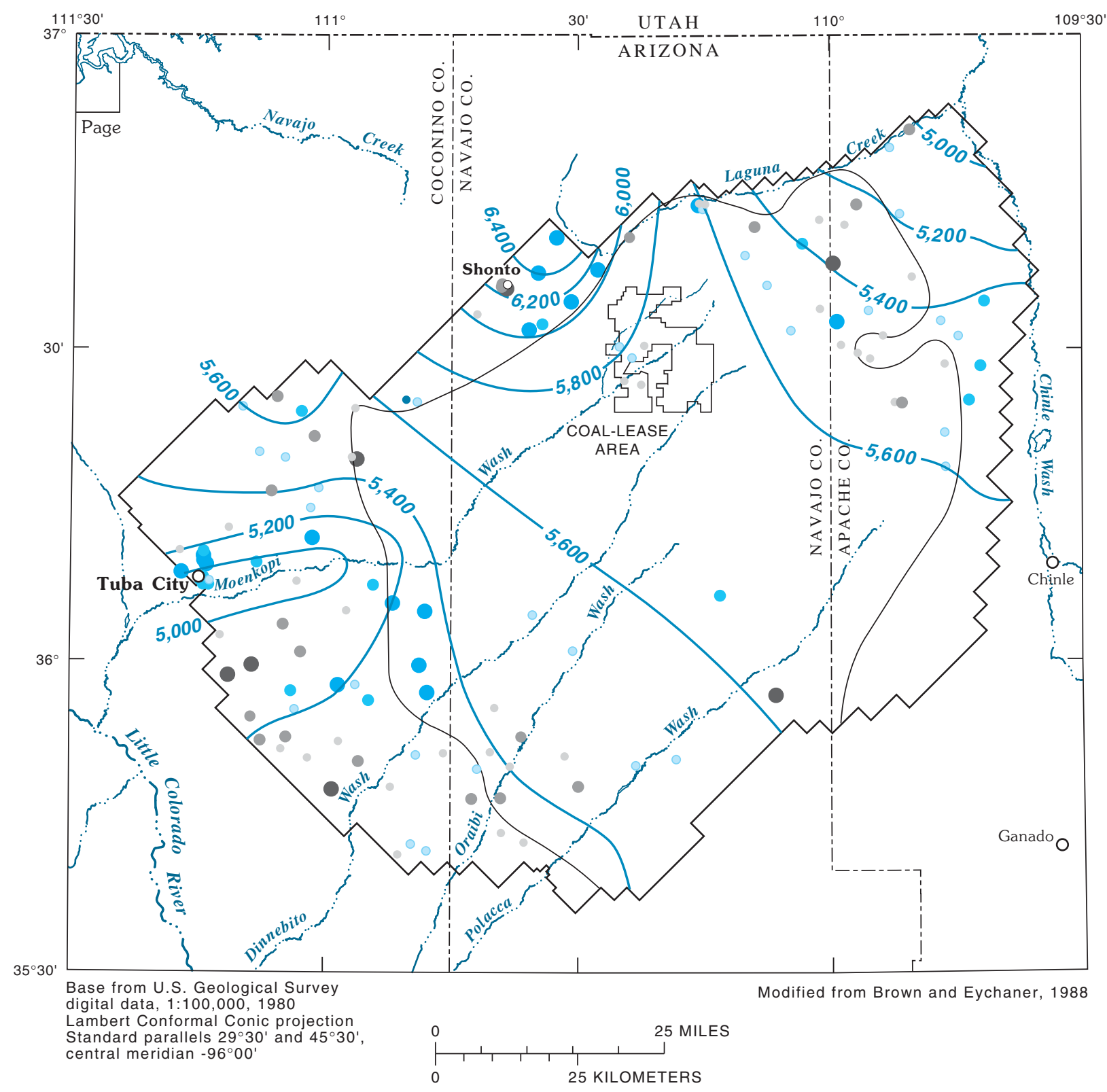

EXPLANATION

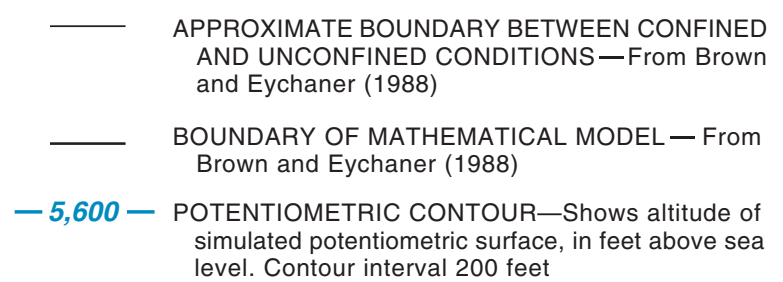

RESIDUALS FOR STEADY STATE HEADS, IN FEET POSITIVE: NEGATIVE:

- 0 to 20

- 20 to 40

- Greater than 40

-20 to -40

Less than -40

Figure 20. Residuals for steady-state heads and simulated steady-state potentiometric surface, Black Mesa area, Arizona. 
Table 19. Summary of residuals for observed (estimated) and simulated flows, Black Mesa area, Arizona

[Residual for steady-state flow equals observed flow minus simulated flow; $\mathrm{ft}^{3} / \mathrm{s}$, cubic feet per second]

\begin{tabular}{|c|c|c|c|c|c|}
\hline Stream or springs & $\begin{array}{l}\text { Observed (estimated) } \\
\text { steady-state flow, } \\
\text { in } \mathrm{ft}^{3} / \mathrm{s}\end{array}$ & $\begin{array}{c}\text { Simulated } \\
\text { steady-state flow, } \\
\text { in } \mathrm{ft}^{3} / \mathrm{s}\end{array}$ & $\begin{array}{c}\text { Residual for } \\
\text { steady-state flow, } \\
\text { in } \mathrm{ft}^{3} / \mathrm{s}\end{array}$ & $\begin{array}{l}\text { Weighted residual } \\
\text { for steady-state flow, } \\
\text { in } \mathrm{ft}^{3} / \mathrm{s}\end{array}$ & $\begin{array}{l}\text { Simulated change in flow } \\
\text { from steady state to } 1999, \\
\text { in } \mathrm{ft}^{3} / \mathrm{s}\end{array}$ \\
\hline Moenkopi Wash & 3.10 & 4.38 & -1.28 & -1.40 & -0.02 \\
\hline Laguna Creek and Chinle Wash & 3.80 & 3.87 & -0.07 & -.05 & -.59 \\
\hline $\begin{array}{l}\text { Moenkopi School Spring and } \\
\text { Pasture Canyon Spring }\end{array}$ & .56 & .21 & .35 & 1.98 & -.02 \\
\hline
\end{tabular}

Table 20. Observed and simulated changes in head from steady state to 1999, and residuals for changes in head, Black Mesa area, Arizona [Map number from figure 18; residual for change in head equals observed change in head minus simulated change in head]

\begin{tabular}{|c|c|c|c|c|c|}
\hline $\begin{array}{c}\text { Map } \\
\text { number }\end{array}$ & $\begin{array}{c}\text { USGS site } \\
\text { identification number }\end{array}$ & $\begin{array}{l}\text { Bureau of Indian Affairs site } \\
\text { number, or common name }\end{array}$ & $\begin{array}{l}\text { Observed change in head } \\
\text { from steady state to } 1999, \\
\text { in feet }\end{array}$ & $\begin{array}{l}\text { Simulated change in head } \\
\text { from steady state to 1999, } \\
\text { in feet }\end{array}$ & $\begin{array}{c}\text { Residual for } \\
\text { change in head, } \\
\text { in feet }\end{array}$ \\
\hline 10 & 360217111122601 & $3 \mathrm{~K}-325$ & 6.0 & -0.2 & 6.2 \\
\hline 18 & 360734111144801 & $3 \mathrm{~T}-333$ & -9.0 & -33.2 & 24.2 \\
\hline 24 & 360904111140201 & 3T-508 (Tuba City NTUA 1) & -38.2 & -112.9 & 74.7 \\
\hline 25 & 360953111142401 & 3T-546 (Tuba City NTUA 4) & -27.0 & -119.4 & 92.4 \\
\hline 26 & 360924111142201 & Tuba City NTUA 3 & -25.9 & -181.1 & 155.2 \\
\hline 39 & 360918111080701 & Rare Metals 2 & 4.4 & 0.0 & 4.4 \\
\hline 43 & 355648110475501 & $6 \mathrm{H}-55$ & -58.2 & -0.8 & -57.4 \\
\hline 50 & 355230110365801 & Kykotsmovi PM 1 & -12.9 & -49.8 & 36.9 \\
\hline 70 & 355023110182701 & Keams Canyon PM 2 & -174.8 & -150.1 & -24.7 \\
\hline 71 & 360055110304001 & BM Observation Well 5 & -79.2 & -73.8 & -5.4 \\
\hline 72 & 362406110563201 & $1 \mathrm{~K}-214$ & -32.6 & -0.7 & -31.9 \\
\hline 73 & 362456110503001 & $1 \mathrm{~K}-225$ & ${ }^{1} 14.2$ & ${ }^{1}-1.5$ & 15.7 \\
\hline 75 & 355638110064001 & Low Mountain PM 2 & -82.0 & -63.3 & -18.7 \\
\hline 76 & 360614110130801 & Piñon PM 6 & $1-119.2$ & $1-107.8$ & -11.4 \\
\hline 77 & 363309110420501 & $2 \mathrm{~K}-300$ & 4.2 & -0.1 & 4.3 \\
\hline 78 & 363143110355001 & BM Observation Well 4 & -0.6 & -3.7 & 3.1 \\
\hline 82 & 363213110342001 & $2 \mathrm{~K}-301$ & -4.7 & -3.4 & -1.3 \\
\hline 86 & 363423110305501 & $2 \mathrm{~T}-502$ & -9.6 & -20.7 & 11.1 \\
\hline 91 & 363727110274501 & $8 \mathrm{~T}-510$ & -23.5 & -7.8 & -15.7 \\
\hline 92 & 364034110240001 & $8 \mathrm{~T}-522$ & -3.5 & -7.2 & 3.7 \\
\hline 95 & 361832109462701 & $10 \mathrm{~T}-258$ & -8.3 & -14.2 & 5.9 \\
\hline 96 & 363850110100801 & BM Observation Well 2 & -76.4 & -50.4 & -26.0 \\
\hline 98 & 364338110154601 & BM Observation Well 3 & -90.8 & -46.7 & -44.1 \\
\hline 100 & 363013109584901 & $8 K-443$ & -10.6 & -18.0 & 7.4 \\
\hline 105 & 362936109564101 & BM Observation Well 1 & 0.0 & -4.3 & 4.3 \\
\hline 107 & 362149109463301 & 10R-111 & -25.0 & -14.5 & -10.5 \\
\hline 114 & 362823109463101 & 10R-119 & 0.6 & -6.6 & 7.2 \\
\hline 118 & 363232109465601 & $9 Y-92$ & 3.5 & -0.1 & 3.6 \\
\hline 119 & 363103109445201 & 9Y-95 & 12.5 & -0.3 & 12.8 \\
\hline 123 & 364248109514601 & $8 \mathrm{~A}-180$ & 3.0 & -0.5 & 3.5 \\
\hline 127 & 361225110240701 & BM Observation well 6 & $2-96.7$ & ${ }^{2}-66.1$ & -30.6 \\
\hline 128 & 361737110180301 & Forest Lake NTUA 1 & $3-75.3$ & $3-44.5$ & -30.8 \\
\hline 129 & 364226110171701 & $8 \mathrm{~T}-541$ & ${ }^{4}-56.4$ & $4-31.3$ & -25.1 \\
\hline
\end{tabular}

${ }^{1}$ Most recent heads are for 1998 instead of 1999.

${ }^{2}$ Changes in head are for 1977 to 1999.

${ }^{3}$ Changes in head are for 1982 to 1999 .

${ }^{4}$ Changes in head are for 1976 to 1999 . 


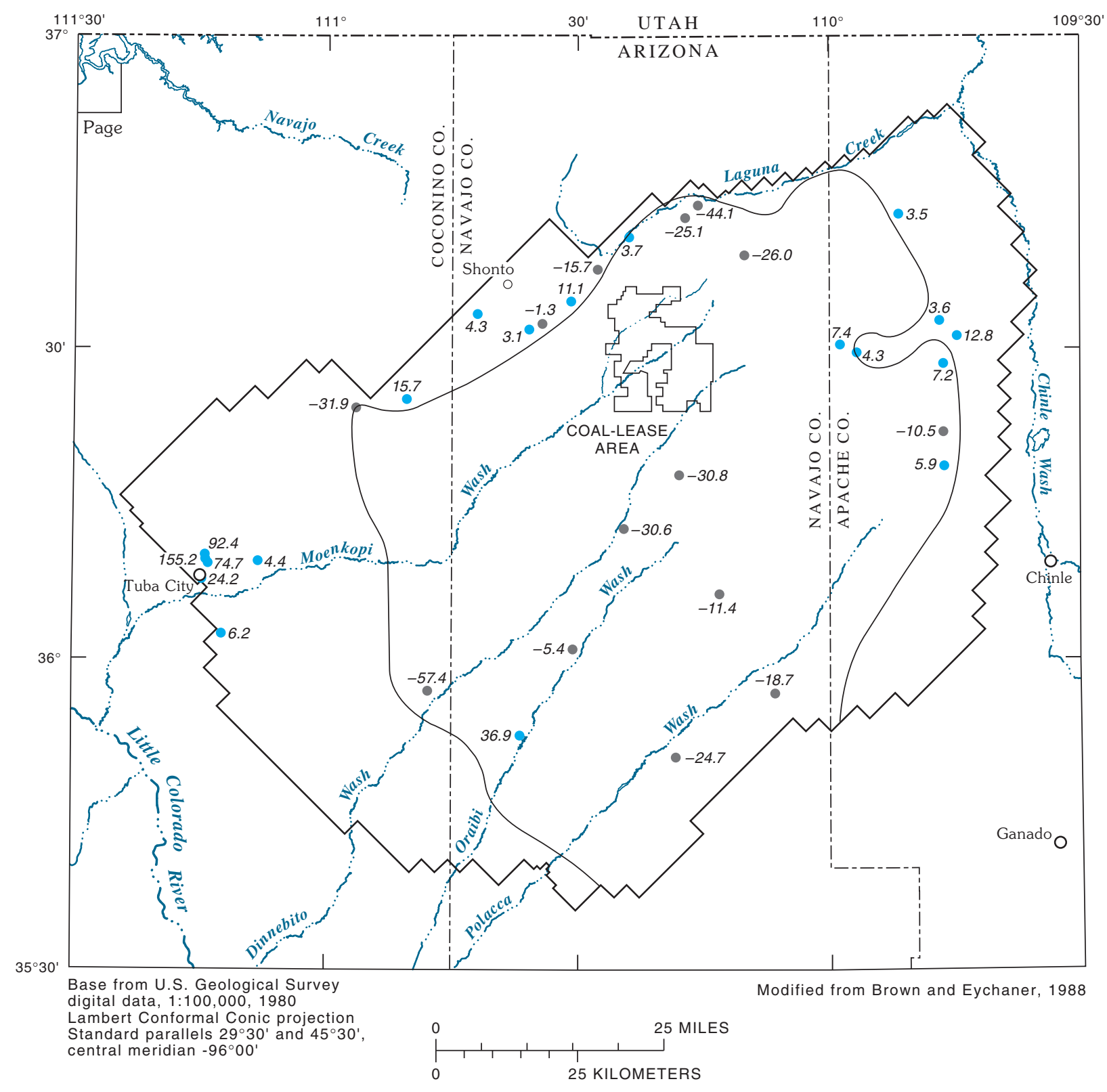

EXPLANATION

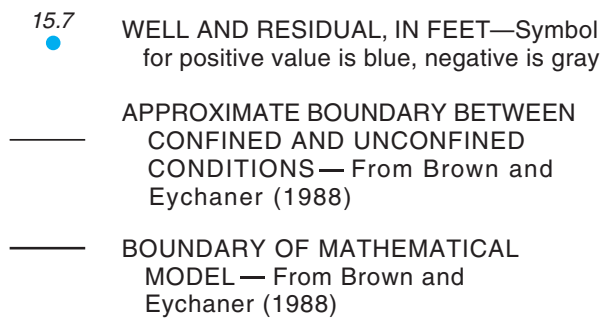

Figure 21. Residuals for changes in head from steady state to 1999, Black Mesa area, Arizona. 


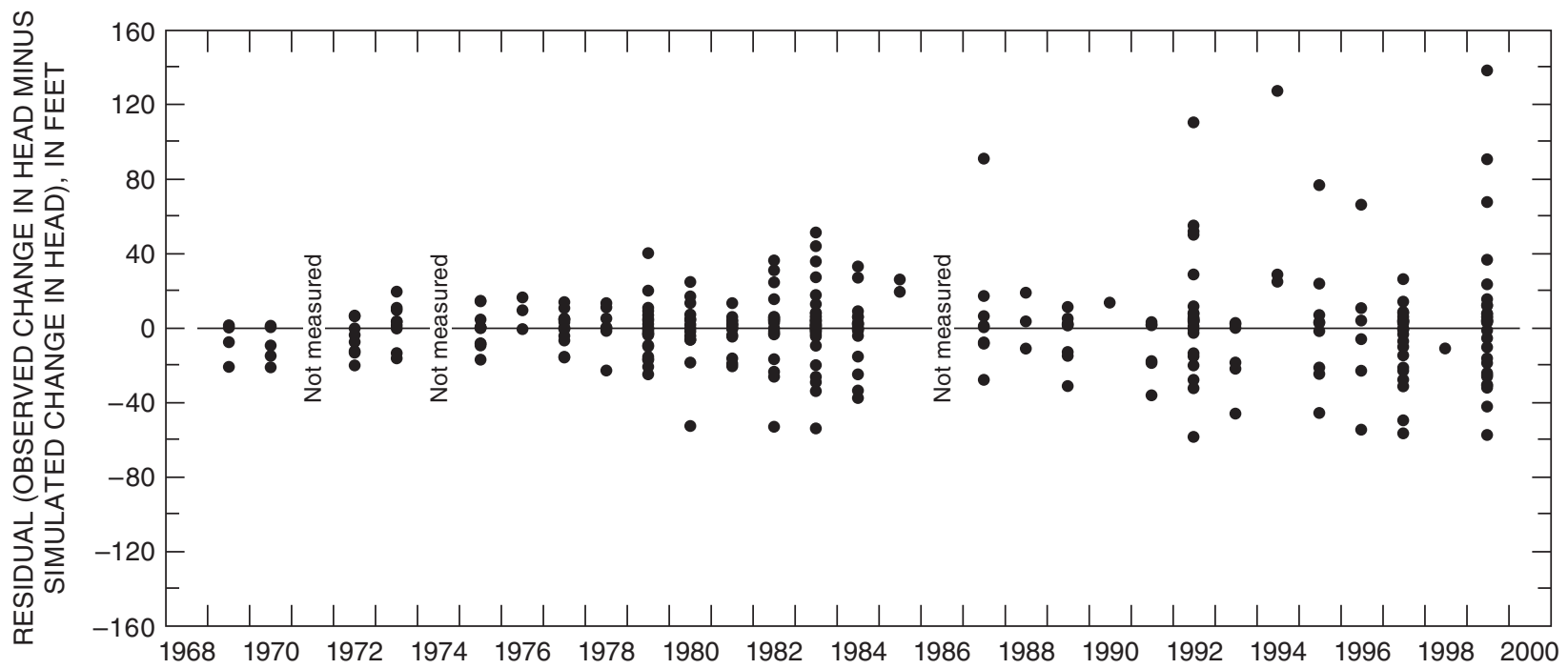

Figure 22. Relation between residuals for changes in heads and year of simulation, Black Mesa area, Arizona.

Composite scaled sensitivities can indicate whether there is enough information in the available observation data to estimate parameters using inverse modeling or traditional calibration techniques (Hill, 1998, p. 38-39). The model sensitivities indicate that there probably is enough information in the available observation data to estimate storage coefficient, transmissivity, and recharge. There might be enough information in the data to estimate conductance of river, drain, and general-head boundaries, and there probably is not enough information in the data to estimate the maximum evapotranspiration rate. It must be emphasized that these statements are only applicable to the 1988 model construction and 1999 observation data set, and that other factors are involved in the success of estimating parameters.

Another statistic that needs to be evaluated to determine whether there is enough information in the available observation data to estimate parameters is the correlation between parameters. Correlations were calculated for the steady-state simulation with only head data and with head and flow data (table 21). Almost all parameter pairs have correlations near 1.0 in the simulation with only head data. This indicates a problem with uniqueness; many models with different parameter values could be developed with similar fits to the head data. Adding flow data improved the correlations for all parameter pairs; however, many pairs still had correlations greater than 0.99 , and the correlation between transmissivity and recharge remained near 1.0. Steady-state heads and flows, therefore, still do not provide enough information to develop a unique model. Linearly coordinated changes in values of transmissivity and recharge could result in similar model fits to the observation data. A possible reason for the small decrease in the correlation between transmissivity and recharge when flow data are included is that only about 40 percent of the total ground-water discharge was estimated and used as flow observations in the model. The total of the estimated flows was $7.5 \mathrm{ft}^{3} / \mathrm{s}$, and the total steady-state outflow was $18.7 \mathrm{ft}^{3} / \mathrm{s}$. Thus, 60 percent of the discharge was not estimated and is not used as a constraint on the model.

Parameter correlations were calculated for the combined steady-state and transient simulations with (1) steady-state heads and transient changes in heads, and with (2) the same head data and flows (table 22). For both sets of observation data, all correlations are small or moderate; the largest correlation coefficient is 0.82 for transmissivity and recharge. 

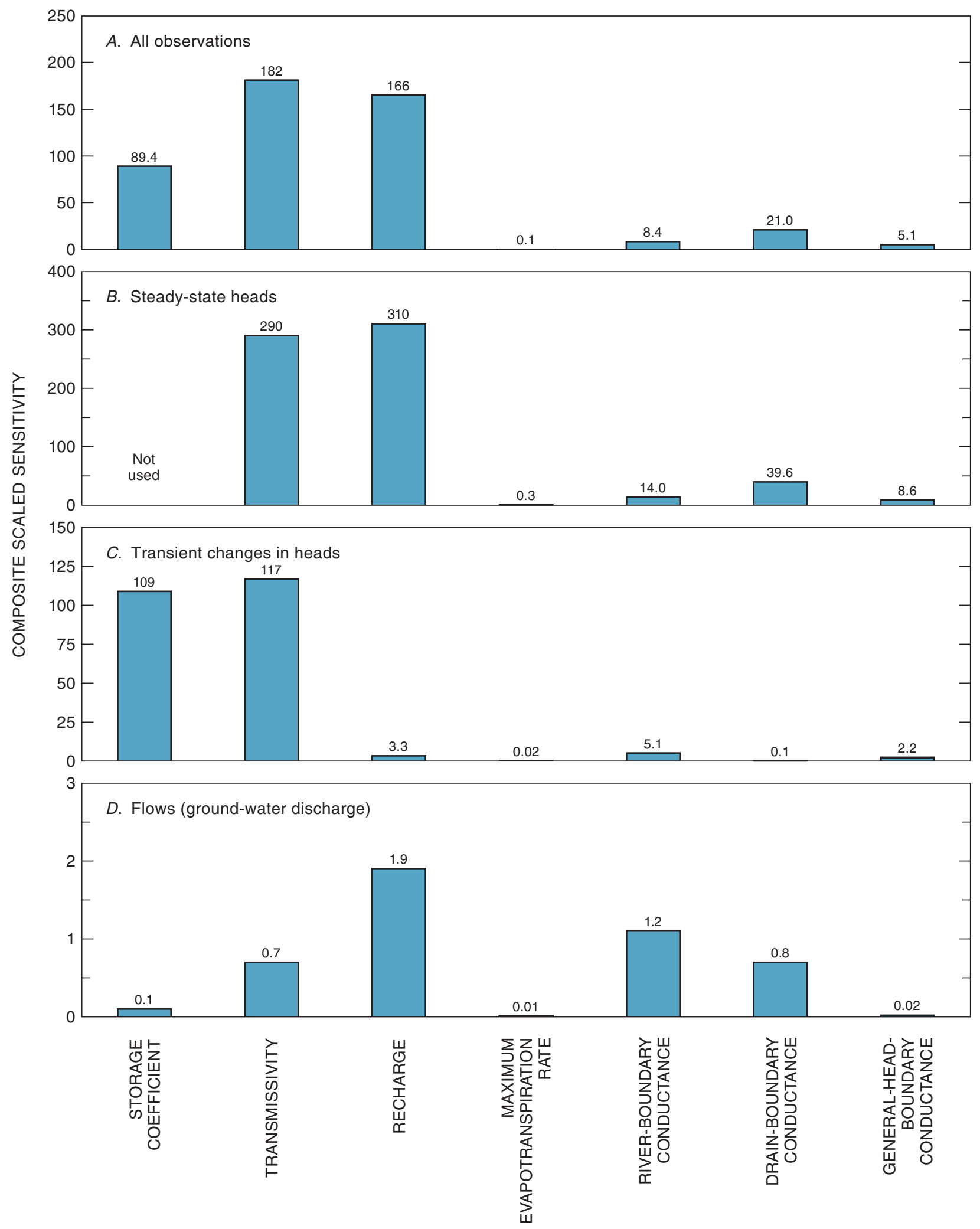

Figure 23. Composite scaled sensitivities for model parameters. $A$, Based on all observations. B, Based on steady-state heads. $C$, Based on transient changes in heads. $D$, Based on flows (ground-water discharge). 
Table 21. Correlation matrices for parameters in steady-state simulations, Black Mesa area, Arizona

A. Correlations computed with steady-state heads

\begin{tabular}{|c|c|c|c|c|c|c|}
\hline Parameter & Transmissivity & Recharge & $\begin{array}{c}\text { Maximum } \\
\text { evapotrans- } \\
\text { piration rate }\end{array}$ & $\begin{array}{l}\text { River-boundary } \\
\text { conductance }\end{array}$ & $\begin{array}{l}\text { Drain-boundary } \\
\text { conductance }\end{array}$ & $\begin{array}{c}\text { General-head- } \\
\text { boundary } \\
\text { conductance }\end{array}$ \\
\hline Transmissivity & 1.0000 & & & & & \\
\hline Recharge & 1.0000 & 1.0000 & & & & \\
\hline Maximum evapotranspiration rate & .9999 & .9999 & 1.0000 & & & \\
\hline River-boundary conductance & 1.0000 & 1.0000 & .9999 & 1.0000 & & \\
\hline Drain-boundary conductance & 1.0000 & 1.0000 & .9999 & 1.0000 & 1.0000 & \\
\hline $\begin{array}{l}\text { General-head-boundary } \\
\text { conductance }\end{array}$ & 1.0000 & 1.0000 & .9999 & 1.0000 & 1.0000 & 1.0000 \\
\hline
\end{tabular}

B. Correlations computed with steady-state heads and flows

\begin{tabular}{|c|c|c|c|c|c|c|}
\hline Parameter & Transmissivity & Recharge & $\begin{array}{c}\text { Maximum } \\
\text { evapotrans- } \\
\text { piration rate }\end{array}$ & $\begin{array}{l}\text { River-boundary } \\
\text { conductance }\end{array}$ & $\begin{array}{c}\text { Drain-boundary } \\
\text { conductance }\end{array}$ & $\begin{array}{c}\text { General-head- } \\
\text { boundary } \\
\text { conductance }\end{array}$ \\
\hline Transmissivity & 1.0000 & & & & & \\
\hline Recharge & .9999 & 1.0000 & & & & \\
\hline Maximum evapotranspiration rate & .2271 & .2277 & 1.0000 & & & \\
\hline River-boundary conductance & .9973 & .9974 & .1867 & 1.0000 & & \\
\hline Drain-boundary conductance & .9998 & .9998 & .2293 & .9968 & 1.0000 & \\
\hline $\begin{array}{l}\text { General-head-boundary } \\
\text { conductance }\end{array}$ & .9923 & .9922 & .2892 & .9887 & .9932 & 1.0000 \\
\hline
\end{tabular}


Table 22. Correlation matrices for parameters in steady-state and transient simulations, Black Mesa area, Arizona

\section{A. Correlations computed with steady-state heads and changes in heads}

\begin{tabular}{|c|c|c|c|c|c|c|c|}
\hline Parameter & $\begin{array}{l}\text { Storage } \\
\text { coefficient }\end{array}$ & Transmissivity & Recharge & $\begin{array}{c}\text { Maximum } \\
\text { evapotrans- } \\
\text { piration rate }\end{array}$ & $\begin{array}{l}\text { River-boundary } \\
\text { conductance }\end{array}$ & $\begin{array}{c}\text { Drain- } \\
\text { boundary } \\
\text { conductance }\end{array}$ & $\begin{array}{c}\text { General-head- } \\
\text { boundary } \\
\text { conductance }\end{array}$ \\
\hline Storage coefficient & 1.0000 & & & & & & \\
\hline Transmissivity & -.5124 & 1.0000 & & & & & \\
\hline Recharge & -.4379 & .8211 & 1.0000 & & & & \\
\hline $\begin{array}{l}\text { Maximum } \\
\text { evapotranspiration rate }\end{array}$ & -.1158 & -.1123 & .1316 & 1.0000 & & & \\
\hline $\begin{array}{l}\text { River-boundary } \\
\text { conductance }\end{array}$ & .0501 & -.1572 & -.0536 & -.3860 & 1.0000 & & \\
\hline $\begin{array}{l}\text { Drain-boundary } \\
\text { conductance }\end{array}$ & -.1331 & .1263 & .0974 & -.0322 & -.1864 & 1.0000 & \\
\hline $\begin{array}{l}\text { General-head-boundary } \\
\text { conductance }\end{array}$ & -.0852 & -.3272 & -.3500 & .5031 & .0029 & .2939 & 1.0000 \\
\hline
\end{tabular}

B. Correlations computed with steady-state heads, changes in heads, and flows

\begin{tabular}{|c|c|c|c|c|c|c|c|}
\hline Parameter & $\begin{array}{c}\text { Storage } \\
\text { coefficient }\end{array}$ & Transmissivity & Recharge & $\begin{array}{l}\text { Maximum } \\
\text { evapotrans- } \\
\text { piration rate }\end{array}$ & $\begin{array}{l}\text { River-boundary } \\
\text { conductance }\end{array}$ & $\begin{array}{c}\text { Drain- } \\
\text { boundary } \\
\text { conductance }\end{array}$ & $\begin{array}{c}\text { General-head- } \\
\text { boundary } \\
\text { conductance }\end{array}$ \\
\hline Storage coefficient & 1.0000 & & & & & & \\
\hline Transmissivity & -.5125 & 1.0000 & & & & & \\
\hline Recharge & -.4378 & .8211 & 1.0000 & & & & \\
\hline $\begin{array}{l}\text { Maximum } \\
\text { evapotranspiration rate }\end{array}$ & -.1157 & -.1124 & .1316 & 1.0000 & & & \\
\hline $\begin{array}{l}\text { River-boundary } \\
\text { conductance }\end{array}$ & .0499 & -.1576 & -.0536 & -.3839 & 1.0000 & & \\
\hline $\begin{array}{l}\text { Drain-boundary } \\
\text { conductance }\end{array}$ & -.1331 & .1263 & .0974 & -.0324 & -.1863 & 1.0000 & \\
\hline $\begin{array}{l}\text { General-head-boundary } \\
\text { conductance }\end{array}$ & -.0851 & -.3272 & -.3502 & .5028 & .0041 & .2939 & 1.0000 \\
\hline
\end{tabular}


From a first look at the parameter correlations calculated using all the observation data (steady-state heads, transient changes in heads, and flows), it would appear that there is no longer a problem of uniqueness of the model because all correlations are small or moderate; however, this analysis is too limited to make this conclusion. No regression analysis or calibration was performed in this study to actually test this conclusion. Parameter sensitivities and correlations are only indicators of the relations between parameters and observation data; there are many more factors involved in determining if observation data are sufficient to accurately estimate parameters and to calibrate a model. Waterstone Environmental Hydrology and Engineering, Inc. (1995) performed a thorough sensitivity analysis of the 1988 USGS model that included using MODFLOWP and a regression analysis to estimate parameters and to calibrate the model. They found a strong correlation between recharge and hydraulic conductivity, and thus transmissivity, using steady-state heads and transient changes in heads through 1993, and they could not simultaneously estimate conductivity and recharge.

The areal distribution of parameter sensitivity is shown in the one-percent sensitivity maps that were calculated for steady-state heads and for changes in head from steady state to 1999. Areas with the largest one-percent sensitivity for a selected parameter have the most information for estimating that parameter, and areas with the smallest sensitivity have the least information. Thus, new data collection to improve estimates of a parameter would likely be the most efficient and effective in the areas with the largest onepercent scaled sensitivity.

Maps of one-percent scaled sensitivity of steadystate heads are shown for the four parameters with the largest composite scaled sensitivity-transmissivity, recharge, river conductance, and drain conductance (fig. 24). The two most important steady-state parameters, transmissivity and recharge, have similar geographic patterns, except the calculated sensitivities have opposite signs. Sensitivities for transmissivity are negative and sensitivities for recharge are positive. Both maps have large values in the principal recharge area near Shonto and the smallest values on the west and northeast sides. Sensitivities for river conductance are largest near Moenkopi Wash near some river cells (fig. 15) and smallest away from the river cells.
Sensitivities for drain conductance are largest on the southwest side of the model near some drain cells (fig. 15) and smallest away from the drain cells.

Maps of one-percent scaled sensitivity of transient changes in head from steady state to 1999 are shown for the four parameters with the largest composite scaled sensitivity-transmissivity, storage coefficient, recharge, and river conductance (fig. 25). Sensitivities for transmissivity are largest in the area of largest withdrawals and largest changes in head--the Peabody well field (figs. 4 and 5). Most sensitivities for transmissivity change sign from confined to unconfined areas. Sensitivities for storage coefficient are largest in the confined south-central and central parts of the model area. They are also large for a few cells in the Tuba City area. Sensitivities for recharge and river conductance generally are small; the largest sensitivities are in the Kayenta area because cells representing recharge and river conductance are nearby (figs. 14 and 15) and there have been appreciable ground-water withdrawals and changes in heads in that area (figs. 4 and 5).

The importance of different wells to the transient simulation was evaluated by ranking the wells according to the dimensionless scaled sensitivity calculated for the observations of changes in heads from steady state to 1999 . The 10 highest ranked wells are shown for the two most important parameters in the transient simulation-transmissivity and storage coefficient (table 23). A well that has an observation with a large dimensionless scaled sensitivity for a selected parameter provides more information about the parameter than a well with a smaller dimensionless scaled sensitivity. Thus, continued collection of head data at the wells listed in table 23 would likely be efficient and productive for improving the estimates of transmissivity and storage coefficient.

The changes in heads from steady state to 1999 in the four continuous observation wells in confined areas (BM observation wells 2, 3, 5, and 6) generally have large dimensionless scaled sensitivities for transmissivity and storage coefficient and thus contain substantial information about those parameters (table 23). The changes in heads from steady state to 1999 in some municipal wells also have large dimensionless scaled sensitivities, so these wells also are important to the estimation of transmissivity and storage coefficient and to a calibration of the model (table 23). 


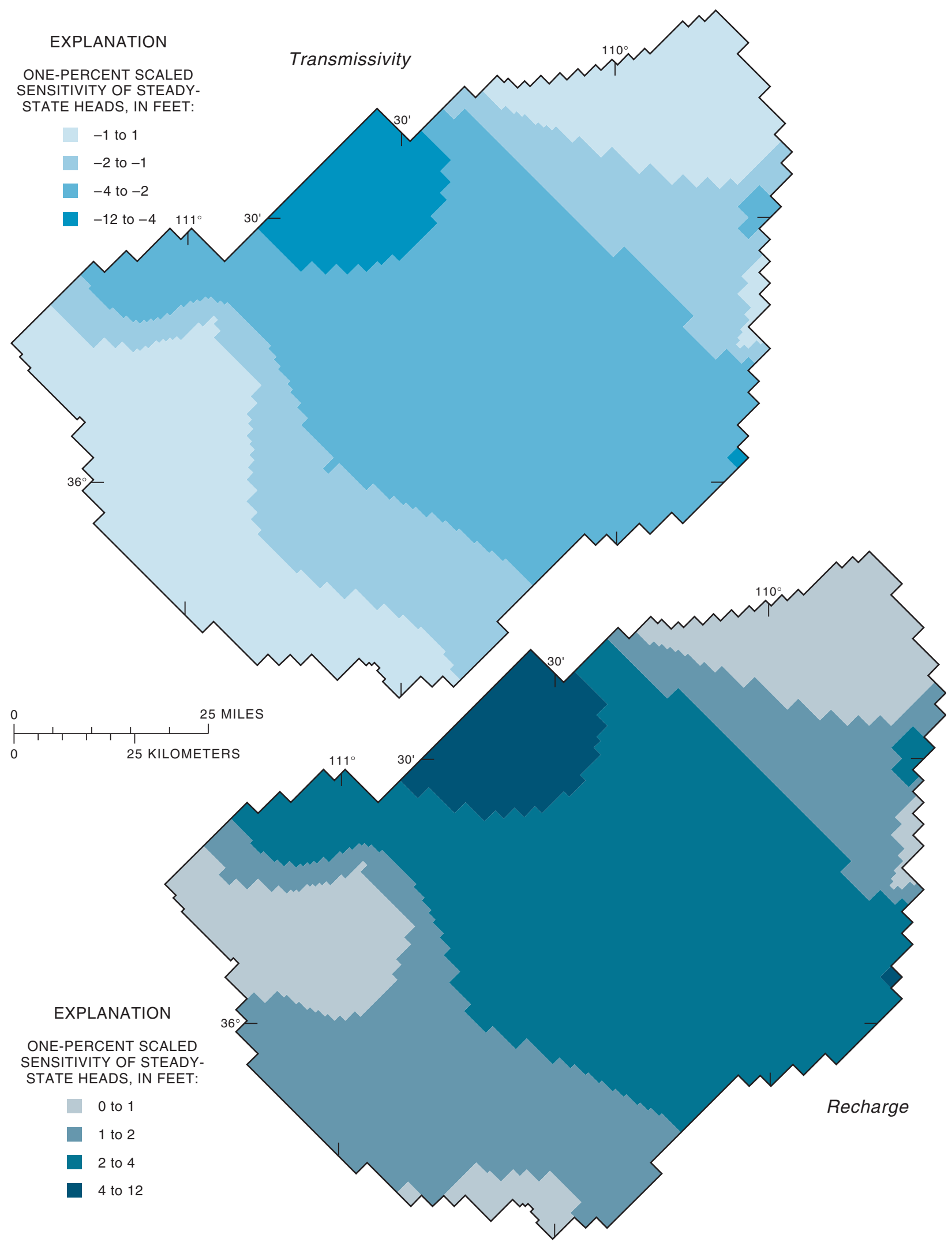

Figure 24. One-percent scaled sensitivity of steady-state heads for transmissivity, recharge, river conductance, and drain conductance, Black Mesa area, Arizona. 
EXPLANATION

ONE-PERCENT SCALED SENSITIVITY OF STEADY STATE HEADS, IN FEET:

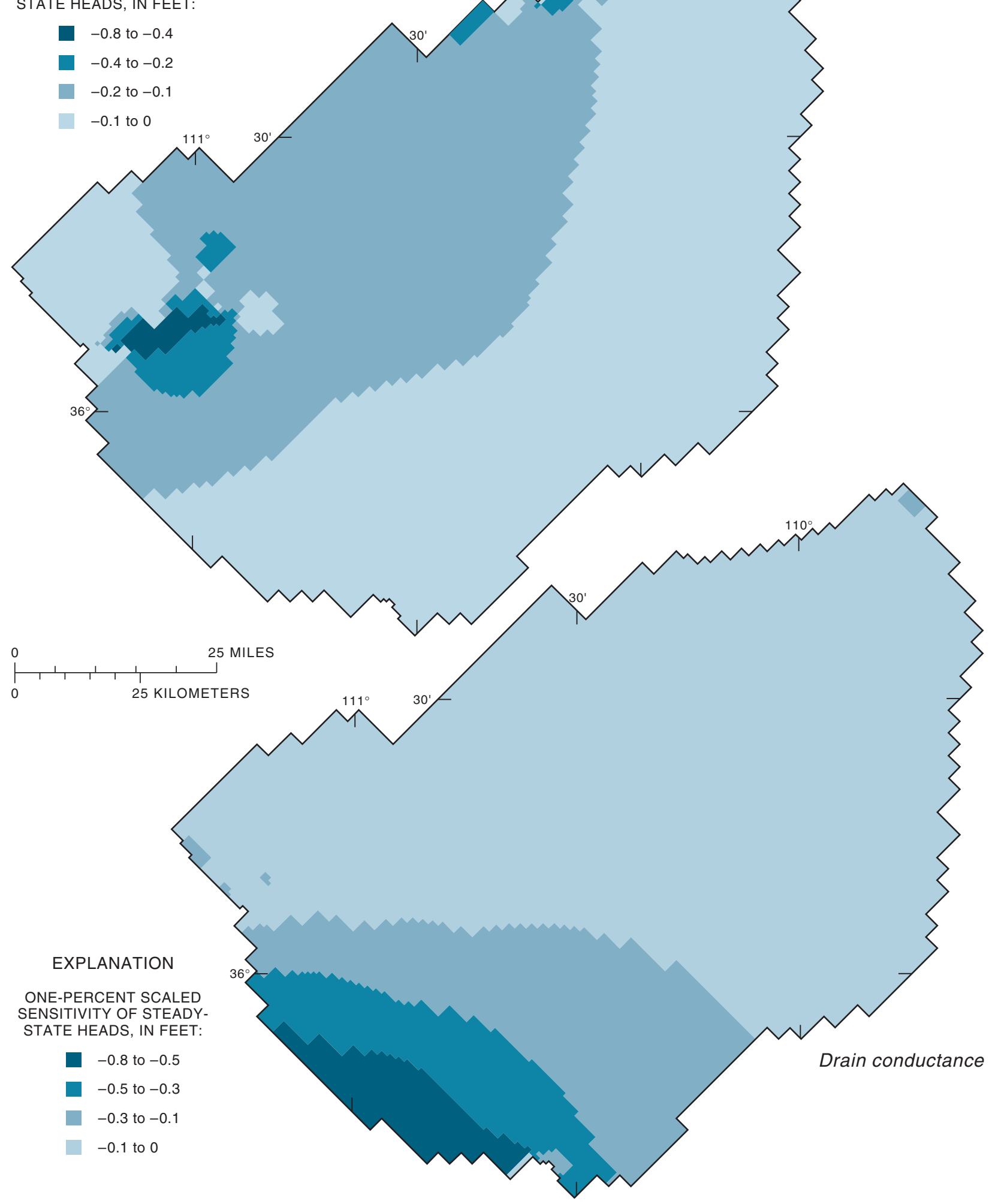

Figure 24. Continued. 


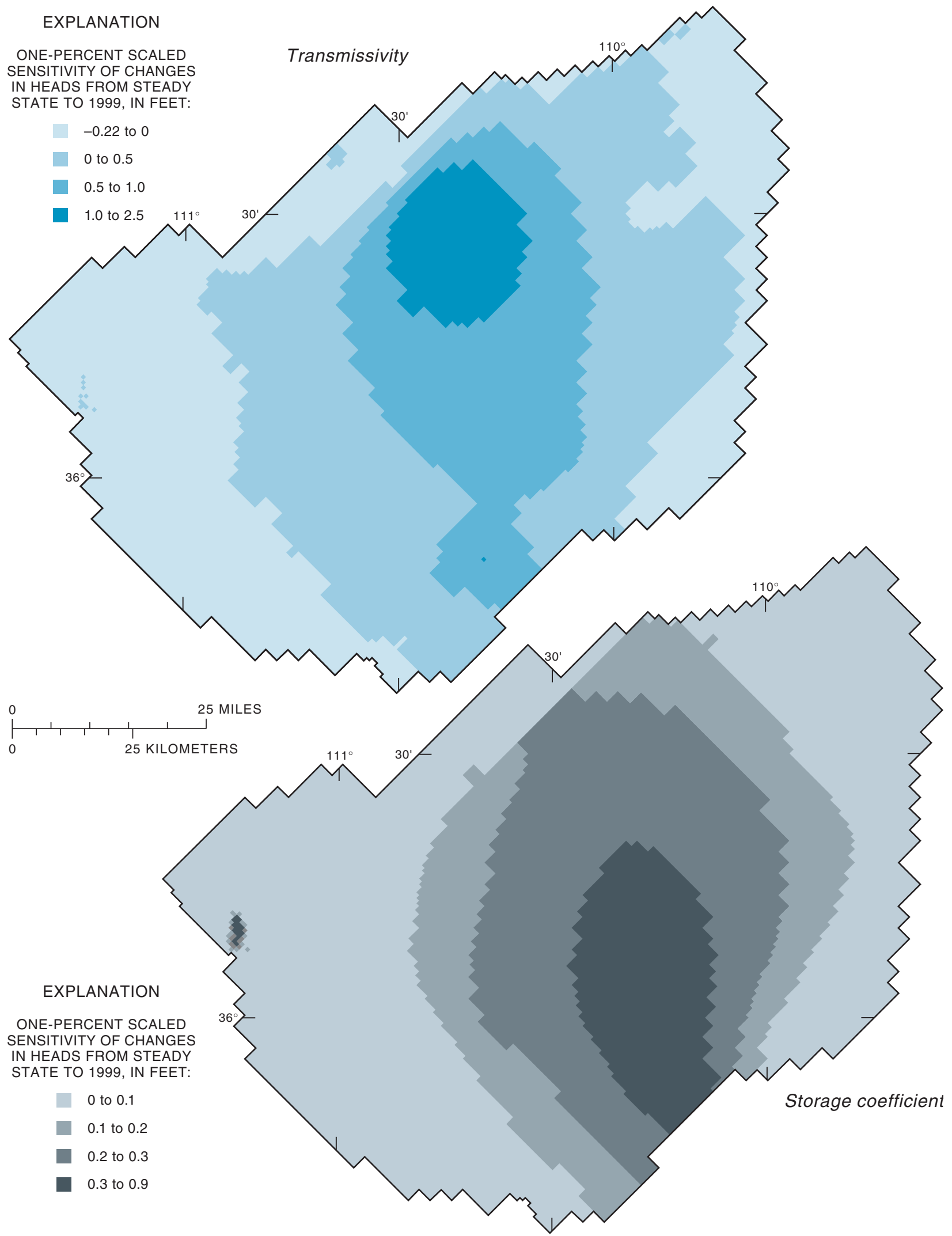

Figure 25. One-percent scaled sensitivity of changes in head from steady state to 1999 for transmissivity, storage coefficient, recharge, and river conductance, Black Mesa area, Arizona. 


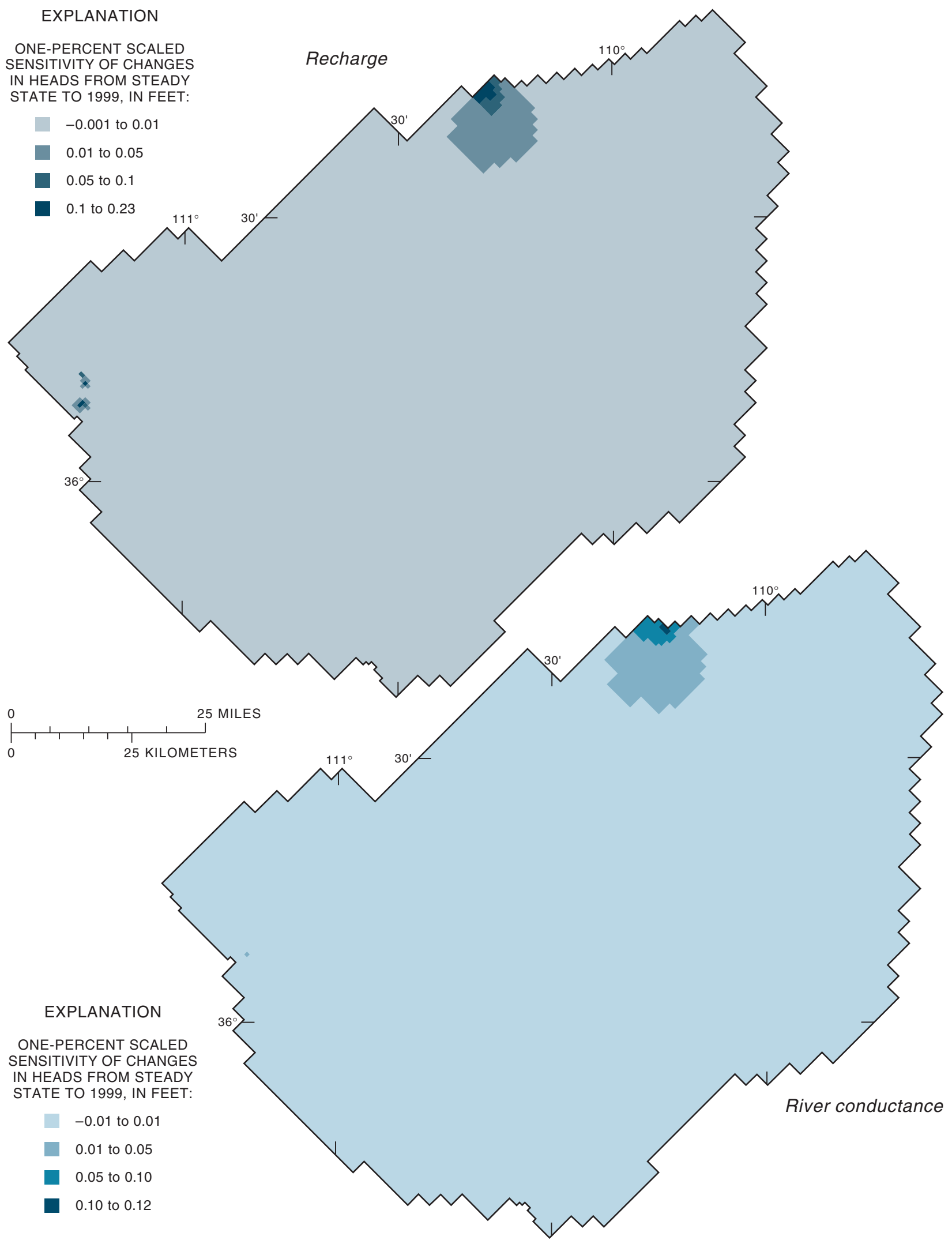

Figure 25. Continued. 
Table 23. The most important wells in terms of sensitivity of changes in heads from steady state to 1999 , for transmissivity and storage coefficient, Black Mesa area, Arizona

[Dimensionless scaled sensitivity indicates the importance of each observation to the estimation of a single parameter or the importance of each parameter to the calculation of a simulated value]

\begin{tabular}{|c|c|c|c|c|c|}
\hline \multirow[b]{2}{*}{ Well name } & \multirow{2}{*}{$\begin{array}{l}\text { Simulated change } \\
\text { in head from } \\
\text { steady state to } 1999, \\
\text { in feet }\end{array}$} & \multicolumn{4}{|c|}{$\begin{array}{l}\text { Dimensionless scaled sensitivity (dss) of change in head from steady state to } \\
1999 \text {, and rank in magnitude of dss for indicated parameter }\end{array}$} \\
\hline & & Transmissivity & Rank & Storage & Rank \\
\hline Keams Canyon PM 2 & -150 & 688 & 1 & 181 & 4 \\
\hline Tuba City NTUA 3 & -181 & 455 & 2 & 514 & 1 \\
\hline BM observation well 6 & -111 & 430 & 3 & -47 & 15 \\
\hline Forest Lake NTUA 1 & -128 & 317 & 4 & -60 & 11 \\
\hline BM observation well 5 & -74 & 260 & 5 & 163 & 5 \\
\hline 3T-508 (Tuba City NTUA 1) & -113 & 254 & 6 & 371 & 3 \\
\hline 3T-546 (Tuba City NTUA 4) & -119 & 215 & 7 & 478 & 2 \\
\hline BM observation well 2 & -50 & 208 & 8 & 83 & 9 \\
\hline BM observation well 3 & -47 & 153 & 9 & 71 & 10 \\
\hline Piñon PM6 & -112 & 99 & 10 & 45 & 16 \\
\hline $2 \mathrm{~T}-502$ & -21 & -16 & 22 & 144 & 6 \\
\hline 3T-333 & -33 & 62 & 11 & 131 & 7 \\
\hline $8 \mathrm{~K}-443$ & -18 & 22 & 18 & 83 & 8 \\
\hline
\end{tabular}

There is a strong correlation between simulated changes in heads from steady state to 1999 and dimensionless scaled sensitivities for transmissivity [significance level $(\alpha)$ is less than 0.01 ] and a weak correlation between simulated changes in heads and sensitivities for storage coefficient [significance level $(\alpha)$ is greater than 0.05; table 23; Sokal and Rohlf, 1973]. The correlation coefficients ( $r$ ) are -0.80 for changes in heads and transmissivity, and -0.42 for changes in heads and storage coefficient. These correlation relations also were seen in the maps of one-percent scaled sensitivity for those parameters.

\section{Potential Revisions, New Data, and Studies to Improve the Model}

The 1988 USGS model of the $\mathrm{N}$ aquifer can be improved by making revisions on the basis of current data and information, and by collecting and analyzing new data. Residual statistics, model sensitivities, and parameter correlations from the analysis in this report and results of previous studies were used to determine the potential revisions, and to determine the potential new data and analyses.

\section{Revisions Based on Current Data and Information}

Current data and information could be used to improve the 1988 USGS model. The 1988 model was constructed with data and information available in 1984. New withdrawal and water-level data from the USGS Black Mesa monitoring program could be used to update the model. Several new geochemical studies (HSIGeoTrans, Inc., 1993; Lopes and Hoffmann, 1997; Zhu and others, 1998; Zhu, 2000; Margot Truini, hydrologist, U.S. Geological Survey, written commun., 2002) and a new three-dimensional ground-water model (HSIGeoTrans, Inc. and Waterstone Environmental Hydrology and Engineering, Inc., 1999) could be used to update and refine the conceptual and numerical model of the $\mathrm{N}$ aquifer.

The 1988 USGS model also could be improved by updating it to new simulation methods, such as MODFLOW-2000 (Harbaugh and others, 2000; Hill and others, 2000). The parameter estimation package of MODFLOW-2000 could be used to test different 
hypotheses about the flow system, to provide more efficient and objective methods of calibration, and to provide quantitative assessments of model uncertainty. The MODPATH program (Pollock, 1994) could be used to facilitate calibration by comparing simulated time of travel with estimates of ground-water ages reported by Lopes and Hoffmann (1997).

Several hypotheses about the ground-water flow system could be tested during the development of a new model. The hypothesis testing would result in a simulation analysis that more accurately describes the knowledge of the system and uncertainties. Parts of the conceptual model used as a basis for the 1988 USGS model have been disputed or questioned by new data or studies (Lopes and Hoffmann, 1997; HSIGeoTrans, Inc. and Waterstone Environmental Hydrology and Engineering, Inc., 1999; and Zhu, 2000). Components of the flow system that need to be investigated include the amount and distribution of recharge, the amount of leakage from overlying formations, the effects of fractures and folds on hydraulic properties, and the lower boundary of the $\mathrm{N}$ aquifer; one alternative concept is that the Wingate Sandstone is intimately connected and can be considered a part of the $\mathrm{N}$ aquifer.

This study identified specific parts of the 1988 USGS model that need improvement. The areal distribution of hydraulic conductivity (fig. 16) could be simplified because it may be more detailed than is justified by field data. There were no obvious regional trends in more than 40 single-well tests or aquifer tests used by Eychaner (1983). Little new data are available on hydraulic properties, but current modeling philosophy emphasizes that areal distributions of hydraulic properties should only be as complex as is justified by field data (Hill, 1998). The boundary that simulates evapotranspiration in the 1988 model has little influence on heads or changes in heads (fig. 23), and thus the maximum evapotranspiration rate of that boundary is difficult to calibrate. Other methods of simulating evapotranspiration, such as the drain boundary, need to be investigated. The southwest boundary of the 1988 model simulates discharge through drains; an alternative boundary might be noflow because there are few known springs in that area. The strong correlation between transmissivity and recharge needs to be decreased to make the model more unique. One possible approach would be to use ground-water ages estimated by Lopes and Hoffmann (1997) as advective-transport target data in calibration.
The lateral boundary of the $\mathrm{N}$ aquifer in the Kayenta area needs to be moved slightly to the north to match new geologic data (HSIGeoTrans, Inc. and Waterstone Environmental Hydrology and Engineering, Inc., 1999).

New 10-meter digital-elevation data can be used to improve estimates of land-surface altitudes for the entire model area. These altitudes would improve the model by providing more accurate estimates of watersurface altitudes for river and drain boundaries and more accurate estimates of evapotranspiration extinction depth.

The 1988 USGS model could be improved with more accurate estimates of ground-water discharge. Discharge estimates could be refined with a detailed analysis of continuous streamflow records for several streams in the study area. Records for Moenkopi Wash are available from 1976 to the current time (2002), records for Chinle Creek are available from 1965 to the current time, and records for Laguna Creek, Dinnebito Wash, Polacca Wash, Oraibi Wash, and Jeddito Wash are available from the mid-1990s to the current time.

The 1988 USGS model could be improved by modifying boundaries and parameters to obtain a better fit to available observation data. This study identified several areas where the model is performing poorly. There is a small overall bias in simulated steady-state heads, a poor fit to most of the estimated flows, and a poor fit to transient changes in heads in some areas. Small adjustments to recharge, hydraulic conductivity, or transmissivity could correct the bias in simulated steady-state heads. The accuracy of the flows estimated in this study is uncertain, so more studies are needed to refine estimates of recharge or discharge before much effort is put into matching the model to the current discharge estimates. Adjustments to transmissivity or storage coefficient could improve the match to observed changes in heads.

\section{New Data and Studies}

The 1988 USGS model could be improved by collecting and analyzing new data. New data or information can be grouped into two categories: (1) observations for use in a model and (2) data and interpretive studies. Observations are a certain kind of data that are used to calibrate a model, to assess performance, and to estimate parameters in inverse modeling. Examples of observations are hydraulic heads, flows, or estimates of advective transport. Data and interpretive studies are used to estimate the model boundaries, internal hydraulic properties, and water budget. Examples of data are geophysical data, 
lithologic data, geochemical data, and precipitation. Examples of interpretive studies are geologic studies that define physical boundaries of an aquifer, waterbudget studies that estimate recharge, or aquifer tests that estimate transmissivity and storage.

Results of this study indicate that observations of steady-state heads, changes in heads, and flows provide important information for improving the model. New observations of steady-state heads are not possible in most of the model area because withdrawals have created transient-state conditions. Heads in the Shonto area, however, have remained fairly stable during the last 30 years (figs. 5 and 7), so new observations of heads in that area could be considered close to steady state, and they would provide information about recharge and transmissivity (figs. 23 and 24).

Observations of changes in heads would be most beneficial in the areas of most stress, including near the Peabody well field, most of the confined area, and near Tuba City. These change-in-head observations provide the most information for estimating transmissivity and storage coefficient (fig. 23). Observations or estimates of ground-water discharge also are needed for improving the model. These discharges can be used for calibration targets, constraining information for the water-budget magnitude, assessing changes in discharge over time, and decreasing the correlation between recharge and transmissivity.

New data and interpretive studies are needed to improve the understanding of all components of the $\mathrm{N}$ aquifer. A general order of priority for components of the $\mathrm{N}$ aquifer, listed in order of importance and level of uncertainty, is: (1) ground-water recharge from precipitation, (2) recharge by leakage from the D aquifer, (3) ground-water discharge, (4) hydraulic conductivity, (5) storage coefficient, (6) hydraulic characteristics of the Carmel confining unit, (7) characteristics of the lower boundary, (8) vertical head gradients and vertical flow within the entire ground-water system between the Mancos Shale and Chinle Formation, (9) changes in ground-water discharge over time, and (10) extent of lateral and altitude of upper boundaries.

Ground-water recharge from precipitation has a strong influence on steady-state heads and groundwater discharge (fig. 23). In addition, recharge is strongly correlated to transmissivity and thus is an important factor in the uniqueness of a ground-water model of the $\mathrm{N}$ aquifer. Possible studies that could improve the understanding of recharge include studies of daily water budgets of watersheds, environmental tracers, or geophysical data. An additional benefit of recharge studies might be to determine if bare soil or bare-rock outcrops are areas of net recharge or net discharge.

Recent geochemical data (Lopes and Hoffmann, 1997) and the recent three-dimensional ground-water model (HSIGeoTrans, Inc. and Waterstone Environmental Hydrology and Engineering, Inc., 1999) indicate that recharge by leakage from the $\mathrm{D}$ aquifer could be appreciable. Possible studies or new data that could improve the understanding of leakage include studies of geochemical data, geophysical data, and water-level and hydraulic-property data from new wells that could be completed in and near the Carmel confining unit.

Ground-water discharge data are important to constrain ground-water models, and discharge estimates also help to decrease the correlation coefficient between recharge and transmissivity. The understanding of discharge could be improved with a comprehensive inventory of springs in the model area, studies of environmental tracers, studies of evapotranspiration from cliff faces, and detailed studies of hydraulic gradients, water temperatures, and hydraulic characteristics at sites of stream/aquifer interactions.

Transmissivity (or hydraulic conductivity) of the $\mathrm{N}$ aquifer strongly influences steady-state heads and transient changes in heads, and storage coefficient strongly influences transient changes in heads (fig. 23). Aquifer tests, geophysical studies, and analyses of core samples and lithology from existing and new wells could improve the understanding of transmissivity, hydraulic conductivity, and storage coefficient.

Characteristics of the Carmel confining unit influence the amount and timing of leakage from the $\mathrm{D}$ to the $\mathrm{N}$ aquifer. Geophysical studies, aquifer tests, and analyses of core samples and lithology from existing and new wells could improve the understanding of the Carmel confining unit.

Characteristics of the lower boundary of the $\mathrm{N}$ aquifer are important. The altitude of the lower boundary influences the magnitude of transmissivity and the amount of available storage in the aquifer. Geophysical studies could be used to better estimate the altitude of the boundary. The formations that are included in the $\mathrm{N}$ aquifer are important. The recent three-dimensional ground-water model (HSIGeoTrans, Inc. and Waterstone Environmental Hydrology and Engineering, Inc., 1999) includes most of the Wingate Sandstone, and the 1988 USGS model includes only a small part of the Wingate Sandstone. Studies of water- 
level data, geophysical data, and lithology from wells could provide information to determine if the Wingate Sandstone should be included in the $\mathrm{N}$ aquifer.

The $\mathrm{N}$ aquifer is more than one geologic formation and it is part of a larger ground-water system between the Mancos Shale and Chinle Formation (fig. 2). It is, therefore, important to understand the vertical head gradients and the amount of vertical flow within the $\mathrm{N}$ aquifer and in the entire ground-water system. Water-level and geochemical data from existing wells and from new vertically nested wells could improve the understanding of vertical gradients and vertical flow.

One of the possible effects of ground-water withdrawals is a decrease in ground-water discharge over time. New data and studies are needed to independently determine if discharges have changed or will change in the future. Data and studies also are needed to distinguish between the changes caused by natural fluctuations in recharge and changes caused by withdrawals. Continuous measurements of discharge to springs and streams, and measurements of factors affecting recharge, such as precipitation, evapotranspiration, and runoff, could improve the understanding of changes in discharge over time.

The lateral and upper boundaries of the $\mathrm{N}$ aquifer influence the total water budget and flow conditions near the boundaries. Existing surficial geologic mapping and lithologic data in wells are sufficient to define the physical extent (lateral boundary) and the altitude of the upper boundary. Head data from existing and new wells in the northwestern part of the study area could be used to refine the location of the ground-water divide that is used as a no-flow boundary in the 1988 USGS model.

\section{SUMMARY}

The $\mathrm{N}$ aquifer is the major source of water for industrial and municipal users in the Black Mesa area of northeastern Arizona. Availability of water is an important issue in the Black Mesa area because of continued industrial and municipal use, a growing population, and precipitation of about 6 to $14 \mathrm{in} / \mathrm{yr}$.

This report presents results of ground-water, surface-water, and water-chemistry monitoring in the Black Mesa area from January 2000 to June 2001. The monitoring data for 2000-2001 are compared with data for 1999 and with historical data from the 1950s to the present. This report also presents results of an analysis of the performance and sensitivity of a numerical model of the $\mathrm{N}$ aquifer developed by the USGS in 1988. The performance analysis was done to determine how well the model has simulated waterlevel observation data collected since the model was constructed. The sensitivity analysis was done to determine relations among the model parameters, observation data, and simulated values. The performance and sensitivity analysis is also a logical first step for updating and improving the 1988 model.

In 2000, total ground-water withdrawals were 7,740 acre-ft, industrial use was 4,490 acre-ft, and municipal use was 3,250 acre-ft. From 1999 to 2000, total withdrawals increased by 9 percent, municipal use increased by 12 percent, and industrial use increased by 7 percent. During the past 10 years, total withdrawals and municipal and industrial use increased at an average rate of about 3 percent per year.

From 1999 to 2001, ground-water levels declined in 18 of 31 wells. The median water-level change for the 31 wells was $-0.4 \mathrm{ft}$, and changes ranged from $-10.8 \mathrm{ft}$ to $+6.0 \mathrm{ft}$. In unconfined areas of the $\mathrm{N}$ aquifer, water levels declined in 10 of 15 wells, and the median change was $-0.4 \mathrm{ft}$. In confined areas, water levels declined in 8 of 16 wells, and the median change was $-0.2 \mathrm{ft}$.

For wells in confined areas of the $\mathrm{N}$ aquifer, there is a significant decreasing trend in the median annual water-level changes from 1983 to 2001, and the average annual median change was $+0.2 \mathrm{ft}$. For wells in confined areas, there is no significant trend in the median annual water-level changes, and the average annual median change was $-1.8 \mathrm{ft}$.

From the prestress period (prior to 1965) to 2001, water levels in 33 wells changed by a median of $-17.2 \mathrm{ft}$. Water levels in the 15 wells in the unconfined part of the $\mathrm{N}$ aquifer had a median change of $-1.2 \mathrm{ft}$, and the changes ranged from $-39 \mathrm{ft}$ to $+6.3 \mathrm{ft}$. Water levels in the 18 wells in the confined part of the aquifer had a median change of $-31.0 \mathrm{ft}$, and the changes ranged from $-168.8 \mathrm{ft}$ to $+9.4 \mathrm{ft}$.

Discharges were measured annually at four springs in 1999 and 2001. Burro Spring had a 33 percent decrease in discharge, the unnamed spring near Dennehotso had an 81-percent increase, Moenkopi School Spring had a 3-percent increase, and Pasture Canyon Spring had a 5-percent decrease. For about the past 10 years, discharges did not significantly change in Burro Spring, the unnamed spring near Dennehotso, 
and Moenkopi School Spring. The record of discharge from a consistent measuring point for Pasture Canyon Spring is too short for a statistical analysis of trends.

The annual average discharges at the four streamflow-gaging stations vary considerably during their periods of record. Continuous records of surfacewater discharge have been collected from July 1976 to 2000 at Moenkopi Wash, July 1996 to 2000 at Laguna Creek, June 1993 to 2000 at Dinnebito Wash, and April 1994 to 2000 at Polacca Wash.

The records for Laguna Creek, Dinnebito Wash, and Polacca Wash are too short for a statistical analysis of trends. There is no significant trend in the annual average discharges for Moenkopi Wash from 1977 to 2000. Median flows for November, December, January, and February of each water year are used as an index of ground-water discharge to those streams. There is no significant trend in the median winter flows for Moenkopi Wash from 1977 to 2000. The records for the other three streams are too short for a statistical analysis of trends. The median winter flows for Dinnebito Wash and Polacca Wash, however, appear to have decreased during the last 6 years. There is no apparent trend in the median winter flows for Laguna Creek since 1997.

In 2001, water samples were collected from 12 wells and analyzed for selected chemical constituents. Dissolved-solids concentrations ranged from 102 to $628 \mathrm{mg} / \mathrm{L}$, and samples from 8 of the wells had dissolved-solids concentrations less than $300 \mathrm{mg} / \mathrm{L}$. From about the mid-1980s or early 1990s to 2001, there are no significant trends in the concentrations of dissolved solids, chloride, and sulfate in water samples from 6 of the 7 wells with sufficient years of record for a statistical test. The concentration of one tested constituent (dissolved solids) in samples from Rocky Ridge PM3 significantly increased from 1990 to 2001.

Dissolved-solids concentrations in water samples from the unnamed spring near Dennehotso, Pasture Canyon Spring, and Moenkopi School Spring ranged from 116 to $194 \mathrm{mg} / \mathrm{L}$, and dissolved-solids concentration in the water sample from Burro Spring was $348 \mathrm{mg} / \mathrm{L}$. From the late 1980s to 2001, there are no significant tends in the concentrations of dissolved solids, chloride, and sulfate in water samples from Burro Spring, the unnamed spring near Dennehotso, and Pasture Canyon Spring. From 1987 to 2001, concentrations of chloride and sulfate significantly increased in water samples from Moenkopi School Spring and concentrations of dissolved solids did not significantly change.

The performance and sensitivity of the 1988 USGS numerical model of the $\mathrm{N}$ aquifer were analyzed. The overall performance of the model for steady-state conditions is reasonable for residuals of heads (difference between observed and simulated steady-state heads). The mean residual for steady-state heads is $5.3 \mathrm{ft}$, median residual is $-0.2 \mathrm{ft}$, root mean square error of residuals is $35 \mathrm{ft}$, and 80 percent of the absolute values of residuals are less than $38 \mathrm{ft}$. There is a small overall positive bias and a small positive areal bias in the Shonto, west-central, and Tuba City areas. Positive bias is where simulated heads are consistently lower than observed heads. Simulated flows are about 40 percent different than estimated flows at 2 of 3 discharge areas simulated in the model; however, this comparison is only a rough approximation of performance because the accuracy of the estimated flows is uncertain.

The overall performance of the model for transient conditions is fair for residuals of changes in head (difference between observed and simulated changes in head); the mean residual for changes in head from steady state to 1999 is $4.3 \mathrm{ft}$, median residual is $3.6 \mathrm{ft}$, root mean square error of residuals is $40 \mathrm{ft}$, and 80 percent of the absolute values of residuals are less than $31 \mathrm{ft}$. The model is biased in two areas. In the Tuba City area, simulated changes in head are much more negative than observed changes in head; all six residuals are positive and three residuals are between 75 and $155 \mathrm{ft}$. In the confined area of the $\mathrm{N}$ aquifer, observed changes in head are more negative than simulated changes in head; 12 of the 17 residuals are negative and 8 residuals are between -57 and $-20 \mathrm{ft}$.

Analysis of model sensitivity indicates that recharge, transmissivity, and storage coefficient are the most important parameters for estimating heads, changes in heads, and flows. A strong correlation between recharge and transmissivity and a lack of independent and reliable estimates of recharge, transmissivity, and discharge create a uniqueness problem in model calibration. Several models could be constructed and calibrated with different values of recharge or transmissivity and still have similar fits to the observation data. The amount of simulated evapotranspiration is uncertain because available 
observation data are insensitive to the maximum evapotranspiration parameter in the model and there are no independent estimates of evapotranspiration.

Information from recent data and studies and more advanced modeling techniques could be used to develop a more representative and less uncertain model. The most useful objectives of future data collection and studies would be to obtain better estimates of recharge, discharge, transmissivity, and storage coefficient. Additional observation data (heads, changes in heads, and flows) would be the most useful in the recharge area near Shonto, discharge areas of Moenkopi Wash and Laguna Creek, and areas of most stress (withdrawals), such as Kayenta and the central, south-central, and Tuba City areas.

\section{SELECTED REFERENCES}

Anderman, E.R., and Hill, M.C., 1997, Advective-transport observation (ADV) package, a computer program for adding advective-transport observations of steady-state flow fields to the three-dimensional ground-water flow parameter-estimation model MODFLOWP: U.S. Geological Survey Open-File Report 97-14, 67 p.

Boner, F.C., Davis, R.G., and Duet, N.R., 1992, Water resources data for Arizona, water year 1991: U.S. Geological Survey Water-Data Report AZ-91-1, 411 p.

Boner, F.C., Garrett, W.B., and Konieczki, A.D., 1989, Water-resources data for Arizona, water year 1988: U.S. Geological Survey Water-Data Report AZ-88-1, $391 \mathrm{p}$.

Boner, F.C., Konieczki, A.D., and Davis, R.G., 1991, Water-resources data for Arizona, water year 1990: U.S. Geological Survey Water-Data Report AZ-90-1, $381 \mathrm{p}$.

Boner, F.C., Smith, C.F., Garrett, W.B., and Konieczki, A.D., 1990, Water-resources data for Arizona, water year 1989: U.S. Geological Survey Water-Data Report AZ-89-1, 383 p.

Brown, J.G., and Eychaner, J.H., 1988, Simulation of five ground-water withdrawal projections for the Black Mesa area, Navajo and Hopi Indian Reservations, Arizona: U.S. Geological Survey Water-Resources Investigations Report 88-4000, 51 p.

Conover, W.J., 1980, Practical nonparametric statistics (2d ed.): New York, John Wiley and Sons, 493 p.

Cooley, M.E., Harshbarger, J.W., Akers, J.P., and Hardt, W.F., 1969, Regional hydrogeology of the Navajo and Hopi Indian Reservations, Arizona, New Mexico, and Utah: U.S. Geological Survey Professional Paper 521-A, 61 p.
Davis, G.E., Hardt, W.F., Thompson, L.K., and Cooley, M.E., 1963, Records of ground-water supplies, part 1, of Geohydrologic data in the Navajo and Hopi Indian Reservations, Arizona, New Mexico, and Utah: Arizona State Land Department Water-Resources Report 12-A, $159 \mathrm{p}$.

Dubiel, R.F., 1989, Sedimentology and revised nomenclature for the upper part of the upper Triassic Chinle Formation and the lower Jurassic Wingate Sandstone, northwestern New Mexico and northeastern Arizona, in Anderson, O.J., Lucas, S.G., Love, D.W., and Cather, S.M., eds., Southeastern Colorado Plateau: New Mexico Geological Society Fortieth Annual Field Conference, September 28-October 1, 1989, p. 213-223.

Eychaner, J.H., 1983, Geohydrology and effects of water use in the Black Mesa area, Navajo and Hopi Indian Reservations, Arizona: U.S. Geological Survey WaterSupply Paper 2201, 26 p.

GeoTrans, Inc., 1987, A two-dimensional finite-difference flow model simulating the effects of withdrawals to the $\mathrm{N}$ aquifer, Black Mesa area, Arizona: Boulder, Colorado, GeoTrans, Inc., report prepared for Peabody Western Coal Company.

Harshbarger, J.W., Lewis, D.D., Skibitzke, H.E., Heckler, W.L., and Kister, L.R., 1966, Arizona Water: U.S. Geological Survey Water-Supply Paper 1648, 85 p.

Harbaugh, A.W., Banta, E.R., Hill, M.C., and McDonald, M.G., 2000, MODFLOW-2000, the U.S. Geological Survey modular ground-water model-User guide to modularization concepts and the ground-water flow process: U.S. Geological Survey Open-File Report 00-92, $121 \mathrm{p}$.

Hart, R.J., and Sottilare, J.P., 1988, Progress report on the ground-water, surface-water, and quality-of-water monitoring program, Black Mesa area, northeastern Arizona-1987-88: U.S. Geological Survey Open-File Report 88-467, 27 p. 1989, Progress report on the ground-water, surfacewater, and quality-of-water monitoring program, Black Mesa area, northeastern Arizona-1988-89: U.S. Geological Survey Open-File Report 89-383, 33 p.

Hill, G.W., 1985, Progress report on Black Mesa monitoring program-1984: U.S. Geological Survey Open-File Report 85-483, 24 p.

Hill, G.W., and Sottilare, J.P., 1987, Progress report on the ground-water, surface-water, and quality-of-water monitoring program, Black Mesa area, northeastern Arizona-1987: U.S. Geological Survey Open-File Report 87-458, 29 p.

Hill, G.W., and Whetten, M.I., 1986, Progress report on Black Mesa monitoring program-1985-86: U.S. Geological Survey Open-File Report 86-414, 23 p. 
Hill, M.C., 1992, A computer program (MODFLOWP) for estimating parameters of a transient, three-dimensional, ground-water flow model using nonlinear regression: U.S. Geological Survey Open-File Report 91-484, $358 \mathrm{p}$.

1998, Methods and guidelines for effective model calibration: U.S. Geological Survey Water-Resources Investigations Report 98-4005, 90 p.

Hill, M.C., Banta, E.R., Harbaugh, A.W., and Anderman, E.R., 2000, MODFLOW-2000, the U.S. Geological Survey modular ground-water model-User guide to the observation, sensitivity, and parameter-estimation process and three post-processing programs: U.S. Geological Survey Open-File Report 00-184, 209 p.

HSIGeoTrans, Inc., 1993, Investigation of the N- and Daquifer geochemistry and flow characteristics using major ion and isotopic chemistry, petrography, rock stress analyses, and dendrochronology in the Black Mesa area, Arizona: Boulder, Colorado, HSIGeoTrans, Inc., report prepared for Peabody Coal Company.

HSIGeoTrans, Inc., and Waterstone Environmental Hydrology and Engineering, Inc., 1999, A threedimensional flow model of the $\mathrm{D}$ and $\mathrm{N}$ aquifers, Black Mesa Basin, Arizona: Boulder, Colorado, HSIGeoTrans, Inc., and Waterstone Environmental Hydrology and Engineering, Inc., report prepared for Peabody Western Coal Company.

Kister, L.R., and Hatchett, J.L., 1963, Selected chemical analyses of the ground water, part 2, of Geohydrologic data in the Navajo and Hopi Indian Reservations, Arizona, New Mexico, and Utah: Arizona State Land Department Water-Resources Report 12-B, 58 p.

Konikow, L.F., and Bredehoeft, J.D., 1992, Ground-water models cannot be validated: Advances in Water Resources, v. 15, no. 1, p. 75-83.

Littin, G.R., 1992, Results of ground-water, surface-water, and water-quality monitoring, Black Mesa area, northeastern Arizona-1990-91: U.S. Geological Survey Water-Resources Investigations Report 92-4045, 32 p.

1993, Results of ground-water, surface-water, and water-quality monitoring, Black Mesa area, northeastern Arizona-1991-92: U.S. Geological Survey Water-Resources Investigations Report 93-4111, 23 p.

Littin, G.R., Baum, B.M., and Truini, Margot, 1999, Ground-water, surface-water, and water-chemistry data, Black Mesa area, northeastern Arizona-1999: U.S. Geological Survey Open-File Report 98-653, 27 p.

Littin, G.R., and Monroe, S.A., 1995a, Results of groundwater, surface-water, and water-quality monitoring, Black Mesa area, northeastern Arizona-1992-93: U.S. Geological Survey Water-Resources Investigations Report 95-4156, 37 p.
$1995 \mathrm{~b}$, Results of ground-water, surface-water, and water-chemistry monitoring, Black Mesa area, northeastern Arizona-1994: U.S. Geological Survey Water-Resources Investigations Report 95-4238, $25 \mathrm{p}$.

1996, Ground-water, surface-water, and waterchemistry data, Black Mesa area, northeastern Arizona-1995: U.S. Geological Survey Open-File Report 96-616, 22 p.

1997, Ground-water, surface-water, and waterchemistry data, Black Mesa area, northeastern Arizona-1996: U.S. Geological Survey Open-File Report 97-566, 27 p.

Lopes, T.J., and Hoffmann, J.P., 1997, Geochemical analyses of ground-water ages, recharge rates, and hydraulic conductivity of the N Aquifer, Black Mesa area, Arizona: U.S. Geological Survey Water-Resources Investigations Report 96-4190, 42 p.

McDonald, M.G., and Harbaugh, A.W., 1984, A modular three-dimensional finite-difference ground-water flow model: U.S. Geological Survey Open-File Report 83-875, $528 \mathrm{p}$.

Papadopulos, S.S. and Associates, Inc., 1993, Navajo aquifer water study, final report, prepared for Hopi Tribe, Navajo Nation, and Peabody Coal Company: Bethesda, Maryland, Papadopulos and Associates, Inc., 49 p.

Peterson, Fred, 1988, Stratigraphy and nomenclature of middle and upper Jurassic rocks, Western Colorado Plateau, Utah and Arizona, in Revisions to stratigraphic nomenclature of Jurassic and Cretaceous rocks of the Colorado Plateau: U.S. Geological Survey Bulletin 1633-B, p. 13-56.

Pollock, D.W., 1994, User's guide for MODPATH/MODPATH-PLOT, Version 3: A particle tracking post-processing package for MODFLOW, the U.S. Geological Survey finite-difference ground-water flow model: U.S. Geological Survey Open-File Report 94-464, 6 ch.

Smith, C.F., Anning, D.W., Duet, N.R., Fisk, G.G., McCormack, H.F., Pope, G.L., Rigas, P.D., and Wallace, B.L., 1995, Water resources data for Arizona, water year 1994: U.S. Geological Survey Water-Data Report AZ-94-1, 320 p.

Smith, C.F., Boner, F.C., Davis, R.G., Duet, N.R., and Rigas, P.D., 1993, Water resources data for Arizona, water year 1992: U.S. Geological Survey Water-Data Report AZ-92-1, $360 \mathrm{p}$.

Smith, C.F., Rigas, P.D., Ham, L.K., Duet, N.R., and Anning, D.W., 1994, Water resources data for Arizona, water year 1993: U.S. Geological Survey Water-Data Report AZ-93-1, 360 p. 
Smith, C.F., Duet, N.R., Fisk, G.G., McCormack, H.F., Partin, C.K., Pope, G.L., Rigas, P.D., and Tadayon, Saeid, 1996, Water resources data for Arizona, water year 1995: U.S. Geological Survey Water-Data Report AZ-95-1, 306 p.

Smith, C.F., Duet, N.R., Fisk, G.G., McCormack, H.F., Partin, C.K., Pope, G.L., and Rigas, P.D., 1997, Water resources data for Arizona, water year 1996: U.S. Geological Survey Water-Data Report AZ-96-1, 328 p.

Sokal, R.R., and Rohlf, F.J., 1973, Introduction to biostatistics: San Francisco, W.H. Freeman and Company, $368 \mathrm{p}$.

Sottilare, J.P., 1992, Results of ground-water, surface-water, and water-quality monitoring, Black Mesa area, northeastern Arizona-1989-90: U.S. Geological Survey Water-Resources Investigations Report 92-4008, 38 p.

Tadayon, Saeid, Duet, N.R., Fisk, G.G., McCormack, H.F., Pope, G.L., and Rigas, P.D., 1998, Water resources data for Arizona, water year 1997: U.S. Geological Survey Water-Data Report AZ-97-1, 416 p.

Tadayon, Saeid, Duet, N.R., Fisk, G.G., McCormack, H.F., Partin, C.K., Pope, G.L., and Rigas, P.D., 1999, Water resources data for Arizona, water year 1998: U.S. Geological Survey Water-Data Report AZ-98-1, 454 p.

Tadayon, Saeid, Duet, N.R., Fisk, G.G., McCormack, H.F., Partin, C.K., Pope, G.L., and Rigas, P.D., 2000, Water resources data for Arizona, water year 1999: U.S. Geological Survey Water-Data Report AZ-99-1, 470 p.

Tadayon, Saeid, Duet, N.R., Fisk, G.G., McCormack, H.F., Partin, C.K., Pope, G.L., and Rigas, P.D., 2001, Water resources data for Arizona, water year 2000: U.S. Geological Survey Water-Data Report AZ-00-1, 390 p.

Thomas, B.E., and Truini, Margot, 2000, Ground-water, surface-water, and water-chemistry data, Black Mesa area, northeastern Arizona-1999: U.S. Geological Survey Open-File Report 00-453, 42 p.

Truini, Margot, Baum, B.M., Littin, G.R., and SingoitewaHonanie, Gayl, 2000, Ground-water, surface-water, and water-chemistry data, Black Mesa area, northeastern Arizona-1998: U.S. Geological Survey Open-File Report 00-66, 37 p.

U.S. Environmental Protection Agency, 2002, Current drinking water standards, national primary and secondary drinking water regulations: Washington, D.C., U.S. Environmental Protection Agency, accessed April 1, 2002, at URL http://www.epa.gov/safewater/ mcl.html/

U.S. Geological Survey, 1963-64a, Surface-water records of Arizona: U.S. Geological Survey report. 1963-64b, Ground-water records of Arizona: U.S. Geological Survey report. 1965-74a, Water-resources data for Arizona- Part 1, Surface-water records: U.S. Geological Survey Water-Resources Data Report.

1965-74b, Water-resources data for Arizona- Part 2, Ground-water records: U.S. Geological Survey Water Resources Data Report.

1976-83, Water-resources data for Arizona, water years 1975-81: U.S. Geological Survey Water Resources Data Reports AZ-75-1 to AZ-81-1.

1978, Progress report on Black Mesa monitoring program-1977: U.S. Geological Survey Open-File Report 78-459, 38 p.

Waterstone Environmental Hydrology and Engineering, Inc., (formerly Brogan-Johnson Consultants, Inc.), 1995, Evaluating the reliability of input parameters and their influence on model predictions using MODFLOWPUSGS N-aquifer flow model, Black Mesa, Arizona: Boulder, Colorado, Waterstone Environmental Hydrology and Engineering, unpaged.

White, N.D., and Garrett, W.B., 1984, Water resources data for Arizona, water year 1982: U.S. Geological Survey Water-Data Report AZ-82-1, 440 p.

1986, Water resources data for Arizona, water year 1983: U.S. Geological Survey Water-Data Report AZ-83-1, 387 p.

1987, Water resources data for Arizona, water year 1984: U.S. Geological Survey Water-Data Report AZ-84-1, 381 p.

1988, Water resources data for Arizona, water year 1985: U.S. Geological Survey Water-Data Report AZ-85-1, 343 p.

Wilson, R.P., and Garrett, W.B., 1988, Water resources data for Arizona, water year 1986: U.S. Geological Survey Water-Data Report AZ-86-1, 341 p.

1989, Water resources data for Arizona, water year 1987: U.S. Geological Survey Water-Data Report AZ-87-1, 385 p.

Zhu, Chen, Waddell, R.K., Star, I., and Ostrander, M., 1998, Responses of ground water in the Black Mesa Basin, northeastern Arizona, to paleoclimatic changes during the late Pleistocene and Holocene: Geology, v. 26, no. 2, p. 127-130.

Zhu, Chen, 2000, Estimate of recharge from radiocarbon dating of groundwater and numerical flow and transport modeling: Water Resources Research, v. 36, no. 9, p. 2607-2620. 
Selected References 76 